\title{
جهود المكتبات الأكاديمية العربية في دعم أهداف التنمية المستدامة: دراسة وصفية تحليلية
}

\author{
د. محمد عبد المولمى محمود(•) \\ مدرس بقسم المكتبات والوثائق والمعلومات / كلية \\ الآداب - جامعة القاهرة
}

مستخلص:

اعتمدت الدراسة على المنهج الوصفي التحليلي مع استخدام أدوات جمع البيانات: الملاحظة، و الاستبيان، و المقابات الثخصية، واعتمدت الدر اسة على عينة عشو ائية من المكتبات الأكاديمية (مكتبات الجامعات و الكليات و المعاهد) عددها (7 1 ) مكتبة، وسعت الدر اسة لتحقيق ثلاثة أهداف هى: رصد وتحليل دور المكتبات الجامعية بمصر في دعم أهداف التنميـة المستـدامـة،ورصد وتحليل آر اء العاملين بالمكتبات و أعضاء هيئة التدريس بأقسام المكتبات في الجهود الواجب دهي على دهى المكتبات الأكاديمية تنفيذها لتحقيق أهداف التتمية المستدامة، و إعداد مقياس استرشادي لتقييم أداء جهود التتمية المستدامة بالمكتبات الأكاديمية بصفة خاصة وللمكتبات على اختلاف أنو اعها بصفة

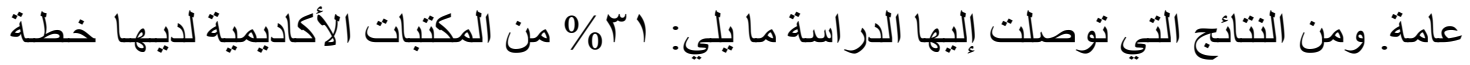

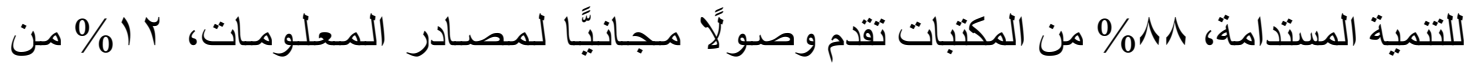
المكتبات تقدم خدمة رعاية الأطفال (حضانة) كخدمة مجتمعيـة لمجتمع المستفيدين منهـا، لا توجد علاقة بين نوع المكتبة وامتلاكها لخطة للتنمية المستدامة، يقوم الكثير من المكتبات

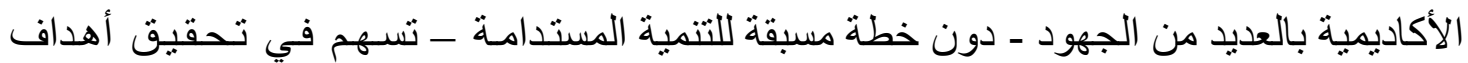
التنمية المستدامة، وفقًا لتقبيم أداء المكتبات باستخدام المنتوج التطبيقي للدر اسـة مقياس جهود

•rmm_abdelmawla@yahoo.com 
التتمية المستدامة في المكتبات (SoLSDE)، توز عت المكتبات على ثلاث فئات: مكتبات حصلت

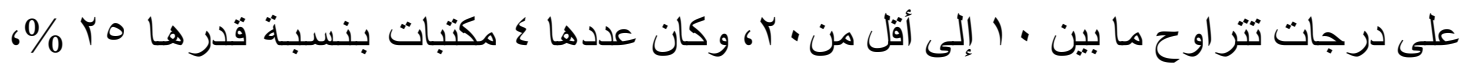

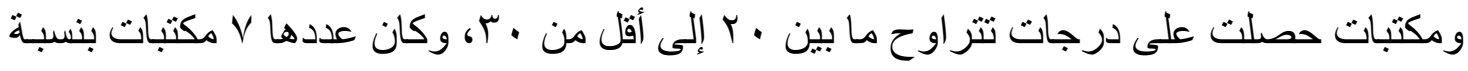

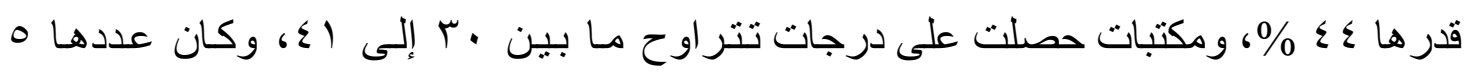

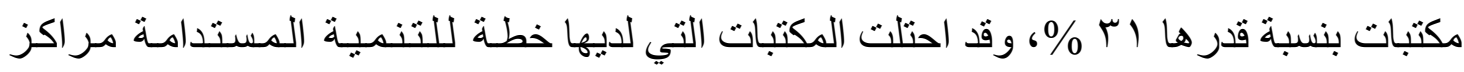
متقدمة. و أوصت الدر اسة بعدة توصيات، منها: أن تقوم المكتبات الأكاديمية بالبدء في تنفيذ و /أو

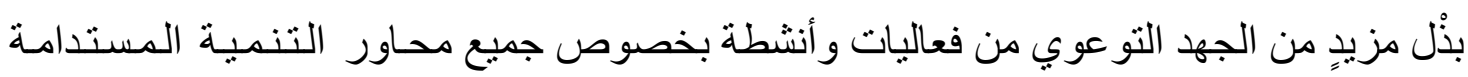

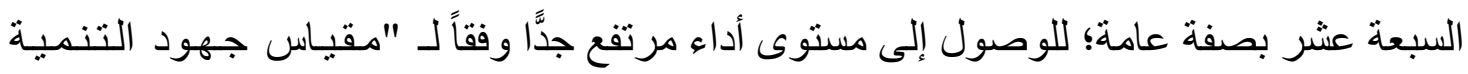
المستدامة في المكتبات"، تبني استخدام مصطلح - وفقًا للأدو ار و المهام الجديدة للمكتبة ـ "مركز للتنمية الثاملة" أو "مركز للتنمية المستدامة" على المكتبة الأكاديمية بصفة خاصة و أي مكتبـة بصفة عامة ـ بِساهم بشكلٍ فعالٍ في جميع محاور التنمية المستدامة.

\section{كلمات مفتاحية:}

التنمية المستدامة ـ المكتبات الأكاديمية العربية ـ المكتبات الجامعية فى مصر.

المقدمة

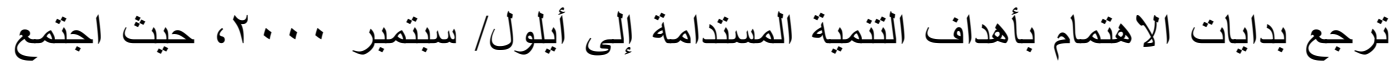
زعماء العالم في مقر الأمم المتحدة في نيويورك لمؤتمر قمة الألفية؛ من أجل اعتماد إعلان الأمم المان

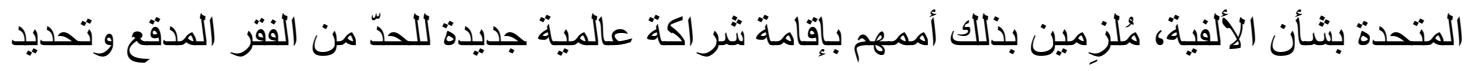

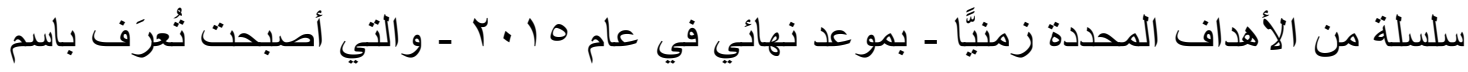
الأهداف الإنمائية للألفية،ثم قام مشروع الأمم المتحدة للألفية بتكليف من الأمين العام للأمم المتحدة في عام Y . . Y، بوضع خطة عملٍ ملموسة للعالم؛ من أجل تحقيق الأهداف الإنمائية للألفية و عكس اتجاه الفقر المدقع والجوع و المرض التي تؤثر على المليار ات من الناس. وفي عام ه . . ب، قدمت الهيئة الاستشارية المستقلة برئاسة البروفيسور جيفري دو د. ساكس توصياتها النهائية إلى الأمين العام معنونة بـ (الاستنمار في التنمية: خطة عملية لتحقيق الغايات الإنمائية للألفية)،

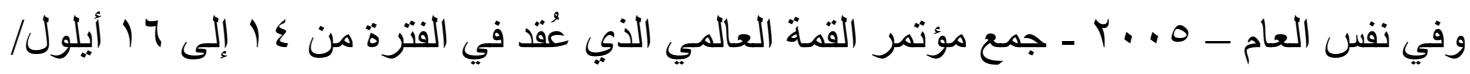

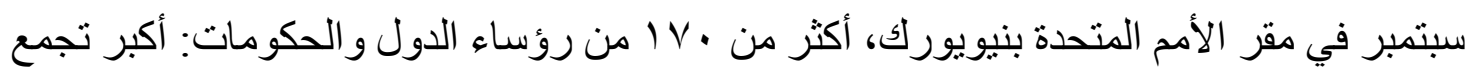

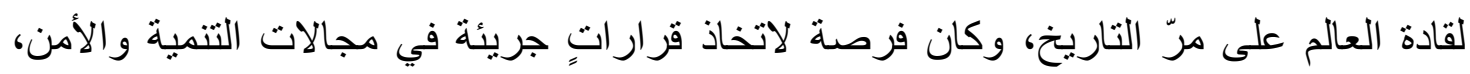
وحقوق الإنسان، وإصلاح الأمم المتحدة. وقام جدول الأعمال على مجموعة المقترحات الممكن تحقيقها، و التي بيّنها الأمين العام كوفي عنان في تقريره (الأمم المتحدة، 9 ( • ب). 
وفي 1 . . r،اجتمعت حكومات ومؤسسات و أعمار تجارية و عددُ من مجموعات المجتمع المدني حول الدعوة إلى اتخاذ إجراءات لخفض الفقر والجوع و المرض بحلول عام 0 ــr، بإعلان التزامات لتحقيق الأهداف الإنمائية في الألفية، في مناسبة رفيع المستوى بمقر الأمم المتحدة في مب أيلول/ سـبتمبر، وقال الأمين العام للأمم المتحدة في نهاية المناسبة التي امتدت ليوم كامل، و عقدها مع رئيس الجمعية العامة ميغيل ديسكوتو، أن المناسبة "فاقت أكثر توقعاتنا

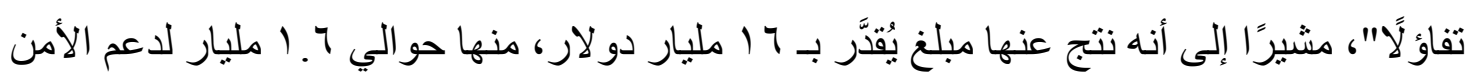

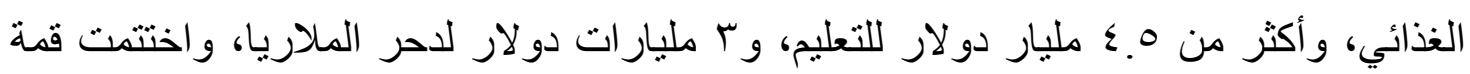

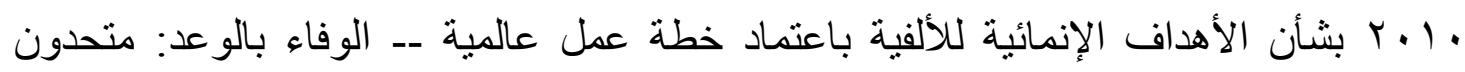

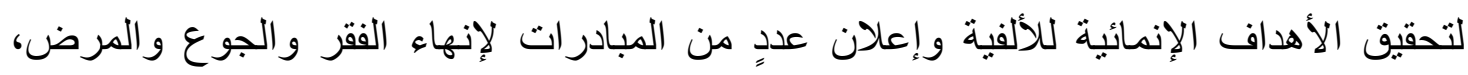

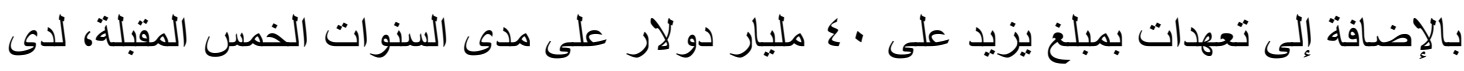

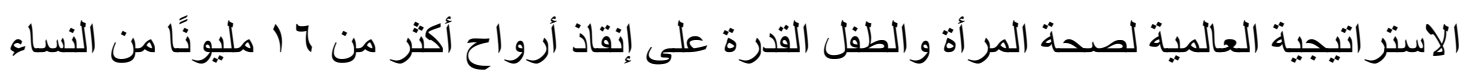

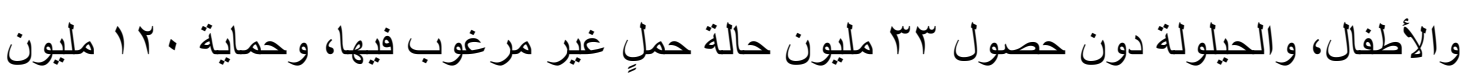

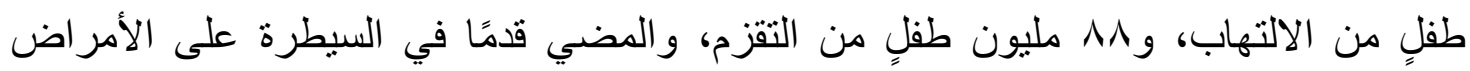
الفتاكة، مثل: الملاريا وفيروس نقص المناعة البشرية/الإيدز، وضمان وصول النساء و الأطفال

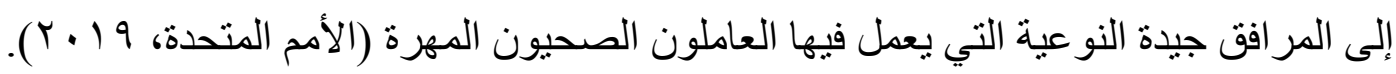

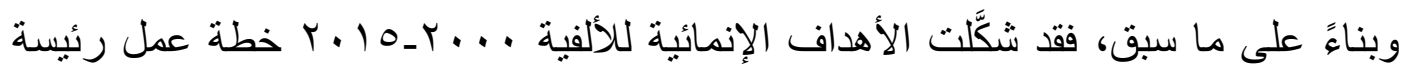
للدول النامية و الأقل نموًا؛ للانتقال إلى عالٍٍ جديدٍ يرتكز على منظومة عملٍ دولية تهدف إلى إنهاء الفقر المدقع، والذي يُعدُّ أحد الأسباب التي يترتب عليها تهميش وتدهور الأوضـاع الاجتماعية للدول التي تقع شعوبها تحت وطأة الفقر؛ لذلك حثدت المنظمات الدولية جهودًا غير مسبوقة لتحقيق هذه الأهداف، وباقتر اب انتهاء السنوات الخمس عشرة المقررة لتنفيذ الأهداف الإنمائية للألفية، ظهرت الحاجة إلى استراتيجية عالمية جديدة تتسم بالثمولية، حيث توصلت الدول الأعضاء بالأمم المتحدة إلى بناء خطة للتنمية المستدامة بعنوان "تحويل عالمنا"،على أن يكون

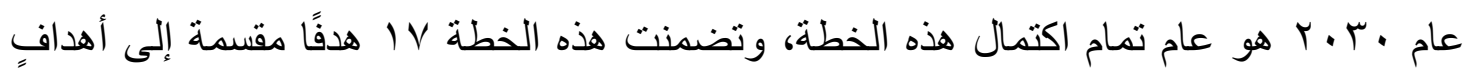

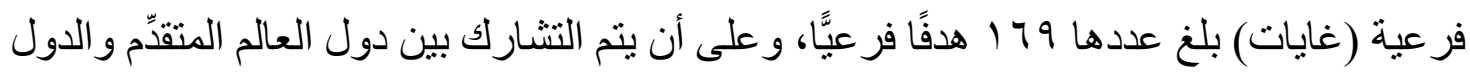
المتوسطة النمو والأقل نموًا لتحقيق هذه الأهداف والغايات (الجهاز المركزي للتعبئة العامة والإحصاء المصري، 9 (1) ( ).

ويرى البعض أن مهمة تحقيق أهداف التتمية المستدامة تقع على عاتق الحكومات فقط،و الصحيح أنها مهمة المجتمع بجميع عناصره من مؤسساتٍ وافراد، نعم يقع على الدولة 
نصيبٌ أكبر من توعية ودعم مادي ومعنوي لجميع مكونات المجتمع التي ينبغي أن يشارك كلّ منها بحسب قدرته وتخصصه ومجاله.

ومن ثمَّ قد شر عت الحكومات العربية في الاهتمام بالتتمية المستدامة وكيفية تحقيق أهدافها،

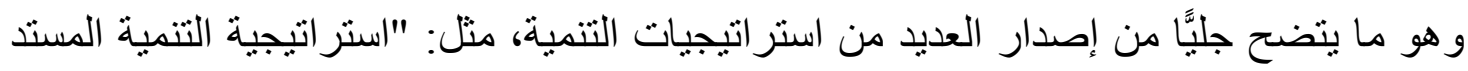

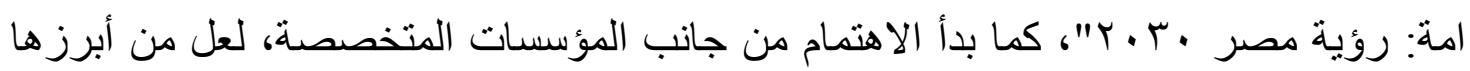

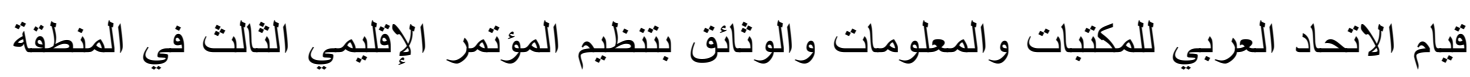

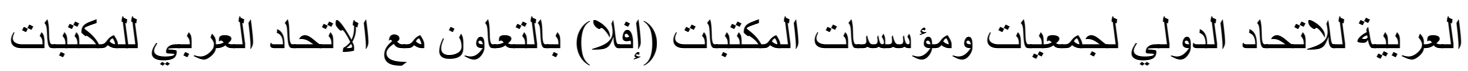

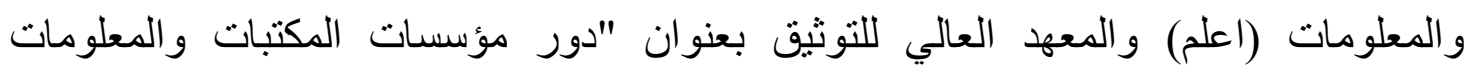

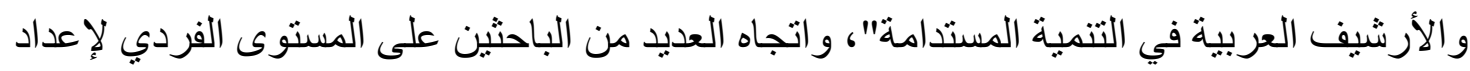

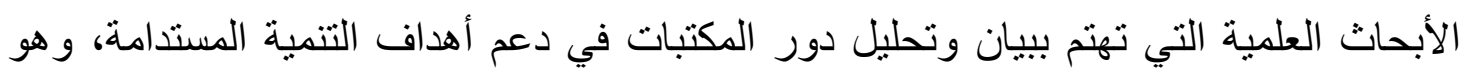
محل اهتمام الدراسة الحالية أيضًا تركيزًا على الدكتبات الأكاديمية.

\section{مشكلة وأهمية الدراسة}

لاحظ الباحث من خلال تصفحه للإنتاج الفكري حول الموضوع أنهيركز على المكتبات

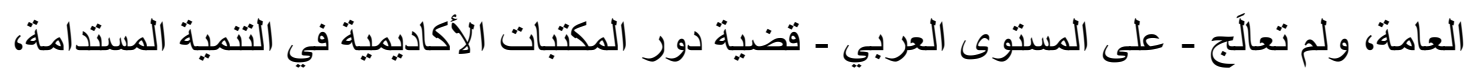

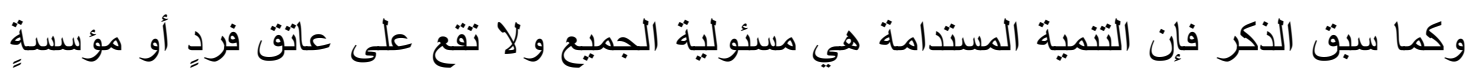

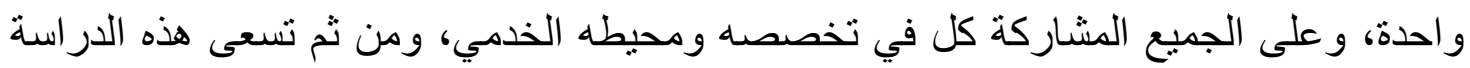

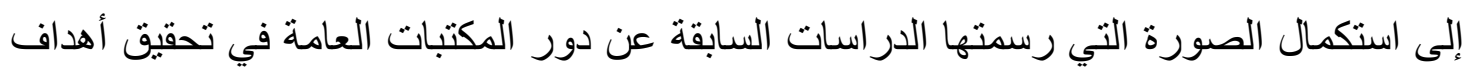
التنمية المستدامة بإيضاح دور المكتبات الأكاديمية في هذا الثأن. ولأن البحث العلمي يعتمد على البناء على ما وصل إليه السابقون وما يقترحونه من دئه

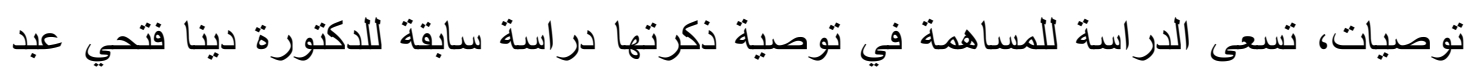

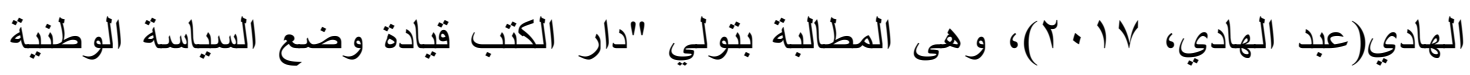

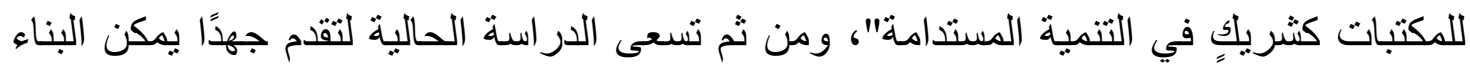

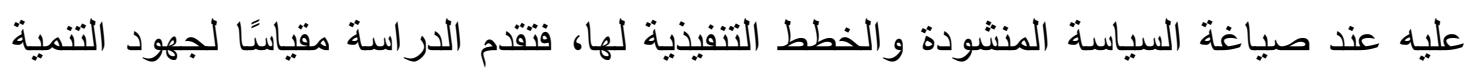
Scale of Libraries Sustainable Development Efforts المستدامة في المكتبات الفياتة (SoLSDE)

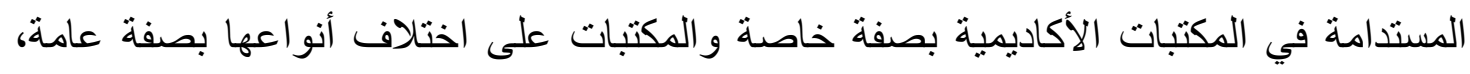

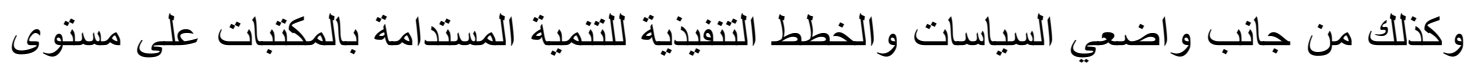
الدولة، إضافة إلى إمكانية استخدامه كأداةٍ للتقبيم. 


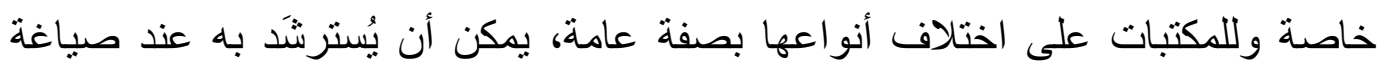

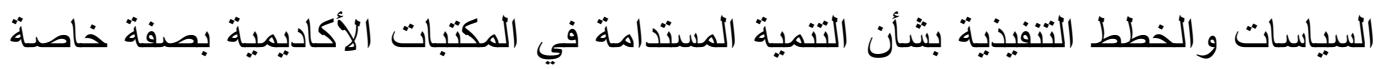
و المكتبات على اختلاف أنو اعها بصفة عامة، وكذلك من جانب و اضعي السياسات و الخطط

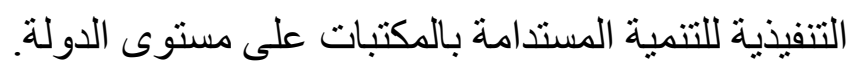

\section{تساؤلات وفروض الاراسة}

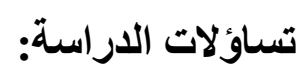

$$
\text { تسعى الدر اسة للإجابة عن التساؤ لات التالية: }
$$

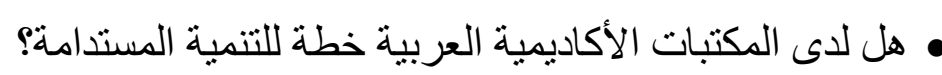
• ما أوجه الجهود التي تتم من جانب المكتبات الأكاديمية حاليًا وفق الاستبيان المعروض عليهي التهم

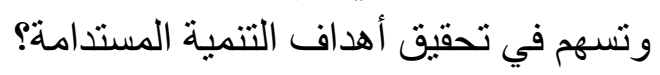
• ما أوجه الجهود التي تتم من جانب المكتبات الأكاديمية حاليًا ولم تكن ضمن الاستبيان

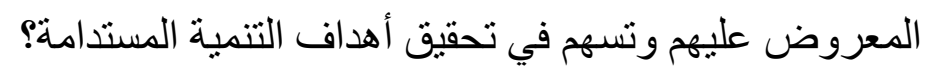

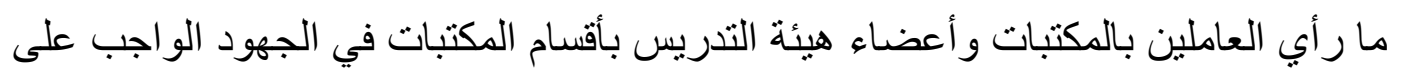

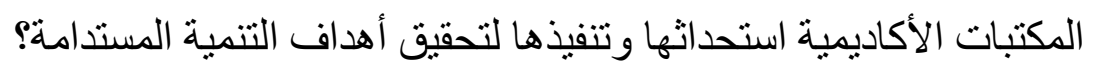
فروض الاراسة:

تسعى الدر اسة للتحقق من الفروض الاهن التالية: • معظم المكتبات الأكاديمية العربية ليس لديها خطة للتنمية التروفية المستدامة. • هنالك علاقة بين نوع المكتبة و امتلاكها لخطة للتنمية المستدامة.

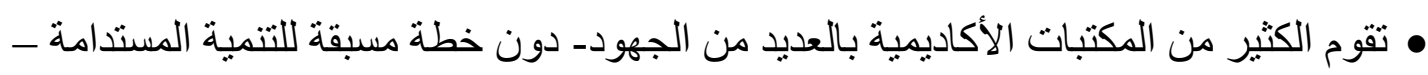
تسهم في تحقيق أهداف التنمية المستدامة. منهج الدراسة وأدواتها

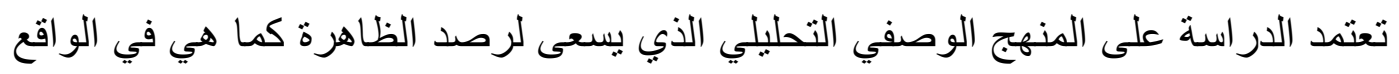

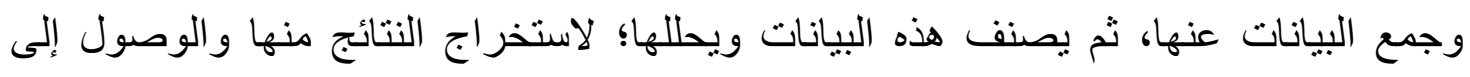


استنتاجاتٍ تساعد في فهم الو اقع وتطويره، وتتمثل أدوات جمع البيانات في: الملاحظة، والاستبيان

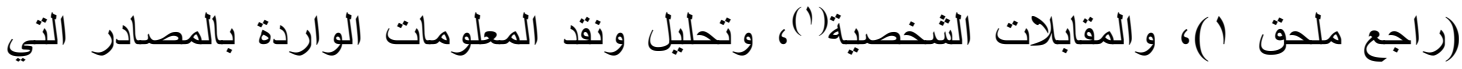

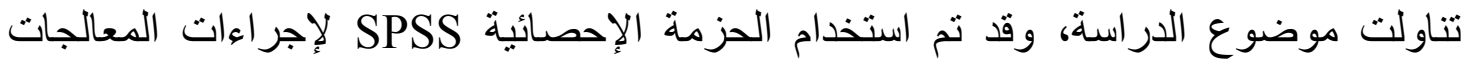

اعتمدت الدراسة على عينة عشو ائية من المكتبات الأكاديمية (مكتبات الجامعات والكليات

و المعاهد) عددها (7 أمن ) مكتبة.

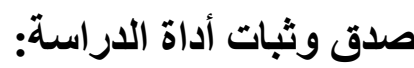

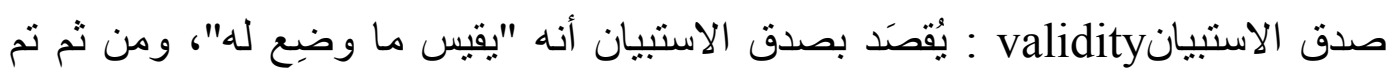

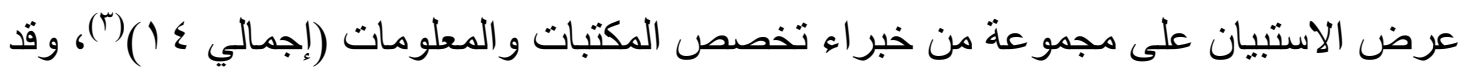

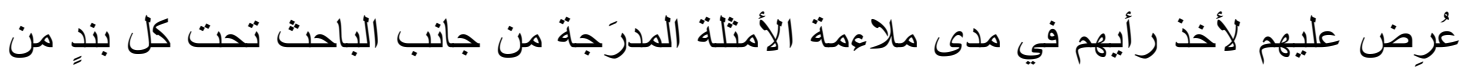

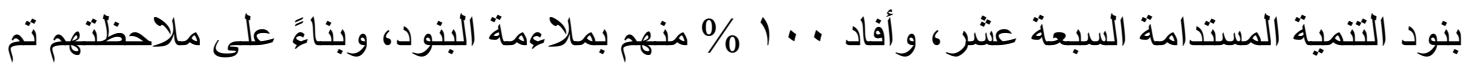

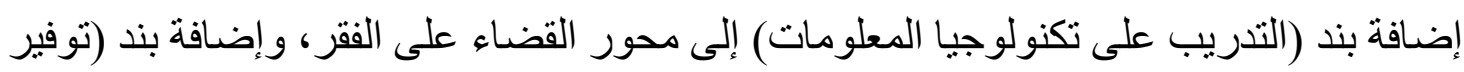

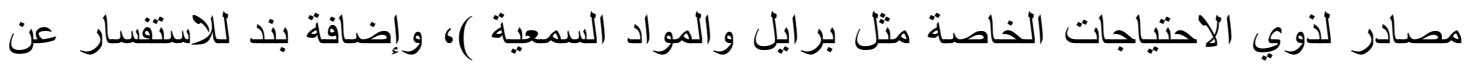

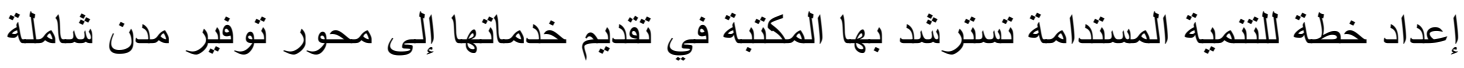

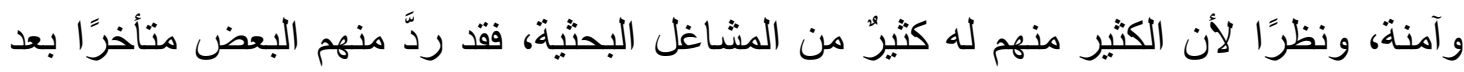

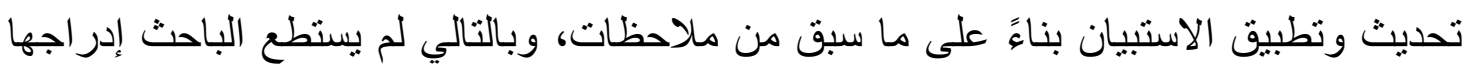

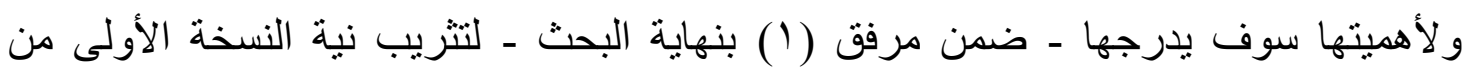
المنتوج التطبيقي للار اسة "مقياس جهود التنمية المستدامة في المكتبات"

اـ ـ تم توزيع الاستبيان على جميع المكتبات بشكل الكتروني باستخدام خدمة google forms بينما تم اخذ الإجابة

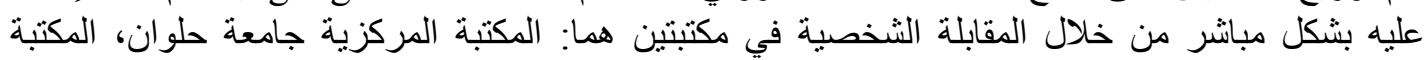

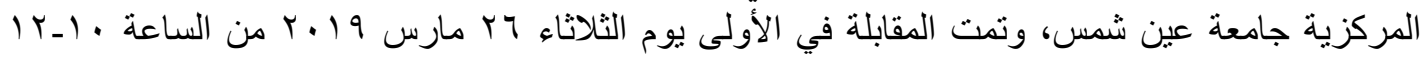

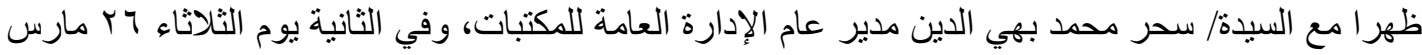

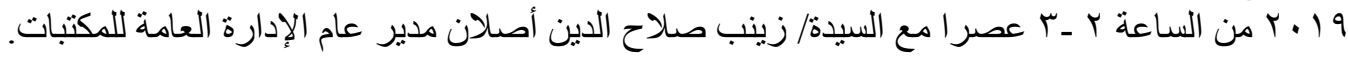

2- IBM Corp. Released 2017. IBM SPSS Statistics for Windows, Version 25.0.

Armonk, NY: IBM Corp.

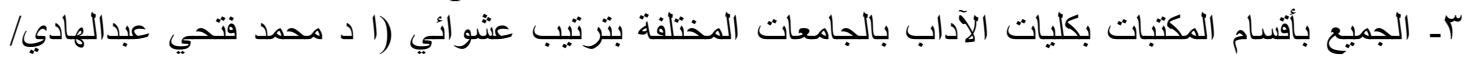

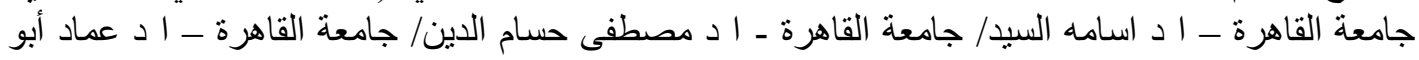

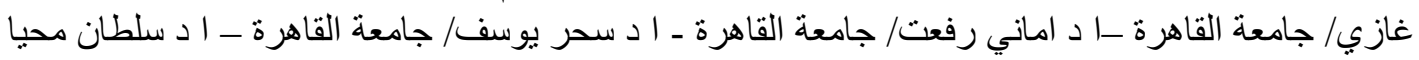

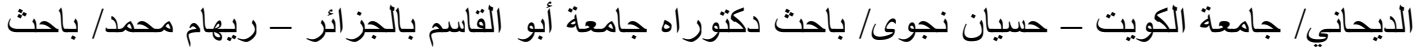

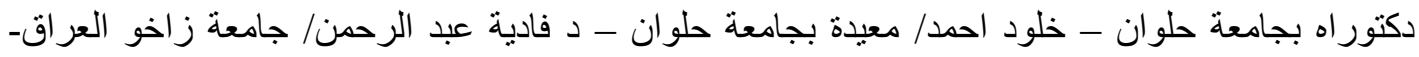

سميرة احمد/ مدرس مساعد بجامعة القاهرة). 
ثبات الاستبيان reliability: ويُقتصند به أنه لا يناقض نفسه أي محتوياته متسقة مع الهدف

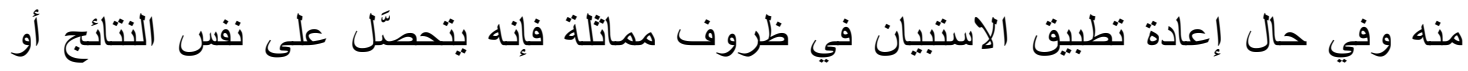

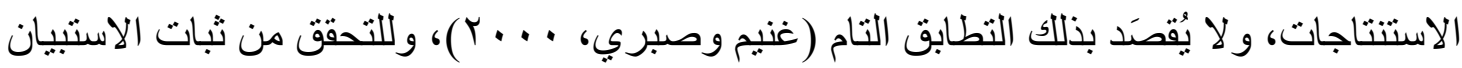

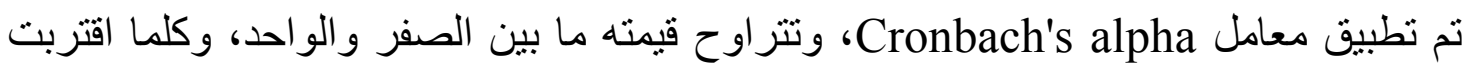

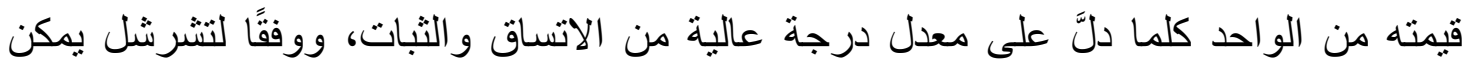

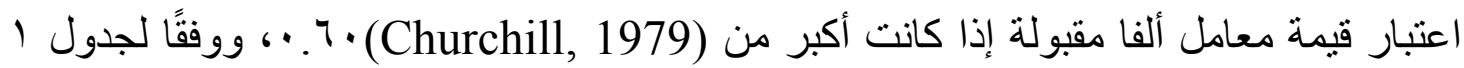
فإن الاستبيان يتمتع بدرجة اتساقٍ وثباتٍ عالية(').

جدول اقيمة معامل ألفا

\begin{tabular}{|c|c|}
\hline \multicolumn{2}{|c|}{ Reliability Statistics } \\
\hline Cronbach's Alpha & N of Items \\
\hline Ars. & $\mathrm{V}$. \\
\hline
\end{tabular}

حدود الدراسة:

الحدود الموضو عية: رصد وتحليل جهود المكتبات في دعم أهداف التنمية المستدامة. الحدود المكانية: الدول العربية.

الحدود النو عية: المكتبات الأكاديمية (مكتبات الجامعات ومكتبات الكليات و المعاهد العليا)(؟).

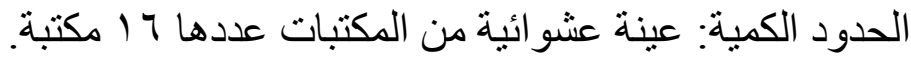

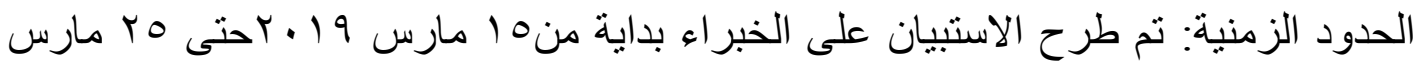

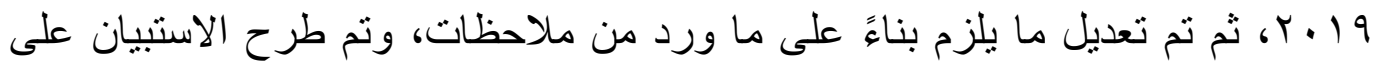

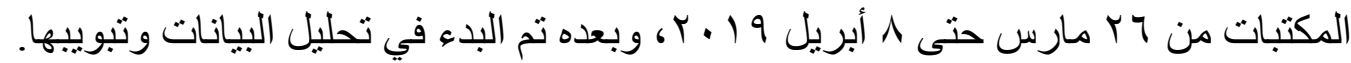

(1) في الجدول رقم ا يمثل الرقم •V عدد العناصر (الأسئلة) التي يتضمنها الاستبيان تحت محاور التنمية المستدامة السبعة عشر بدون الأسئلة المفتوحة.

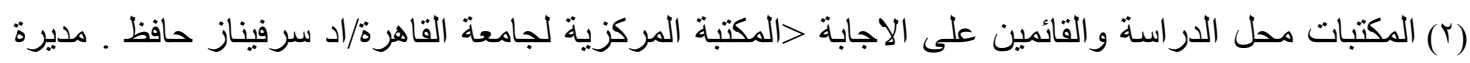

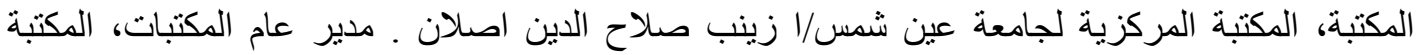

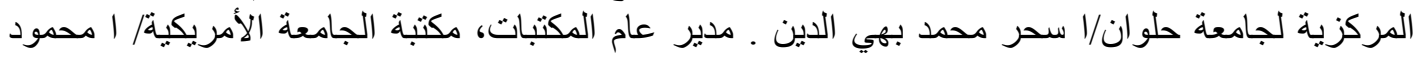

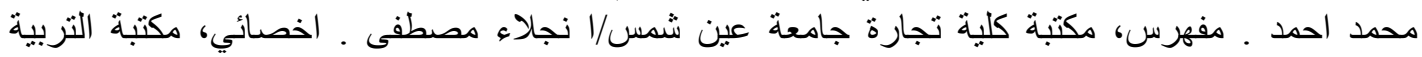

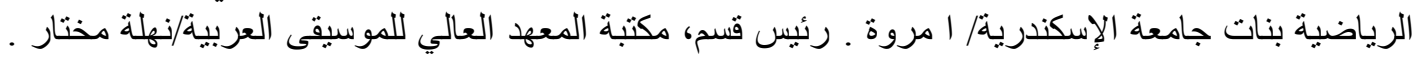

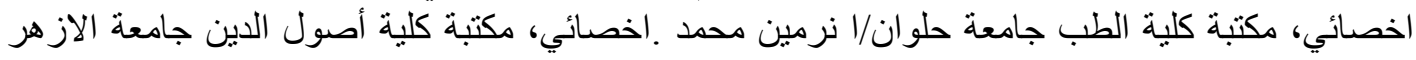

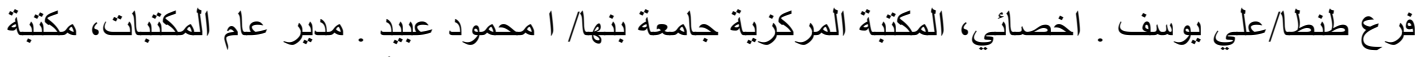

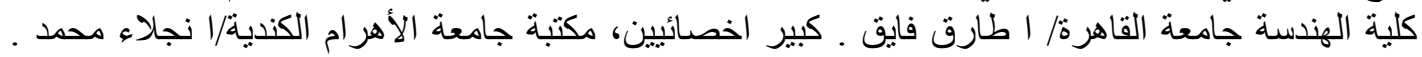

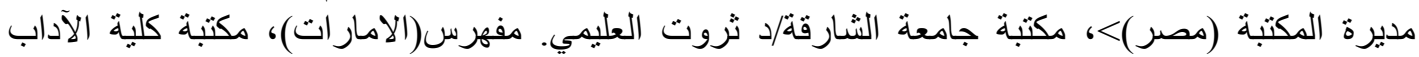

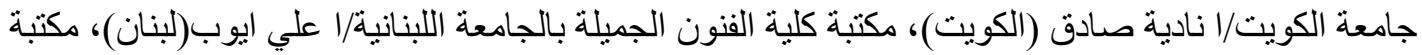

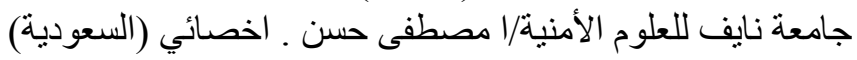




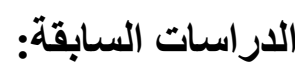

أكدت أماني حمارشة (حمارشة، ب ( ب ب) في در استها على أن للمكتبات بأنو اعها المختلفة دورًا كبيرًا في تنمية المجتمع في مختلف المجالات الثقافية و الفكرية و الاجتماعية ... إلخ، ويبرز

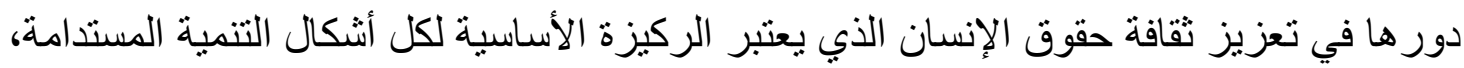

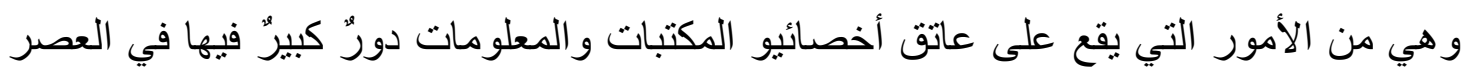
الذي أصبح لا بد من تبني إدارة التغبير في مختلف الممارسات و العمليات و الخدمات التي تقدمها، و أكدت أن للمكتبات الأكاديمية إسهامًا لا يمكن إنكاره في تقوية وترسيخ دعائم حقوق الإنسان وتفعيل دور المؤسسة التي يوجد فيها في هذا المجال، ومن ثم تحاول هذه الورقة إبراز الدور المهم الذي تلعبه المكتبة الأكاديمية في تعزيز ثقافة حقوق الإنسان، مع تسليط الضوء دوعة على تجربة

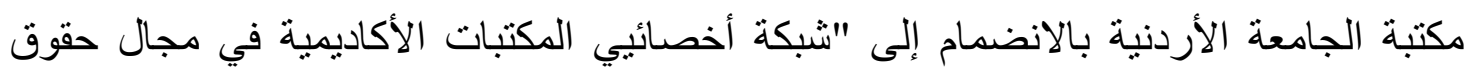
الإنسان في منطقة الثرق الأوسط و شمال إفريقيا". وذللك في إطار البرنامج الإقليمي لمعهد

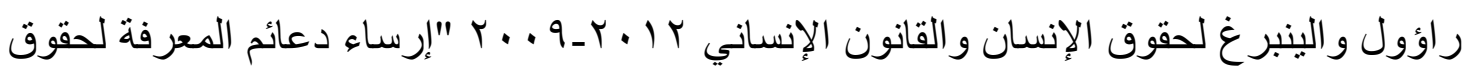
الإنسان ومصادر ها في الثرق الأوسط وشمال إفريقيا". كما استعرضت فو ائد هذه المشاركة و الأنشطة المتنوعة التي قامت بها الثبكة، كما أبرزت أهم التحديات التي واجهت تحقيق أهداف المشروع وما زالت تو اجهه، وتتفق هذه الدراسة مع الدراسة الحالية في الاهتمام بدور المكتبات الجامعية في التنمية، وإن اختلفت في وجهة النظر حيث اهتمت بمجال حقوق الإنسان.

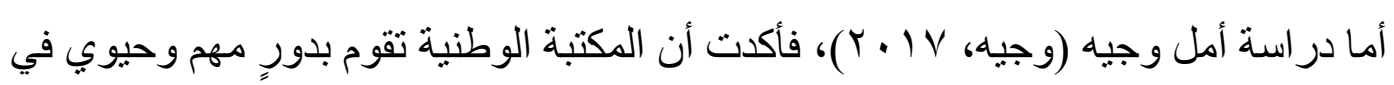
تحقيق أهداف التنمية المستدامة على مستوى الدولة، وذللك من خلال أدائها لوظائفها الرئيسة، وخاصة تللك المتعلقة بجمع التراث الفكري الوطني والتعريف به وحمايته، وتقديم الخدمات المكتبية والمعلوماتية إلى جانب الإشراف على بعض المكتبات الأخرى داخل الدولة، وفي هذا الإطار قامت الباحثة بتقديم دراسة حالة لجهود واحدة من أبرز المكتبات الوطنية في العالم العربي، وهي مكتبة الملك فهد الوطنية من حيث إسهامها في تحقيق أهداف التنمية المستدامة في الدولة، وذلك في إطار التوجهات و الأهداف التي اشتملت عليها رؤية المملكة العربية السعودية • . . . ، موضحة الأنشطة و المبادرات سواء التي يتم تنفيذها بالفعل أو تلك المخطط لتنفيذها مستقبلً؛ بهدف تقييم الأنشطة و المبادر ات التي توفرت عليها المكة المكتبة واستشر اف مدى فعاليتها في تحقيق تلك أهداف التنمية المستدامة، وقد اعتمدت الباحثة على منهج دراسة الحالة بالأساس للتعرف على جهود مكتبة الملك فهد الوطنية في هذا الصدد، إلى جانب الاستعانة بمنهج تحليل

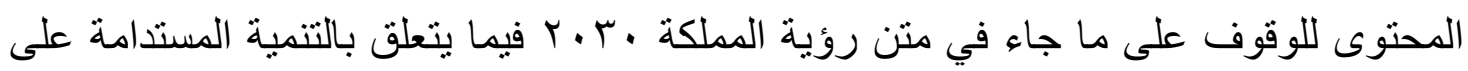
مستوى الدولة، و إبراز كيف يمكن أن تساهم المكتبة الوطنية في هذا الصدد، وقد تم الاستعانة 
بقائمة مراجعة إلى جانب المقابلة سواء المباثرة أو الإلكترونية كأدواتٍ لجمع البيانات. وقد

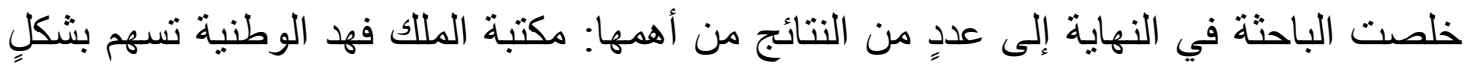
فعَّال في تحقيق أهداف التتمية المستدامة، ومن أهم التوصيات: أن تتبنى مكتبة الملك فهر مفهومًا

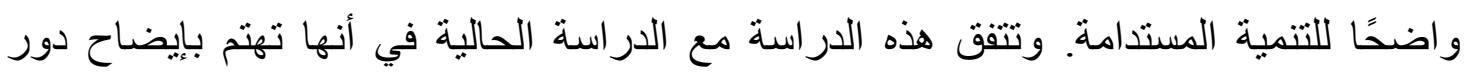

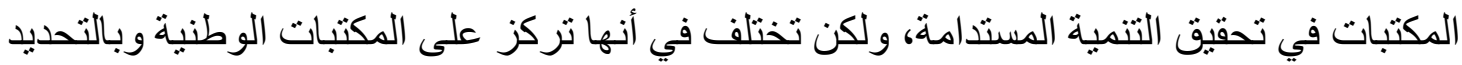
على مكتبة واحدة، بينما تركز الدراسة الحالية على المكتبات الأكاديمية من خلال عينة منها. (Ezeani, Ukwoma, Gani, Igwe, \& Agunwamba, بينما ناقشت دراسة إيزيني (2017 وآخرون المر افق والخدمات المتاحة لتقديم التعليم الجيد الثامل و العادل للطلاب ذوبي

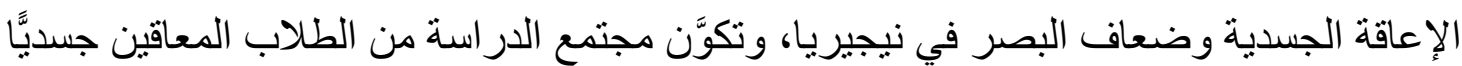

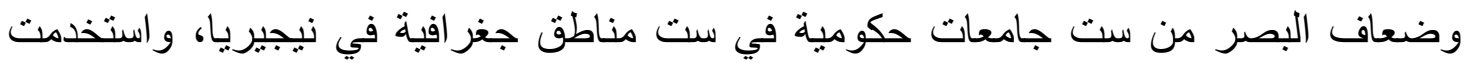

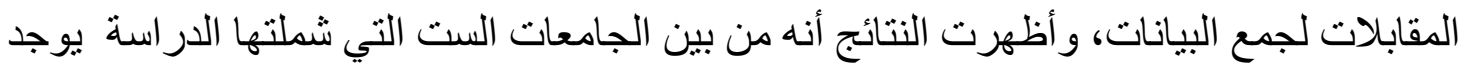

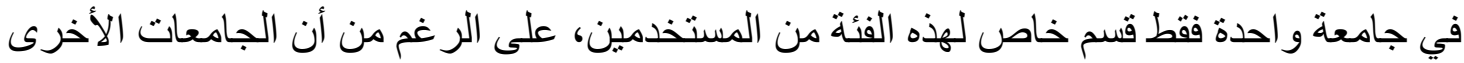

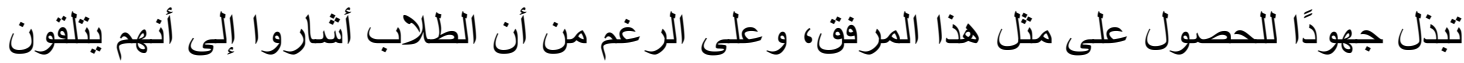

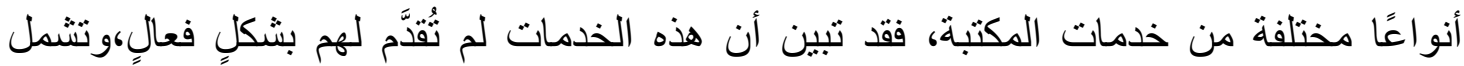

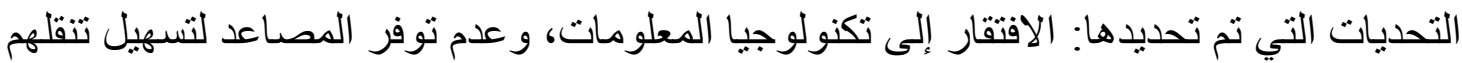

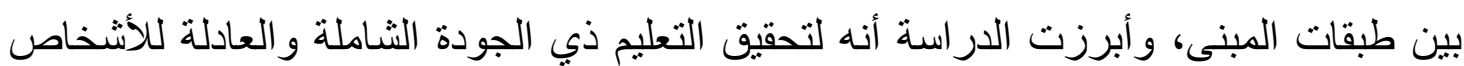

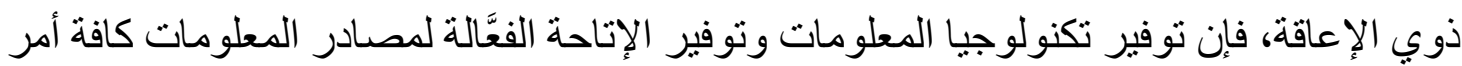

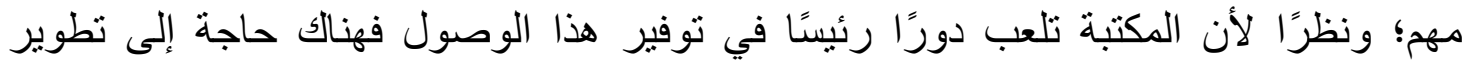

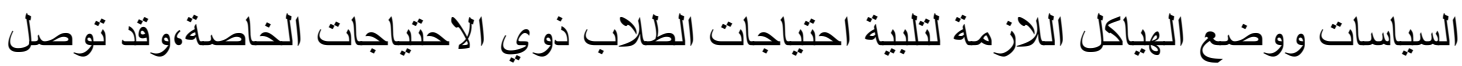
الباحثون إلى اقتر اح نموذج للوصول الثشامل إلى المعلومات للطلاب ذوي الاحتيات الاحتياجات الخاصة

(Ezeani, Ukwoma, Gani, Igwe, \& Agunwamba, 2017).

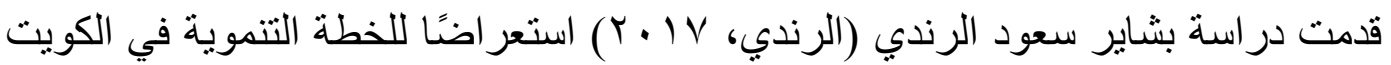

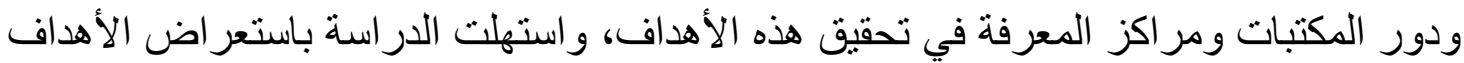

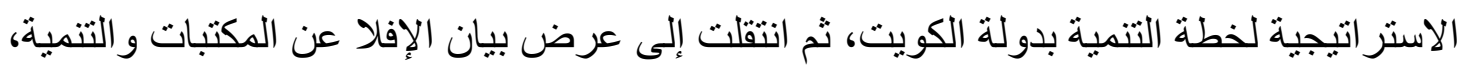

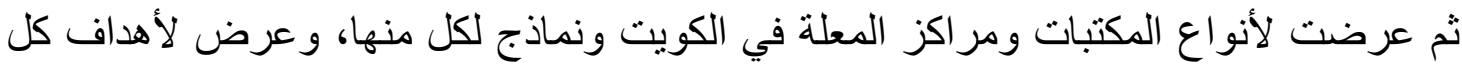

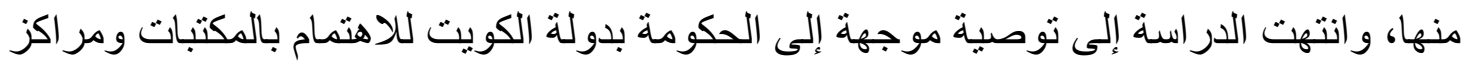

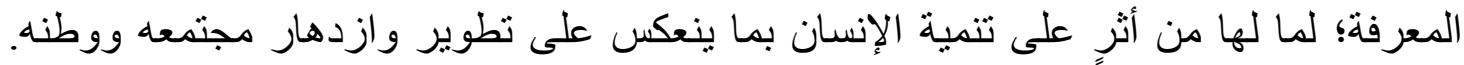

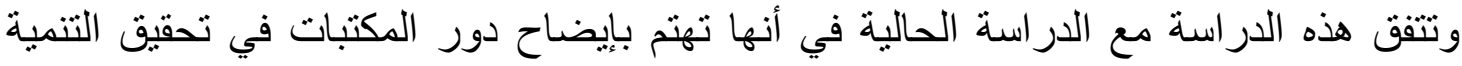
المستدامة، ولكن تختلف في أنها تركز على مر افق المعلومات بصفة لإنة عامة، بينما تركز الدراسة الحالية على المكتبات الأكاديمية من خلال عن عينة منها. 
في حين قدمت دراسة دينا محمد فتحي عبد الهادي (عبد الهادي، IV) و وصفًا وتحليلً للخدمات والأنشطة التي تقدمها مؤسسات المكتبات والمعلومات المصرية؛ من أجل تتفيذ أهداف التتمية المستدامة، واعتمدت الدراسة على المنهج الوصفي التحليلي، واستعرضت الدراسة الأهداف السبعة عثر للتنمية المستدامة، وركزت الدر اسة على وصف وتحليل و اقع الحال لدور

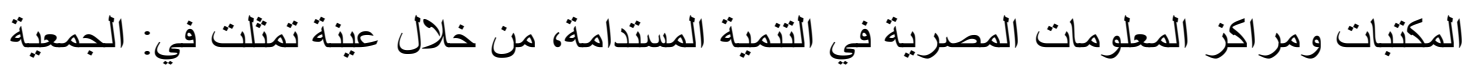
المصرية للمكتبات و المعلومات، و أقسام المكتبات، و المكتبات ومر اكز المعلومات، وبنك المعرفة

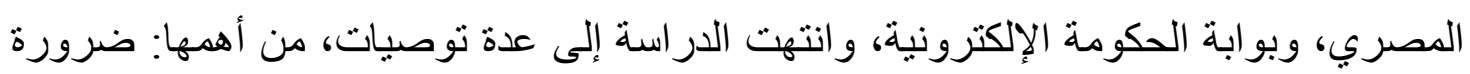
إعداد وثيقة تحدد دور قطاع المكتبات والمعلومات في تتفيذ التنمية المستدامة في مصر يعدها خبر اء التخصص. وتتفق هذه الدر اسة مع الدر اسة الحالية في أنها تهتم بإيضاح دور المكتبات في تحقيق التنمية المستدامة، ولكن تختلف في أنها تركز على مرافق المعلومات بصفة عامة، وفق عينة سبق ذكر ها بينما تركز الدراسة الحالية على المكتبات الأكاديمية من خلال عينة منها، كما تعتبر هذه الدر اسة نقطة انطلاق للار اسة الحالية فيما يتعلق بالتوصية المشار إليها، والتي تسعى الدر اسة الحالية للمساهمة في وضع لبنة مبدئية يمكن البناء عليها وتطوير ها من خلال تقديم أداة

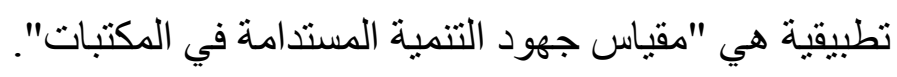

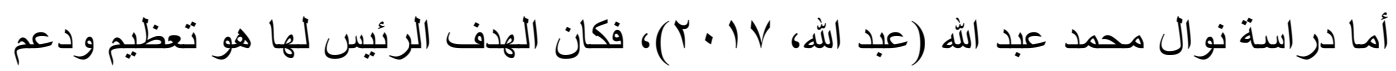
دور المكتبات العامة كمشارك في تحقيق أهداف التتمية من خلال طبيعة المهام والخدمات و الأنثطة التي تقدمها هذه المكتبات، إلى جانب هدفين فرعيين تمثنا في إلقاء الضوء على واقع المكتبات العامة من حيث الإمكانيات المادية و المقتنيات والقوى البشرية و الخدمات و الأنشطة؛ للكثف عن ما يمكن القيام به في تحقيق التنمية المستدامة، و إذكاء الوعي بتعريف التنمية

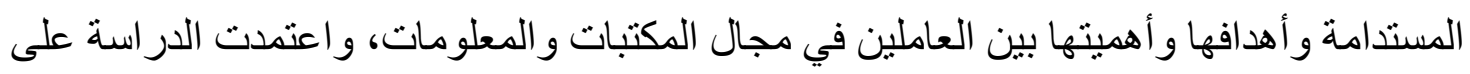

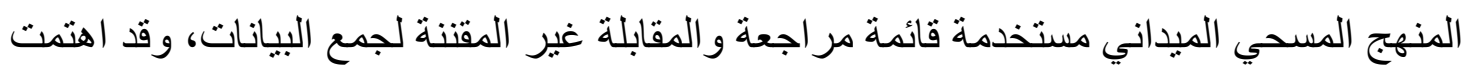

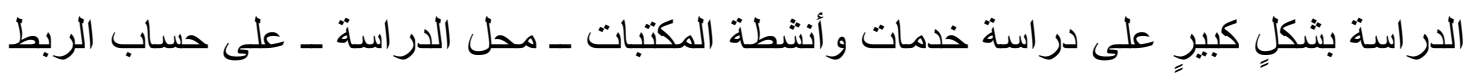
بين أنشطة المكتبات وأهداف التتمية المستدامة السبعة عشر ، وانتهت الدر اسة إلى عدة نتائج من أهمها: •0\% من المكتبات لا تسير في الطريق السليم كمساهٍِ في تحقيق أهداف التنمية المستدامة، وأكدت على عدة توصيات من أهمها: ضرورة توحيد جهة تبعية المكتبات العامة، العمل على زيادة ميز انية المكتبات العامة، و وتتفق هذه الدر اسة مع الدراسة الحالية في أنها تهنم بدور المكتبات في تحقيق التنمية المستدامة، ولكن تختلف في أنها اتخذت المكتبات العامة موضو عًا لها. 


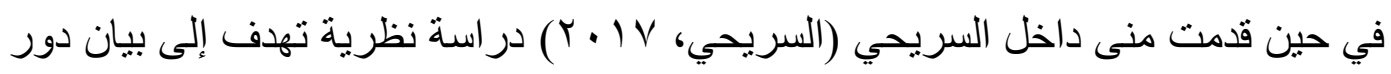

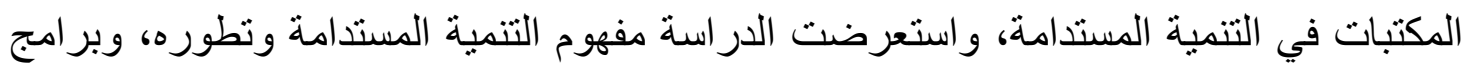

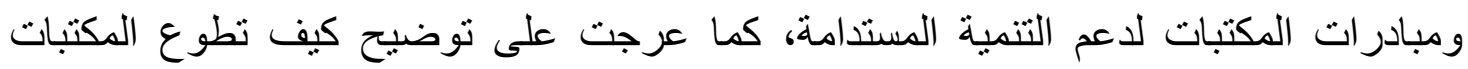

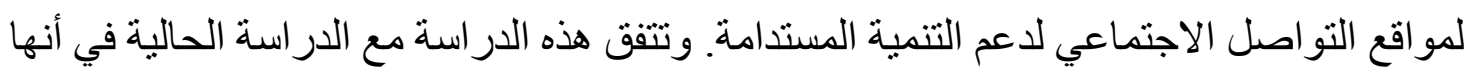

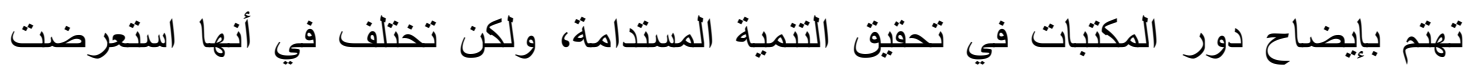

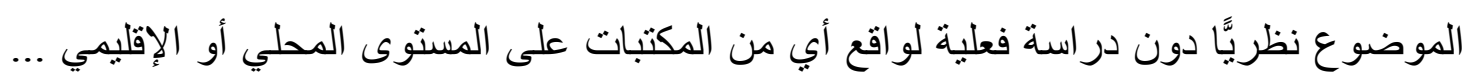

(Garcia-Febo, Kim, وفي مقالة انتترك فيها أكثر من خبير من خبر اء وباحثي المكتبات

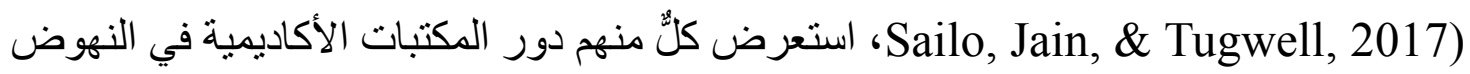
بأهداف التتمية المستدامة، أكد "لويدا غارسيا-فيبو" على أن المكتبات الأكاديمية والبحثية

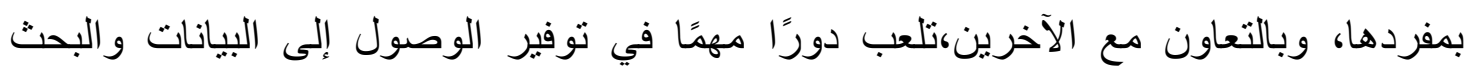

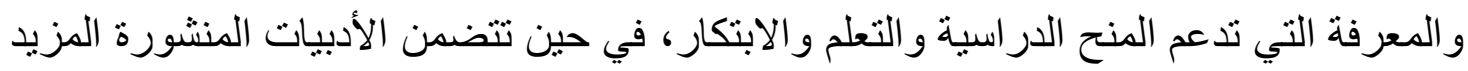

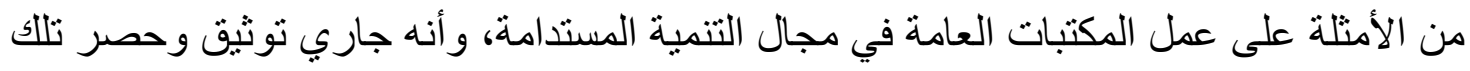

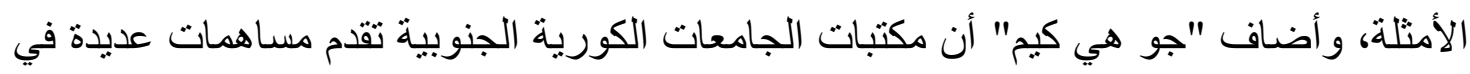

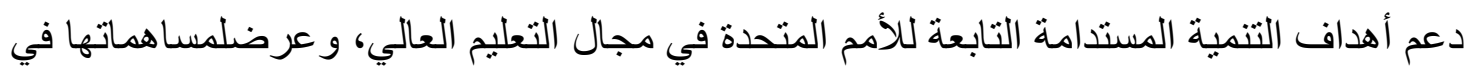

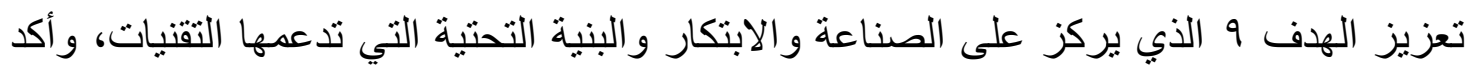

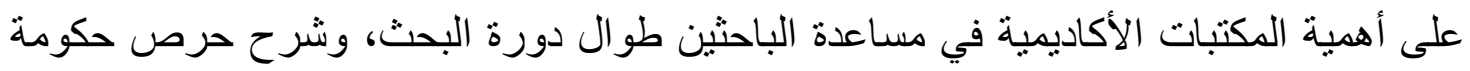

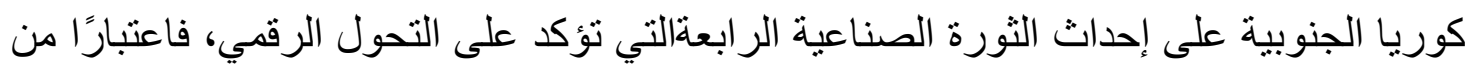

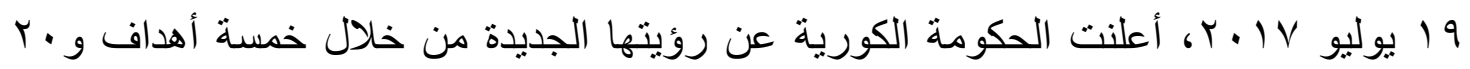

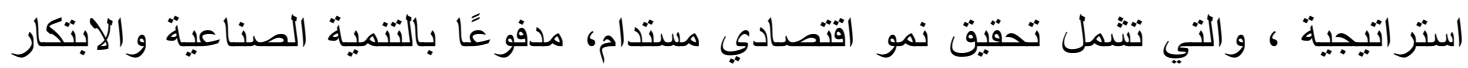

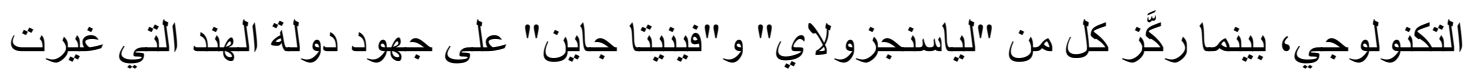

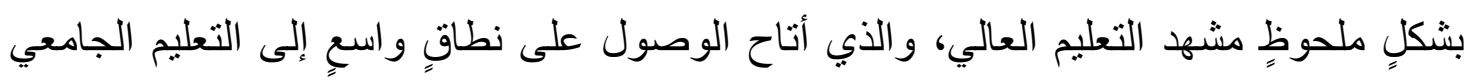

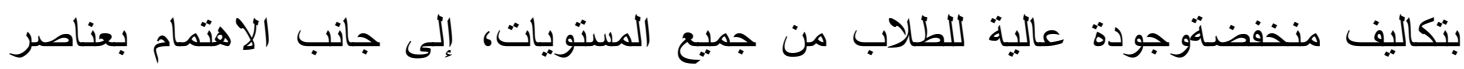

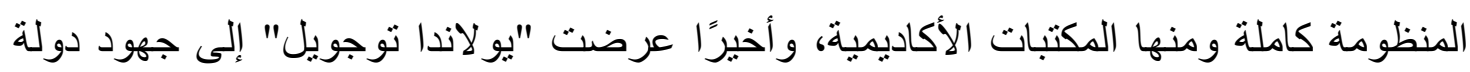

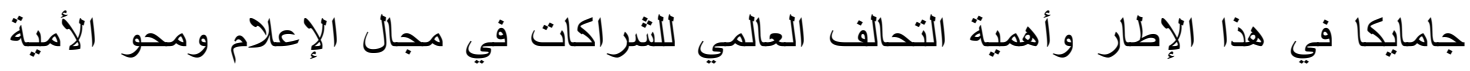

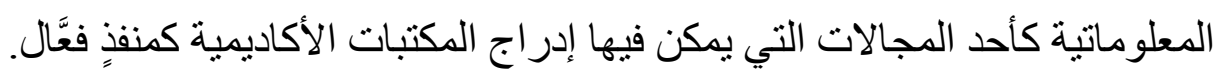

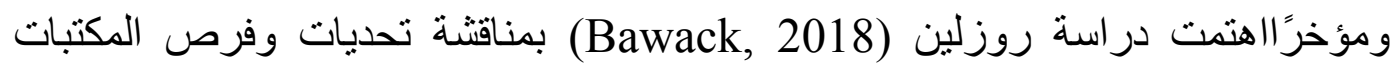

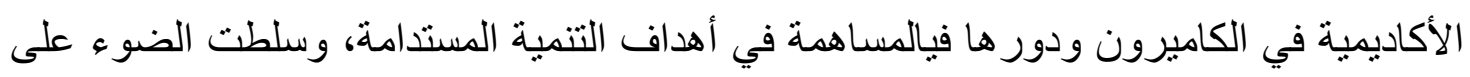


ما يمكن أن تفعله وما يجب عليهم فعله لدعم هذا العالم، كما تطرقت إلى عرض تأثير تكنولوجيا

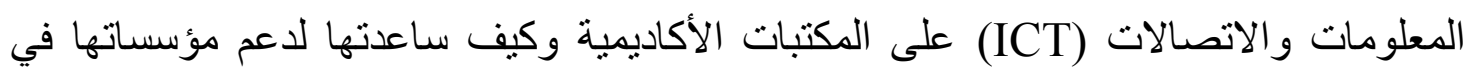

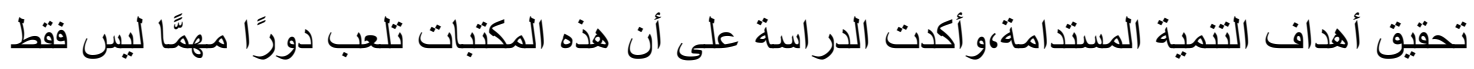

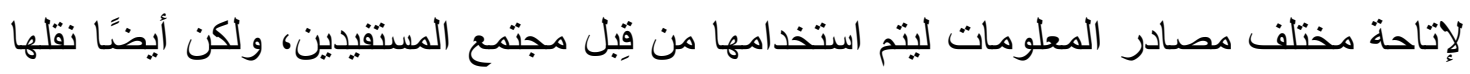

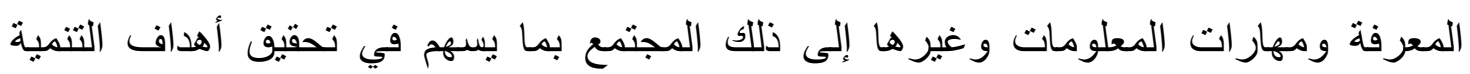

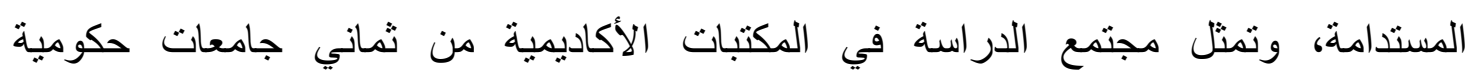

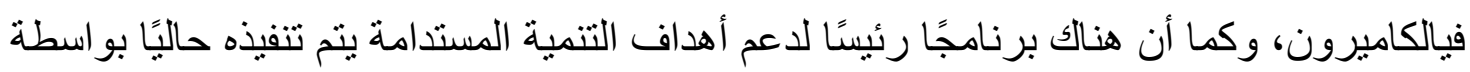

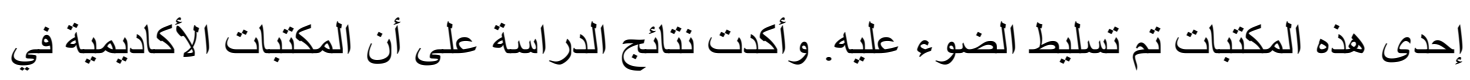

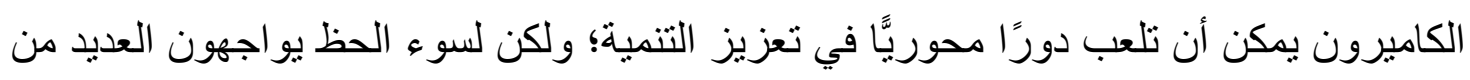

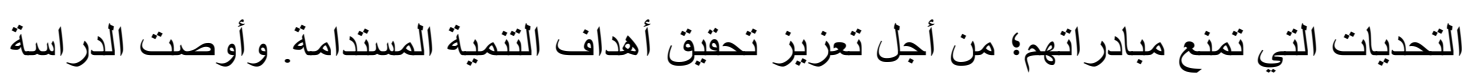

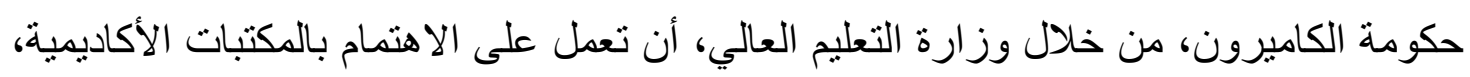

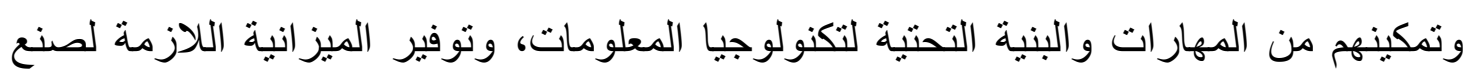
التأثنير المنشود.

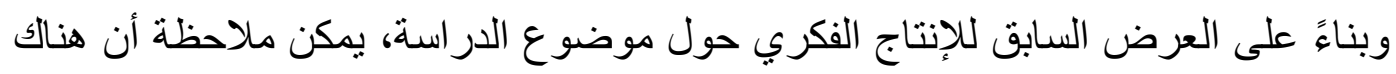

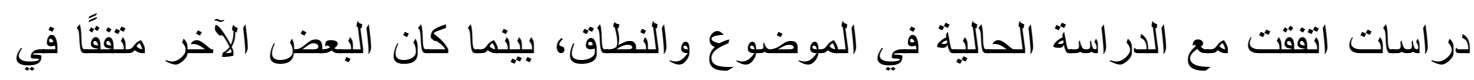

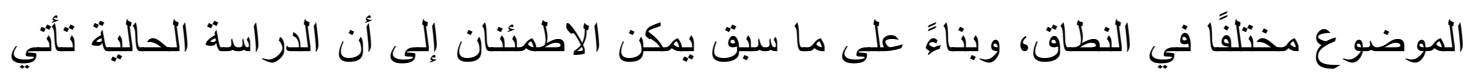

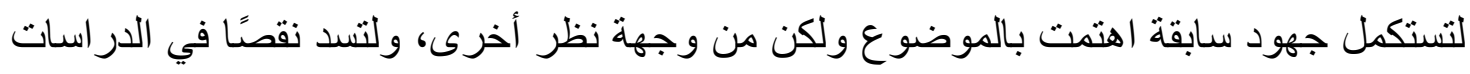

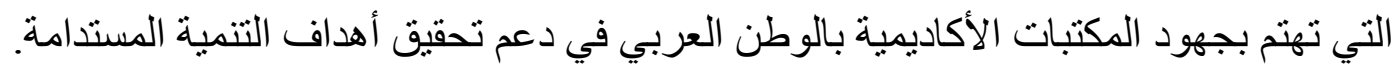

\section{النتائج والمناقشة}

• - مإعداد خطة للتنمية المستدامة:

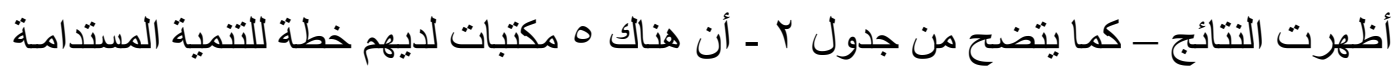

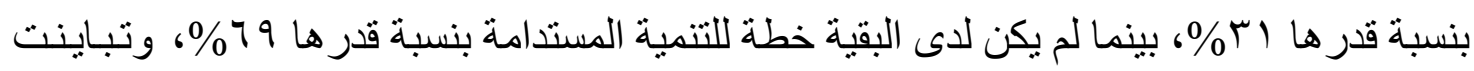

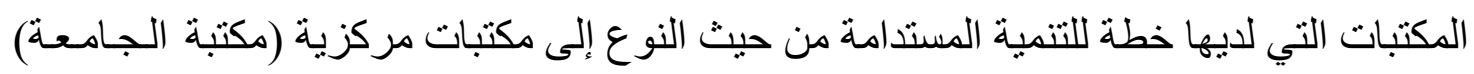

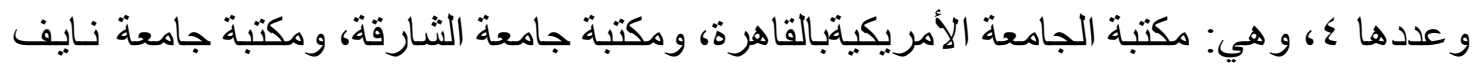

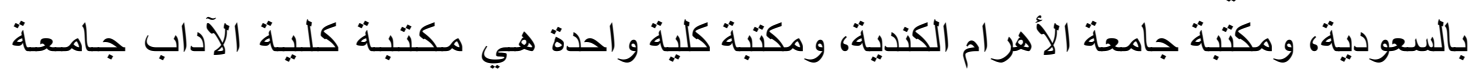

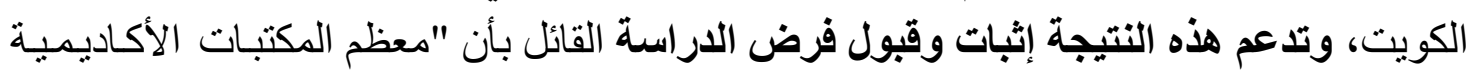

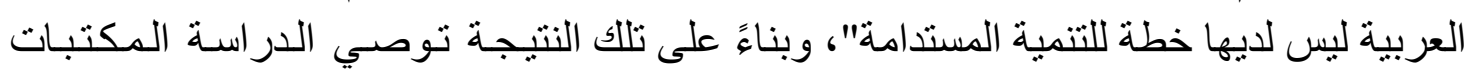
الاكاديمية بإعداد خطة للتنمية المستدامة. للتية. 


\section{جلول بتوزيع عدد المكتبات التي لايها خطة للتنمية المستدامة وفقً اللنوع}

\begin{tabular}{|c|c|c|c|c|}
\hline مجموع & كُعم & $\bar{\gamma}$ & نوع & متُفير \\
\hline$\wedge$ & $\varepsilon$ & $\varepsilon$ & مركزية & اعداد خطة للتتمية المستدامة \\
\hline$\Lambda$ & 1 & V & كلية & \\
\hline 17 & 0 & 11 & & مجموع \\
\hline
\end{tabular}

\section{ا - جهود القضاء على الفقر:}

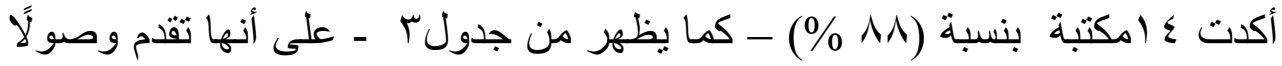

مجانيَّا لمصادر المعلومات، بينما أشارت مكتبتين بنسبة (1 Y \% \%) إلى تقديمهما خدماتهما بمقابل، وهما: المكتبة المركزية لجامعة القاهرة، ومكتبة كلية أصول الدين جامعة الأز هر ،حيث توجد رسوم منفصلة عن رسوم الدر اسة تُدَع لاستخدام المكتبة، و أكدت مكتبتان بنسبة (r M \%) على تقديمهما خدمة مجتمعية تمثلت في دار حضانة، هما: مكتبة جامعة الأهر ام الكندية، مكتبة جامعة الشارقة، ونفت ع ا مكتبة بنسبة (AN \% \%) تقديم هذه الخدمة،

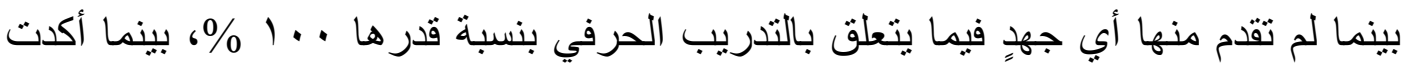
و احدة بنسبة قدر ها †\% على تقديم تدريب مهني مجاني هي المكتبة المركزية لجامعة القاهرة،

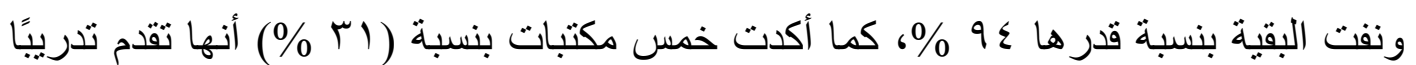
مجانيَّا على تكنولوجيا المعلومات، وهى مكتبة الجامعة الأمريكية، ونفت ذلك البقية بنسبة (99 \%): المكتبة المركزية لجامعة القاهرة، ومكتبة كلية التربية الرياضية، ومكتبة جامعة نايف، و مكتبة جامعة الأهر ام الكندية ولم يختر أي منهم "لا شيء مما سبق". وبناءً عليه توصي الدراسة المكتبات الاكاديمية بالاهتمام بتوفير تدريبٍ حرفي ومهني لمجتمع المستفيدين من الطلاب كأداة لهم على اكتساب المال، إلى جانب الثهادة العلمية التي سيحصل عليها من لن الجامعة، خاصة أن توفير فرصة عمل بالثهادة الجامعية يتضاءل في الظروف الاقتصادية على المستوى العالمي حاليًا، و الاهتمام بتوفير دار لر عاية الأطفال لمرتادي المكتبة، مع اتخاذ

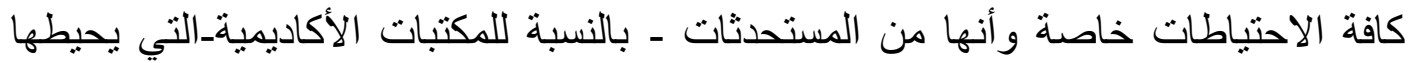
الكثير من المخاوف و المخاطر التي قد تمنع كثير من المكتبات من تنفيذها. 


\section{جدول ب توزيع أعداد المكتبات بثأن جهود القضاء على الجوع وفقً اللنوع}

\begin{tabular}{|c|c|c|c|c|}
\hline مجموع & نعم & ע & نوع & متغير \\
\hline$\wedge$ & V & 1 & مركزية & \multirow{2}{*}{ اتاحة مجانية } \\
\hline$\wedge$ & v & 1 & كلية & \\
\hline 17 & $1 \leqslant$ & r & & مجموع \\
\hline$\wedge$ & 1 & V & 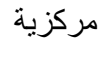 & \multirow{2}{*}{ اتاحة غير مجانية } \\
\hline$\wedge$ & 1 & V & كلية & \\
\hline 17 & r & $1 \leqslant$ & & مجموع \\
\hline$\wedge$ & r & 7 & مركزية & \multirow{2}{*}{ رعاية أطفال } \\
\hline$\wedge$ & . & $\wedge$ & كلية & \\
\hline 17 & r & $1 \varepsilon$ & & مجموع \\
\hline$\wedge$ & • & $\wedge$ & مركزية & \multirow{2}{*}{ 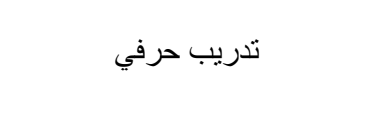 } \\
\hline$\wedge$ & . & $\wedge$ & كلية & \\
\hline 17 & • & 17 & & مجموع \\
\hline$\wedge$ & 1 & V & مركزية & \multirow{2}{*}{ تدريب مهني } \\
\hline$\Lambda$ & $\cdot$ & $\Lambda$ & كلية & \\
\hline 17 & 1 & 10 & & 11 \\
\hline$\wedge$ & $\varepsilon$ & $\varepsilon$ & مركزية & \multirow{2}{*}{ تدريب على تكنولوجيا المعلومات } \\
\hline$\wedge$ & 1 & V & كلية & \\
\hline 17 & 0 & 11 & & مجموع \\
\hline$\wedge$ & · & $\wedge$ & مركزية & \multirow{2}{*}{ لا شيء مما سبق } \\
\hline$\Lambda$ & $\cdot$ & $\Lambda$ & كلية & \\
\hline 17 & $\cdot$ & 17 & & مجموع \\
\hline
\end{tabular}

وربما كانت هذه النتيجة منوقعة، حيث إن معظم لوائح الجامعات و الكليات تتص على عدم

فرض رسوم إضافية تخصص لاستخدام المكتبة، إلا أنه ـ ربما للظروف الاقتصادية ـ اضطرت إدارة بعض الجامعات والكليات لفرض رسوم مستقلة لاستخدام المكتبة، وهو أمر سلبي وفقًا

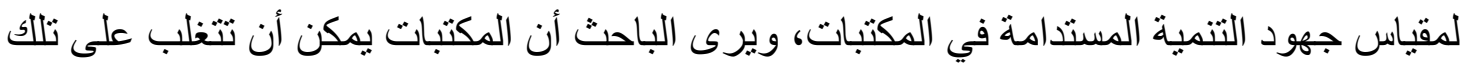

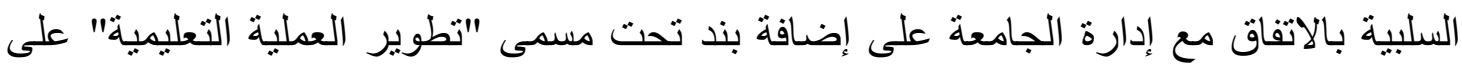

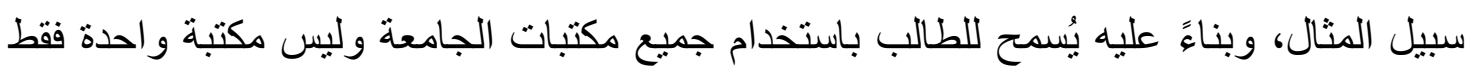
(المركزية)، ولتفادي تحصيل أي رسوم بشكلٍ منفصلٍ، حيث ستُحصَّل على أنها رسوم در اسية 
وليس رسومًا لاستخدام المكتبة، ولكن لا زال هنالك قصورٌ في تقديم خدماتٍ أخرى، مثل: دار

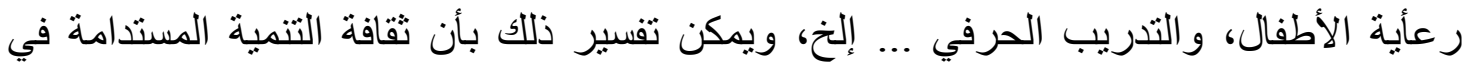
المكتبات الأكاديمية لم ترقَ بعد إلى المسنوى الذي يمكن وصفه بالفعَّال.

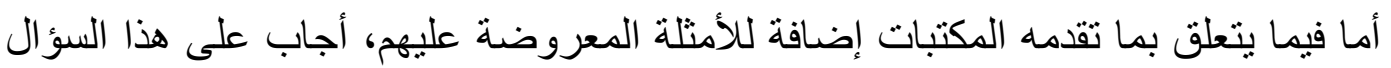

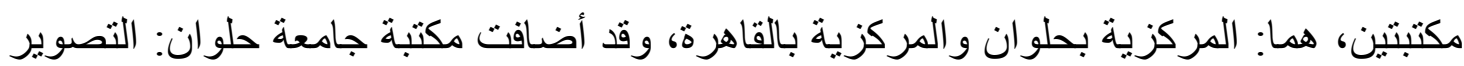

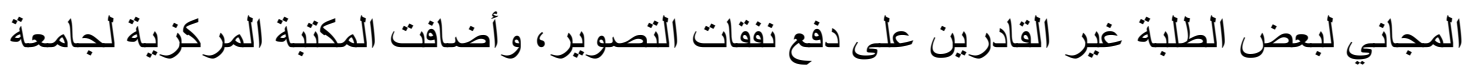

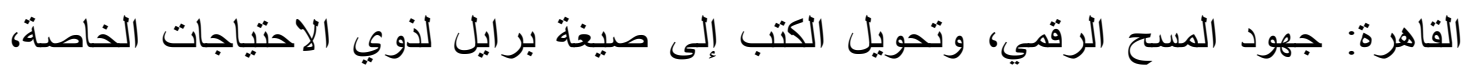

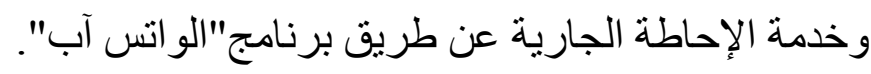

ولم تقدم أي من المكتبات المشاركة أية اقتراحات لما يمكن أن يُستحدَث، ويضاف إلى إلى قائمة

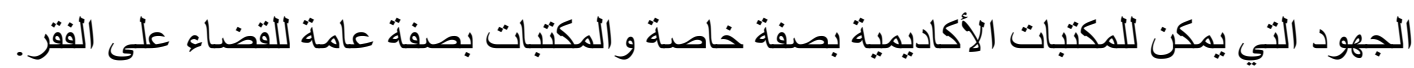

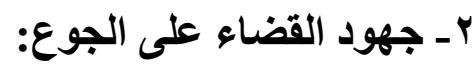

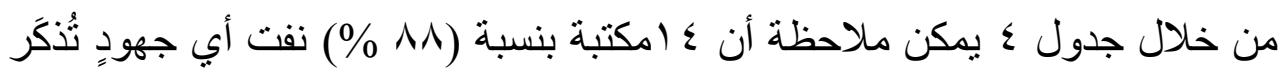

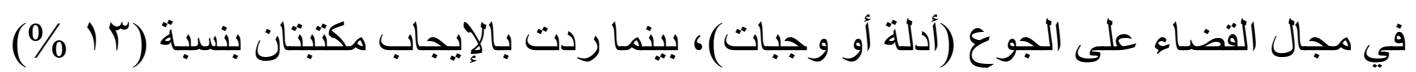

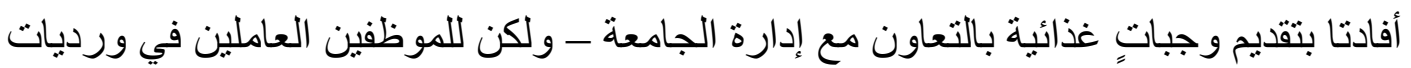
طويلة فقط - هما: المكتبة المركزية لجامعة حلوان، و المكتبة المركزية لجامعة عين شمس.

جدول ؛ توزيع أعداد الدكتبات بثأن جهود القضاء على الجوع وفقًا للنوع

\begin{tabular}{|c|c|c|c|c|}
\hline مجموع & نُعم & $\bar{\gamma}$ & نؤ & متَفِير \\
\hline$\wedge$ & $r$ & 7 & مركزية & \multirow{2}{*}{ تقديم وجبات } \\
\hline$\lambda$ & $\cdot$ & $\lambda$ & كلية & \\
\hline 17 & T & Tह & & مجموع \\
\hline$\lambda$ & $T$ & $\bar{V}$ & مركزية & \multirow{2}{*}{ أدلة أماكن تقام وجبات مجانية } \\
\hline$\wedge$ & - & $\Lambda$ & كلية & \\
\hline 17 & T & 10 & & مجموع \\
\hline$\lambda$ & o & $T$ & هركزية & \multirow{2}{*}{ لا شيء مما سبق } \\
\hline$\lambda$ & $\lambda$ & $\cdot$ & كلية & \\
\hline 17 & $\pi$ & $T$ & & هجموع \\
\hline
\end{tabular}


و على الرغم من أن الغالبية أجابت بالنفي، فإن هنالك وإن كان قليلًا من يقوم بدورٍ إيجـابي -

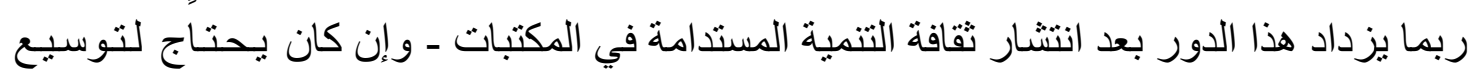
نطاق التطبيق ليشمل الطلاب، وربما يكون هذا الأمر صعب التنفيذ لكل من يدخل المكتبة، ومن ثم

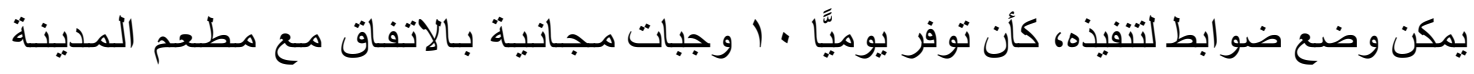

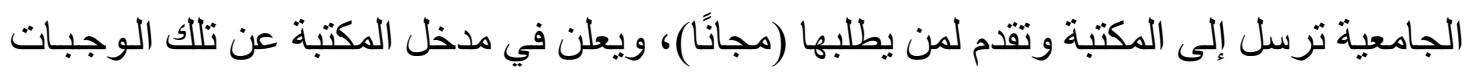

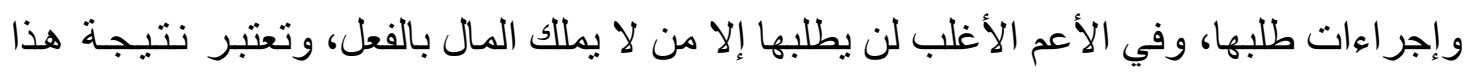

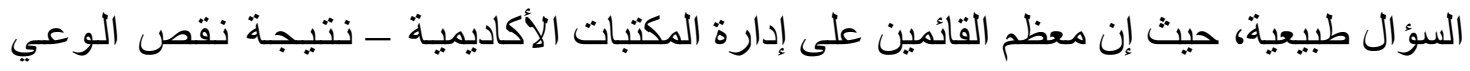

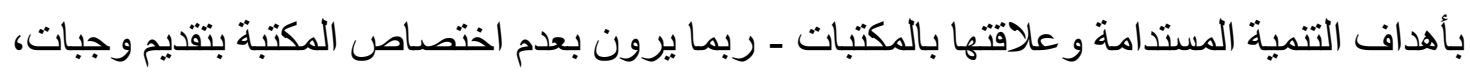

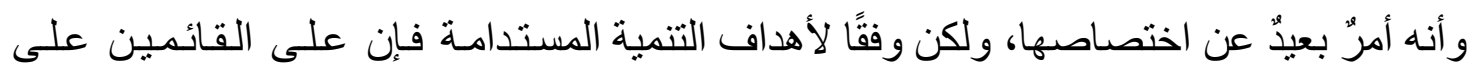
المكتبات الأكاديمية بصفة خاصة، و المكتبات بصفة عامة، تغيير نظرتهم إلى المكتبة و اعتبار ها -

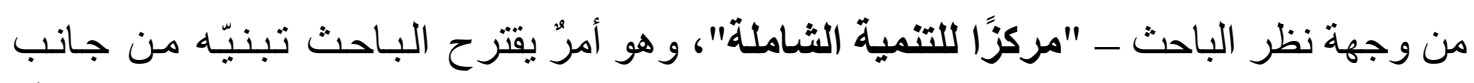
مؤسسات الدولة المتخصصة ومن جانب المتخصصين بالمجال، بحيث يُستخدَم مصطلّح - وفقًا

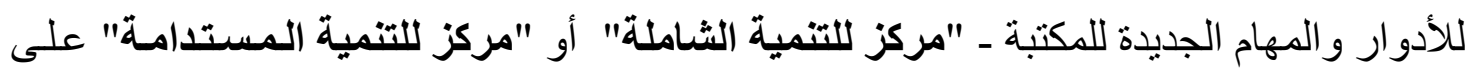
المكتبة الأكاديمية بصفة خاصة و أي مكتبةٍ بصفة عامة تساهم بشكلٍ فعَّالٍ في جميع محاور التنمية

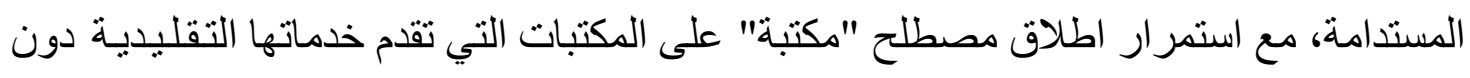

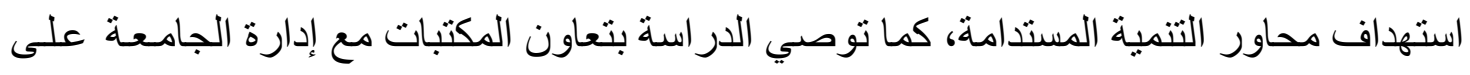
توفير وجباتٍ مجانية للطلاب.

ولم تقدم أي من المكتبات أبة إضـافاتٍ بخصوص جهود تُذكَر تقوم بـها إضـافـة للأمثلـة المعروضة عليهم، كما لم تقدم أي من المكتبات المشاركة أية اقتر احاتٍ يمكن استحداثها ــ مختلفة فئة

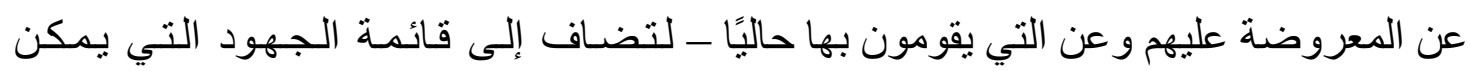
للمكتبات الأكاديمية بصفة خاصة، و المكتبات بصفة عامة؛ للقضاء على الفقر.

\section{"- جهود الحفاظ على صحة جيدة:}

لم تقدم 9 من المكتبات بنسبة ( •9 \%) - كما يلاحظ من جدول ه - ـ أي جهود ثُذكَر في

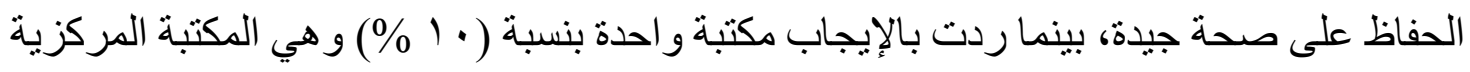
بجامعة القاهرة، حيث أفادت بتقديم ندوات توعية صحية إلى جانب تقديم خدماتٍ صحية بالتعاون

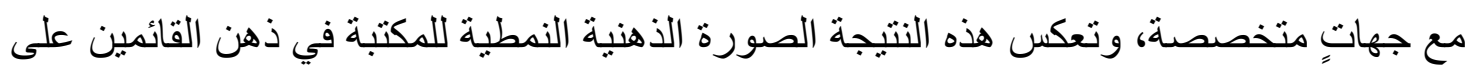
إدارتها، و التي انعكست على عدم الاهتمام بدور المكتبات في هذا الثأن، ومن ثم توصي الدهنه إجر اء اتفاقيات وبروتوكو لات تعاون مع جهات طبية لتقديم خدماتٍ صحية من داخل المكتبة، إلى إنى جانب الاهتمام بالتو عية الصحية كدورٍ جديدٍ عليها. 


\section{جدولهتوزيع أعداد المكتبات بثأن جهود الحفاظ على صحة جيدة وفقًا للنوع}

\begin{tabular}{|c|c|c|c|c|}
\hline مجموع & 'نُعم & $\bar{y}$ & نوع & متُفير \\
\hline 1 & $\varepsilon$ & $\varepsilon$ & مركزية & \multirow{2}{*}{ توعية صحية } \\
\hline$\lambda$ & $T$ & 7 & كلية & \\
\hline 17 & 7 & 1. & \multicolumn{2}{|c|}{ مجموع } \\
\hline$\lambda$ & $\xi$ & $\xi$ & مركزية & \multirow{2}{*}{ خدمات طبية } \\
\hline$\lambda$ & $\cdot$ & $\lambda$ & كلية & \\
\hline 17 & $\xi$ & $T$ & \multicolumn{2}{|c|}{ مجموع } \\
\hline$\lambda$ & $\xi$ & $\xi$ & مركزية & \multirow{2}{*}{ لا شيء مما سبق } \\
\hline$\lambda$ & 7 & $T$ & كلية & \\
\hline 17 & 1. & 7 & \multicolumn{2}{|c|}{ مجموع } \\
\hline
\end{tabular}

ولم تقدم أي من المكتبات أية إضافاتٍ بخصوص جهودٍ تُذكَر تقوم بها إضافة للأمثلة المعروضة عليهم، كما لم تقام أي من المكتبات المشاركة أية اقتر احاتٍ يمكن استحداثها ـ مختلفة عن المعروضة عليهح و عن التي يقومون بها حاليًا لتضاف إلى قائمة الجهود التي يمكن للمكتبات الأكاديمية بصفة خاصة و المكتبات بصفة عامة؛ للحفاظ على صحة جيدة.

ع - توفير وتعزيز تعليم جيد:

يعكس جدول 1 النتائج المتعلقة بمحور توفير وتعزيز تعليم جيد، ومنه يمكن ملاحظة أن 10 مكتبة بنسبة ( 9 \%) أفادت بأنها لم تقدم أي من المقترحات المعروضة عليهم (تقديم دور ات محو الأمية، وتقديم دروس تقويم لمختلف المر احل الدراسية)، و أفادت واحدة فقط بنسبة (؟\%\%) بأنها تقدم دوراتٍ لمحو الأمية وهي مكتبة الجامعة الأمريكية.ويمكن تفسير تلك النتيجة إلى عدم انتشار ثقافة التنمية المستدامة بالثكل الكافي، كما قد ير غب أحدهم في تنفيذ أفكار إبداعية تخدم الأهداف

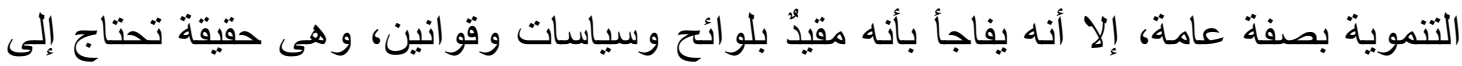
تعديل لتتلاعم مع دور المكتبة الجديد في دعم أهداف التنمية المستدامة، وهو أمرٌ يحتاج للطرح

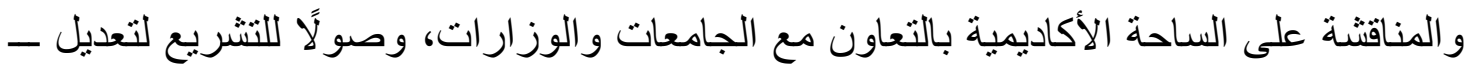

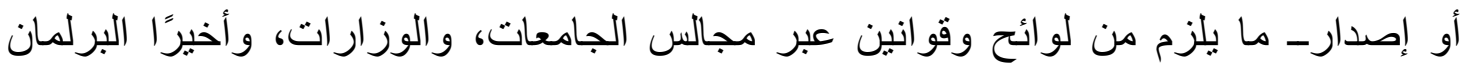
بحسب ما يتتاسب مع كل حالة. 


\section{جدول \ توزيع أعداد المكتبات بشأن جهود الحفاظ على صحة جيدة وفقًا للنوع}

\begin{tabular}{|c|c|c|c|c|}
\hline مجموع & نُعم & $\bar{y}$ & نوع & متغير \\
\hline$\Lambda$ & 1 & V & مركزية & \multirow{2}{*}{ دورات محو الامية } \\
\hline$\lambda$ & $\cdot$ & $\lambda$ & كلية & \\
\hline 17 & $T$ & 10 & \multicolumn{2}{|c|}{ مجموع } \\
\hline$\lambda$ & $\cdot$ & $\lambda$ & مركزية & \multirow{2}{*}{ دروس تقوية } \\
\hline$\lambda$ & $\cdot$ & $\lambda$ & كلية & \\
\hline 17 & $\cdot$ & 17 & \multicolumn{2}{|c|}{ مجموع } \\
\hline$\lambda$ & $\bar{V}$ & $T$ & مركزية & \multirow{2}{*}{ لا شيء مما سبق } \\
\hline$\lambda$ & $\lambda$ & $\cdot$ & كلية & \\
\hline 17 & 10 & $T$ & \multicolumn{2}{|c|}{ مجموع } \\
\hline
\end{tabular}

وفيما يتعلق بإضافات المكتبات في هذا الصدد، أضافت المكتبة المركزية لجامعة القاهرة بأنها تقدم جهودًا هي: تقديم محاضرات عامة في مختلف الجوانب السياسية والاقتصادية و الاجتماعية، وورش عمل متخصصة في مجالات (المكتبات، وتكنولوجيا المعلومات، والبحث

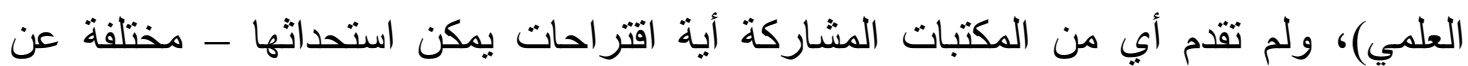
المعروضة عليهم و عن التي يقومون بها حاليًا ــ لتضاف إلى قائمة الجهود التي يمكن للمكتبات الأكاديمية بصفة خاصة و المكتبات بصفة عامة تنفيذها؛ لتوفير تعليم جيد.

\section{هـ تحقيق المساواة بين الجنسين:}

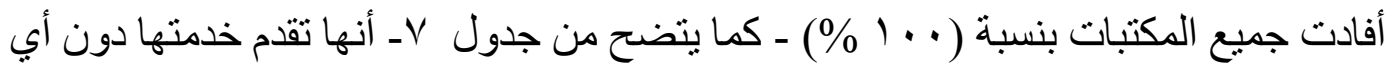

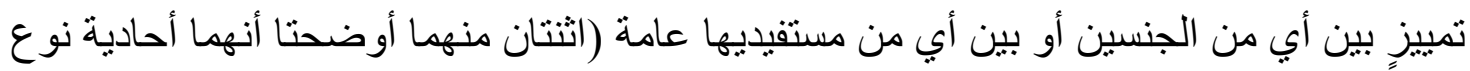
المستفيدين، هما: مكتبة تربية رياضية بنات، ومكتبة أصول الدين بنين)، و أفادت مكتبتان

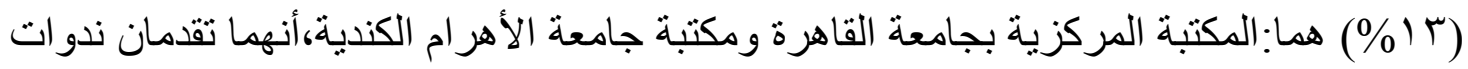

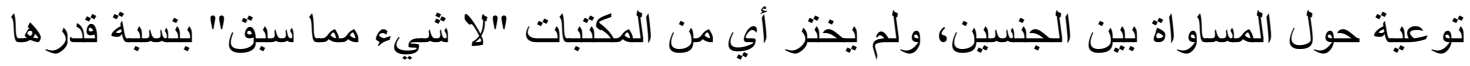

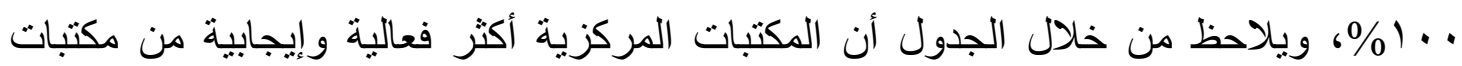
الكليات، وإن كانت جهود التوعية بالمساوة بين الجنسين لا ترقى إلى المستوى المأمول. 
جدول V توزيع جهود المكتبات في تحقيق المساواة وفقًا للنوع

\begin{tabular}{|c|c|c|c|c|}
\hline مجموع & نعم & ע & نوع & متغير \\
\hline$\wedge$ & $\wedge$ & · & مركزية & تقديم الخدمات دون تمييز بين \\
\hline$\Lambda$ & $\Lambda$ & . & كلية & \\
\hline 17 & 17 & $\cdot$ & & مجموع \\
\hline$\Lambda$ & $r$ & 7 & مركزية & \multirow{2}{*}{ ندوات حول المساو اة } \\
\hline$\Lambda$ & $\cdot$ & $\Lambda$ & كلية & \\
\hline 17 & $r$ & $1 \varepsilon$ & & مجموع \\
\hline$\Lambda$ & $\Lambda$ & $\cdot$ & مركزية & \multirow[b]{2}{*}{ لاشيء مما سبق } \\
\hline$\wedge$ & $\Lambda$ & $\cdot$ & كلية & \\
\hline 17 & 17 & . & & مجموع \\
\hline
\end{tabular}

وفيما يتعلق بالجهود الأخرى التي تقوم بها المكتبات في هذا الثأن، أضافت المكتبة المركزية بجامعة القاهرة أن المساواة تتم أيضًا على نطاق العمل داخل المكتبة بين الموظفين فيما يتعلق هُقات بالحو افز و المكافآت،لوم يضف أي منهم أية مقترحاتٍ بجهود بمكن استحداثها بهذا الثأن.

\section{צ- توفير مياه نظيفة وصرف صحي:}

أكدت ا (مكتبة بنسبة (9 7 \%) - كما يوضح جدول ^ــ أنهم يوفرون دورات مياه صحية،

ونفت وجود دورات مياه ه مكتبات بنسبة (اس\%\%)، وبالاستفسار من بعض المجيبين اتضح أن

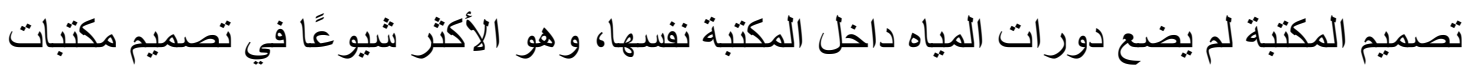
الكليات، والمكتبات التي أفادت بعدم وجود دور ات مياه هي: مكتبة كلية الطب جامعة حلوان، ومكتبة المعهد العالي للموسيقى العربية، ومكتبة كلية التجارة جامعة عين شمس، ومكتبة كلية

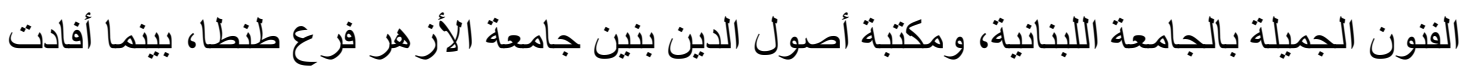

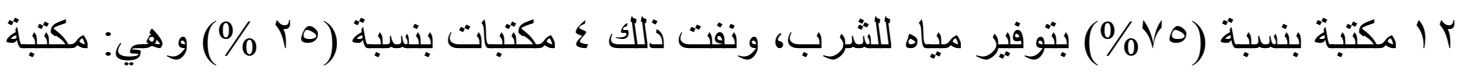
كلية الطب جامعة حلوان، ومكتبة المعهد العالي للموسيقى العربية، ومكتبة كلية الفنون الجميلة بالجامعة اللبنانية، ومكتبة أصول الدين بنين جامعة الأزهر فرع طنطا، بينما أكدت ع مكتبات بنسبة (0 \% \%) بتقديم ندوات حول أهمية المياه و عدم الإسراف فيها وهى:المكتبة المركزية لجامعة القاهرة، ومكتبة الجامعة الأمريكية، ومكتبة جامعة الثارقة، ومكتبة جامعة الأهرام

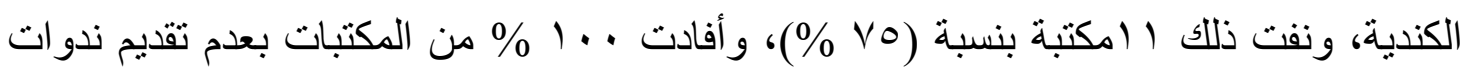
حول أهمية الصرف الصحي، ولم يختر لا شيء مما سبق سوى ع مكتبات هي: مكتبة كلية أصول الدين، ومكتبة الفنون الجميلة، ومكتبة العهد العالي للموسيقى العربية، ومكتبة كلية الطب جاهعة الهية 
حلوان. ويتضح من الجدول أيضًا مدى تفوق المكتبات المركزية على مكتبات الكليات، ويمكن

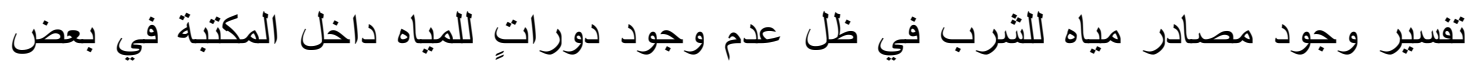

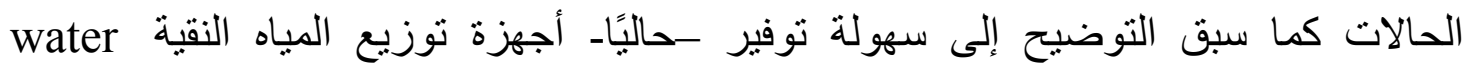
despencer الدر اسة بأن بر اعى عند تصميم مباني المكتبات سواء مكتبات الكليات أو مكتبات الجامعات (المركزية) أن يكون هنالك دور ات مياه ومصادر مياه صالحة للشرب داخل نفس مكان قاعات الاطلاع،خاصة وأن المستفيد يمكث عادة وقتًا ليس بالقليل داخل المكتبة، إلى جانب الاهتمام

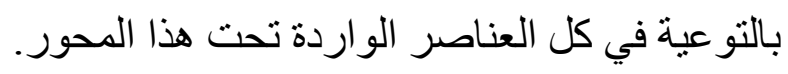

جدولم توزيع جهود المكتبات في توفير مياه نظيفة وصرف صحي وفقًا للنوع

\begin{tabular}{|c|c|c|c|c|}
\hline مجموع & نمع & $\bar{\gamma}$ & نوع & متغير \\
\hline$\wedge$ & $\wedge$ & · & مركزية & توفيردور ات مياه صحية \\
\hline$\lambda$ & $T$ & 0 & كلية & \\
\hline 17 & $\pi$ & 0 & & مجموع \\
\hline$\lambda$ & $\lambda$ & $\cdot$ & مركزية & \multirow{2}{*}{ توفير مياه للشرب } \\
\hline$\lambda$ & $\xi$ & $\xi$ & كلية & \\
\hline 17 & $T \pi$ & $\xi$ & & مجموع \\
\hline$\lambda$ & $\xi$ & $\xi$ & مركزية & \multirow{2}{*}{ تو عية أهمية المياه و عدم الإسر اف فيها } \\
\hline$\wedge$ & . & $\wedge$ & كلية & \\
\hline 17 & $\varepsilon$ & $T$ & & مجموع \\
\hline$\lambda$ & $\lambda$ & $\cdot$ & مركزية & \multirow{2}{*}{ توعية أهمية وجود صرف صحي } \\
\hline$\lambda$ & $\lambda$ & $\cdot$ & كلية & \\
\hline 17 & 17 & $\cdot$ & & مجموع \\
\hline$\lambda$ & $\cdot$ & $\lambda$ & مركزية & \multirow{2}{*}{ لاشيء مما سبق } \\
\hline$\lambda$ & $\xi$ & $\xi$ & كلية & \\
\hline 19 & $\xi$ & $\pi$ & & مجموع \\
\hline
\end{tabular}

وبخصوص الجهود التي تقوم بها المكتبات ولم تُذكَر في الأمثلة المعروضة عليهم، أضافت

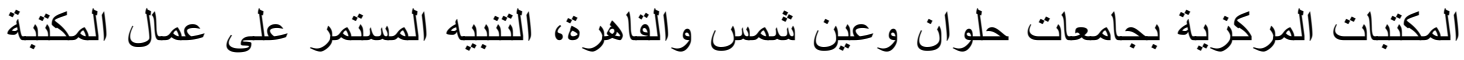

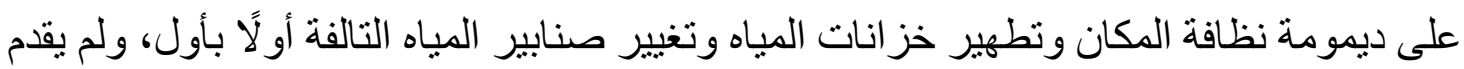

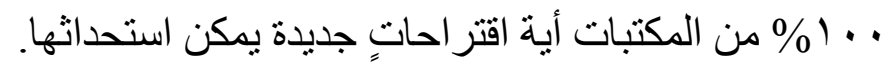




\section{V- ترشيد استخدام الطاقة وتوفير الطاقة النظيفة:}

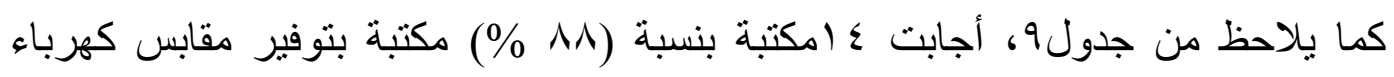

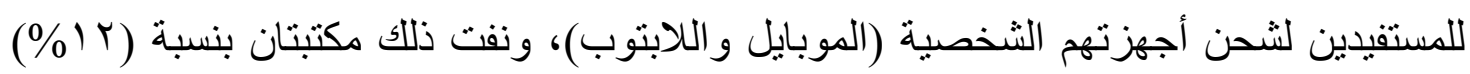

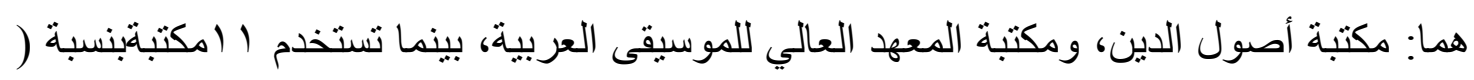
79 \% \% منها لمبات نيون، ونفت ذلك م مكتبات هي: مكتبة الأهر ام الكندية، ومكتبة جامعة نايف، ومكتبة كلية الآداب جامعة الكويت، ومكتبة جامعة الثارقة،ومكتبة كلية الفنون الجميلة

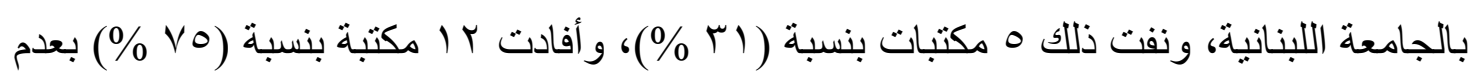
استخدام لمبات ليد، في حين أكدت ع مكتبات بنسبة (0 Y \%) باستخدامهاهو هي: مكتبة جامعة الأهرام الكندية، ومكتبة جامعة نايف، ومكتبة جامعة الثارقة، ومكتبة كلية الفنون الجميلة بالجامعة اللبنانية، ونفت سا مكتبة بنسبة (1) 1 \% القيام بالتوعية حول أهمية الطاقة وعدم

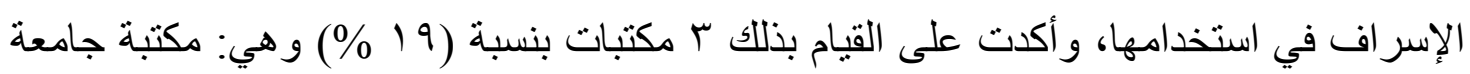
الأهر ام الكندية، ومكتبة جامعة نايف، ومكتبة جامعة الثارقة، ومكتبة الجامعة الأمريكية، ولم يختر أي منهم "لا شيء مما سبق"، ويمكن تفسير استخدام لمبات النيون بكثرة عن لمبات الليد بسبب أن الأولى أرخص، ومستخدمة من فترة، ولحداثة الثانية لا تزال مرتفعة الثمن، ووفقًا

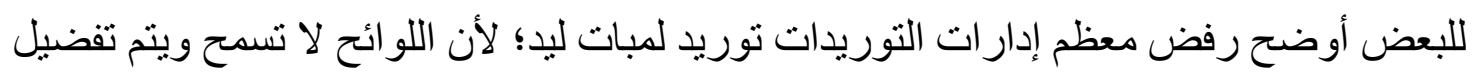
السعر الأرخص، وهو أمرٍ يحتاج للنظر في تعديله بمشروعٍ قومي على مستوى الجامعات

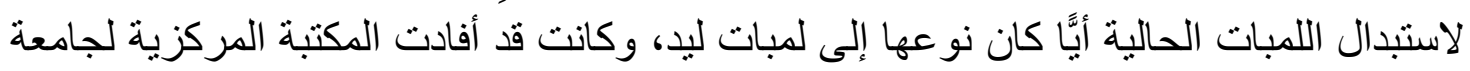
حلوان بأن المبنى نو افذه كبيرة ومصمم بشكلٍ بسمح بإنارة الإضاءة الطبيعية قاعات الاطلاع دون الحاجة إلى إضاءة كهربائية حتى وقت متأخر من اليوم، وهو أمرٌ شاهده الباحث بنفسه، على بلى بانى عكس ما هو مطبق في مكتبة جامعة القاهرة؛ فمعظم قاعات الاطلاع في مركز المبنى و القليل منها على أطر افه، ومن ثم تحتاج القاعات الموجودة داخل المبنى إلى توفير إضلاءة كهربائية

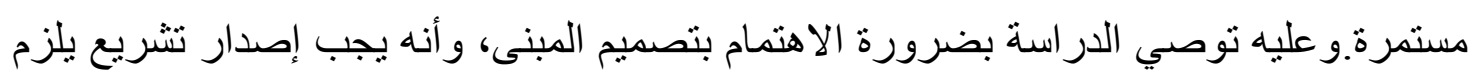
بأن كل مبنى حكومي - بما فيها المكتبات ـ سيتم إنشاؤه يجب أن يُصمَّم ويُنفَّذ كـ "مبنى مستدام Sustainable Building" 
جدوله توزيع جهود المكتبات في ترشيد استخدام الطاقة وتوفير الطاقة النظيفة وفقًا للنوع

\begin{tabular}{|c|c|c|c|c|}
\hline 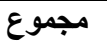 & 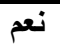 & $y$ & نوع & 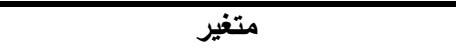 \\
\hline$\Lambda$ & $\lambda$ & $\cdot$ & مركزية & توفير مقابس كهربائية لثُن الاجهزة \\
\hline$\Lambda$ & 7 & $r$ & كلية & \\
\hline 17 & $1 \varepsilon$ & $\bar{r}$ & & مجموع \\
\hline$\Lambda$ & 0 & $r$ & مركزية & \multirow{2}{*}{ استخدام لمبات نيون } \\
\hline$\lambda$ & 7 & $\bar{Y}$ & كلية & \\
\hline 17 & $\pi$ & 0 & & مجموع \\
\hline$\lambda$ & $\xi$ & $\xi$ & مركزية & \multirow{2}{*}{ استخدام لمبات ليد } \\
\hline$\lambda$ & $\bar{T}$ & $\lambda$ & كلية & \\
\hline 17 & $\xi$ & $T$ & & مجموع \\
\hline$\lambda$ & $T$ & 0 & مركزية & \multirow{2}{*}{ التو عية بأهمية الطاقة و عدم الإسر اف فيها } \\
\hline$\lambda$ & $\cdot$ & $\lambda$ & كلية & \\
\hline 17 & $\Gamma$ & $T$ & & مجموع \\
\hline$\lambda$ & $\cdot$ & $\lambda$ & مركزية & \multirow{2}{*}{ لا شيء مما سبق } \\
\hline$\lambda$ & $\bar{T}$ & $\lambda$ & كلية & \\
\hline 17 & $\cdot$ & 17 & & مجموع \\
\hline
\end{tabular}

وبخصوص الجهود التي تقوم بها المكتبات ولم تذكر في الأمثلة المعروضة عليهمكلم تذكر أي منهمأية إضافات يقومون بها حاليًا، وكذلك لم يضف أي منهم أية مقترحاتٍ بجهودٍ يمكن

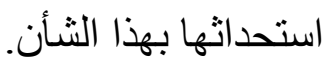

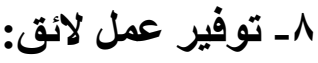

لم تقدم أي مكتبة من المكتبات محل الدراسةـ كما يوضح جدول • 1 ـ ـ أي جهٍ فيما يتعلق

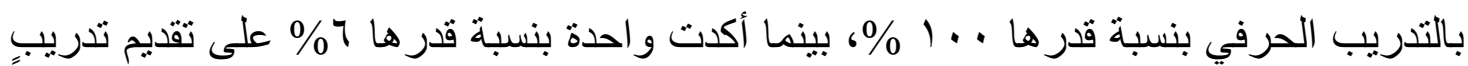

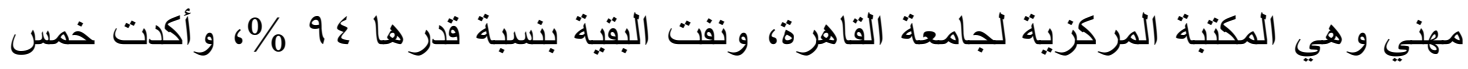
مكتبات أنها تقدم تدريبًا مجانيًاعلى تكنولوجيا المعلومات، وهيى: مكتبة الجامعة الأمريكية، و المكتبة المركزية لجامعة القاهرة، ومكتبة كلية التربية الرياضية، ومكتبة جامعة نايف، ومكتبة جامعة الأهر ام الكندية، بينما أقرت با مكتبة بنسبة (1 1 \%) بعدم الإعلان للمستفيدين عن الوظائف الثاغرة، في حين أكدت ذلك ب مكتبات بنسبة (19 1\%) هي: مكتبة كلية التربية الرياضية بنات، و المكتبة المركزية لجامعة القاهرة، ومكتبة جامعة بنها، وربما يمكن تفسير عدم وجود حرفي إلى أن ذللك يستلزم وجود ورش وأدوات للتدريب، وهو أمرٌ ستقف أمامه اللوائح 
الحالية، والتي ستحتاج إلى تعديل إلى جانب تعديل فكر القائمين على إدارة المكتبات الجامعية بصفة خاصة، و المكتبات على اختلاف أنواعها بصفة عامة، ويعتبر هذا الدور مهمَّا؛ فالجامعة

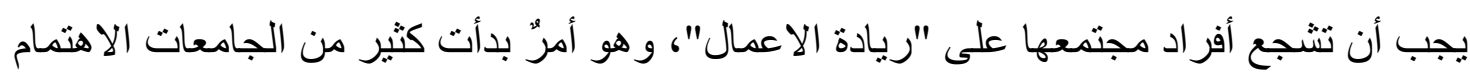
به مؤخرًا، فلتكن المكتبات في دور ها التنموي الجديد "كمركز للتنمية الثاملة" أو "كمركز للتنمية

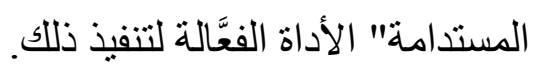

\section{جدول • ا توزيع جهود المكتبات في تحقيق المساواة وفقًا للنوع}

\begin{tabular}{|c|c|c|c|c|}
\hline مجموع & ن مم & $\gamma$ & نوع & متغير \\
\hline$\wedge$ & 1 & V & مركزية & توفيرتدريب مهني \\
\hline$\wedge$ & . & $\Lambda$ & كلية & \\
\hline 17 & 1 & 10 & & مجموع \\
\hline$\lambda$ & $\cdot$ & $\lambda$ & مركزية & \multirow{2}{*}{ توفير تدريب حرفي } \\
\hline$\lambda$ & $\bar{r}$ & $\lambda$ & كلية & \\
\hline 17 & $\cdot$ & 17 & & مجموع \\
\hline$\lambda$ & T & 7 & مركزية & \multirow{2}{*}{ توفير إعلانات عن الوظائف } \\
\hline$\lambda$ & $T$ & V & كلية & \\
\hline 17 & $T$ & $\pi$ & & مجموع \\
\hline$\lambda$ & $\xi$ & $\xi$ & مركزية & \multirow{2}{*}{ توفير تدريب على تكنولوجيا المعلومات } \\
\hline$\lambda$ & $T$ & V & كلية & \\
\hline 17 & 0 & $\pi$ & & مجموع \\
\hline$\lambda$ & T & 7 & مركزية & \multirow{2}{*}{ لا شيء مما سبق } \\
\hline$\lambda$ & 7 & T & كلية & \\
\hline 17 & $\Lambda$ & $\Lambda$ & & مجموع \\
\hline
\end{tabular}

وفيما يتعلق بإضافات المكتبات في هذا الثأن، أفادت مكتبة التربية الرياضية بنات بالإسكندرية بأنها تقدم دوراتٍ لكيفية الوصول لمصادر المعلومات، ولم يضف أي منهم أية مقترحاتٍ بجهودٍ بمكن استحداثها بخصوص هذا الصدد.

\section{9- تشجيع الابتكار والتصنيع:}

يلاحظ من جدول /أن ال 1 مكتبة بنسبة (9 \% \%) أفادت بعدم القيام بأي جهودٍ لدعم

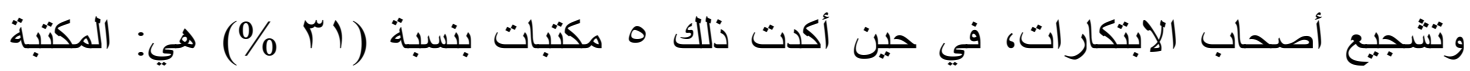
المركزية جامعة حلوان، ومكتبة كلية الآداب جامعة الكويت، ومكتبة جامعة الثارقة، و المكتبة 
المركزية لجامعة القاهرة، ومكتبة الجامعة الأمريكية، أما فيما يتعلق بإعداد ندواتٍ حول الابتكار و الإبداع فأفادت بالإيجاب م مكتبات بنسبة (اس \%) هي: مكتبة كلية الآداب جامعة الكويت، ومكتبة جامعة الثارقة، والمكتبة المركزية لجامعة القاهرة، ومكتبة الجامعة الأمريكية، ومكتبة

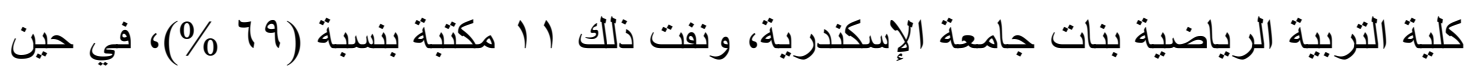
أفادت و احدة فقط بنسبة (7 \%) بإقامة ندو اتٍ حول أهمية التصنيع و التعليم الصناعي وهي: مكتبة

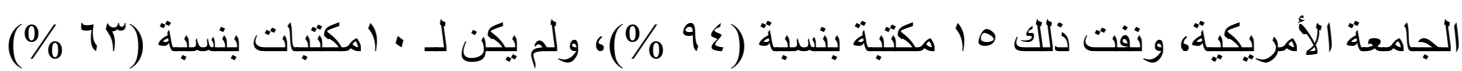
أي جهذِ يُذكَر في هذا الثأن، وتوضح النتائج استمرار تفوق المكتبات المركزية على مكتبات الكليات، وإن كان الاهتمام في كليهما بهذا المحور من التتمية المستدامة يحتاج إلى مزيدٍ من هن التفعيل، ولا مبرر لهم هنا لهذا القصور، فلا توجد لوائح أو قوانين تمنعهم من التوعية بأهمية التصنيع أو دعم المبدعين والمبتكرين، ومن ثم توصي الدراسة بمزيدٍ من الاهتمام من جانب المكتبات الأكاديمية.

جدول ال اتوزيع جهود المكتبات في تثجيع الابتكار والتصنيع وفقًا للنوع

\begin{tabular}{|c|c|c|c|c|}
\hline مجموع & نعم & V & نوع & متغير \\
\hline$\wedge$ & $\varepsilon$ & $\varepsilon$ & مركزية & دعموتشجيع أصحاب الابتكارات \\
\hline$\Lambda$ & 1 & $\mathrm{~V}$ & كلية & \\
\hline 17 & 0 & $\pi$ & & مجموع \\
\hline$\Lambda$ & $r$ & 0 & مركزية & \multirow{2}{*}{ ندوات حول الابداع والابتكار } \\
\hline$\wedge$ & r & 7 & كلية & \\
\hline 17 & 0 & $\pi$ & & مجموع \\
\hline$\wedge$ & 1 & $\bar{v}$ & مركزية & \multirow{2}{*}{ توعية بأهمية التصنيع و التعليم الصناعي } \\
\hline$\Lambda$ & $\cdot$ & $\lambda$ & كلية & \\
\hline 17 & $T$ & 10 & & مجموع \\
\hline$\wedge$ & $\varepsilon$ & $\varepsilon$ & مركزية & \multirow{2}{*}{ لا شيء مما سبق } \\
\hline$\lambda$ & 7 & T & كلية & \\
\hline 17 & T. & 7 & \multicolumn{2}{|c|}{ مجموع } \\
\hline
\end{tabular}

و أضافت مكتبة كلية التربية الرياضية بنات جامعة الإسكندرية أنها تقدم دوراتٍ تدريبية

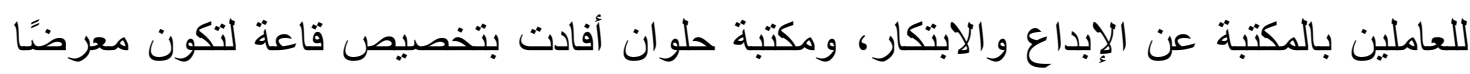

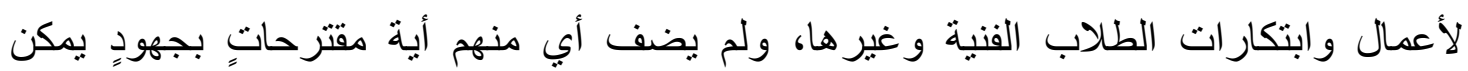
استحداثها بهذا الشأن. ان. 


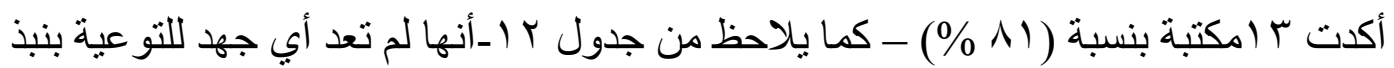
السياسات التمبيزية و العنصرية، بينما أكدت ذلكس مكتبات (9 1 \% \%) هي: مكتبة جامعة الأهر ام الكندية، والمكتبة المركزية لجامعة القاهرة، ومكتبة الجامعة الأمريكية، أما بخصوص مله إقامة

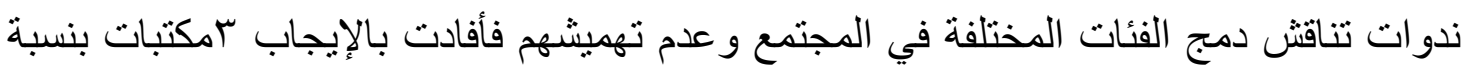
(9 19) هي: مكتبة جامعة الأهر ام الكندية، و المكتبة المركزية لجامعة القاهرة، ومكتبة الجامعة

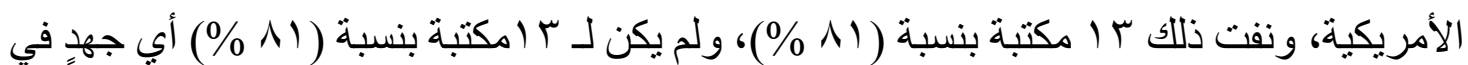
هذا الثأن، وهي جميع المكتبات ما عدا الثلاث المذكورين سابقًا، وتوضح تللك النتيجة أن الاهتمام بذلك المحور في المكتبات الأكاديمية ضعيفت في المكتبات المركزية، ومنعدم بالنسبة لمكتبات

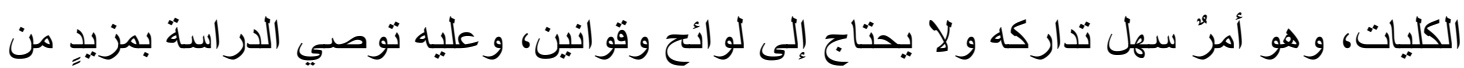
الاهتمام وتغيير طريقة تفكير القائمين على إدارة المكتبات في هذا الثأن.

جدول ب ا توزيع جهود المكتبات في تثجيع الابتكار والتصنيع وفقًا للنوع

\begin{tabular}{|c|c|c|c|c|}
\hline مجموع & نسمم & $\bar{Y}$ & (نو & منغير \\
\hline$\wedge$ & r & 0 & مركزية & توعية بنبذ السياسات التمبيزية \\
\hline$\Lambda$ & $\cdot$ & $\Lambda$ & كلية & \\
\hline 17 & r & ir & & مجموع \\
\hline$\wedge$ & r & 0 & مركزية & \multirow{2}{*}{ تو عية بدمج جميع فئات المجتمع } \\
\hline$\wedge$ & - & $\wedge$ & كلية & \\
\hline 17 & r & ir & & مجموع \\
\hline$\Lambda$ & 0 & $r$ & مركزية & \multirow{2}{*}{ ل ل شيء مما سبق } \\
\hline$\Lambda$ & $\wedge$ & $\cdot$ & كلية & \\
\hline مجموع & 17 & ir & $r$ & مجموع \\
\hline
\end{tabular}

ولم تذكر أي من المكتبات أية إضافات يقومون بها حاليًا، وكذلك لم يضف أي منهم أية مقترحاتٍ بجهودٍ يمكن استحداثها بهذا الثأن. 


\section{1 اـ تعزيز وتوفير مدن شاملة وآمنة:}

من خلال جدول ب ا يمكن ملاحظة أن ا (مكتبة بنسبة (97 \% \%) لديها منحدر صعود و هبوط لذوي الاحتياجات الخاصة، ونفت ذلك م مكتبات بنسبة ( اس \%) وهي: المكتبة المركزية جامعة عين شمس، ومكتبة المعهد العالي للموسيقى العربية، ومكتبة أصول الدين بنين، ومكتبة كلية

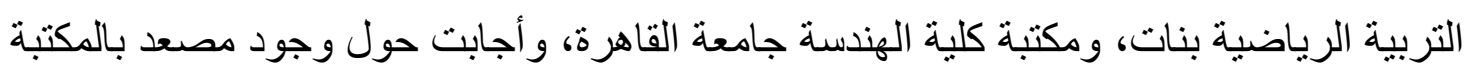
11 مكتبة بنسبة (9 \% \%)، ونفت ذلك 0 بنسبة (اس \%) هي: المكتبة المركزية جامعة عين شمس، ومكتبة المعهد العالي للموسيقى العربية، ومكتبة كلية التربية الرياضية بنات، ومكتبة كلية الهندسة جامعة القاهرة، ومكتبة كلية التجارة جامعة عين شمس، وبالإيجاب أفادت ـ 1 مكتبات بنسية (T7 \%) بوجود أفراد أمن داخل المكتبة، ونفت ذلك 7 مكتبات هي: مكتبة كلية الطب وكابل جامعة حلوان، ومكتبة المعهد العالي للموسيقى العربية، ومكتبة جامعة نايف، ومكتبة كلية الآداب جامعة الكويت، ومكتبة كلية التربية الرياضية بنات، ومكتبة كلية الهندسة جامعة القاهرة، أما

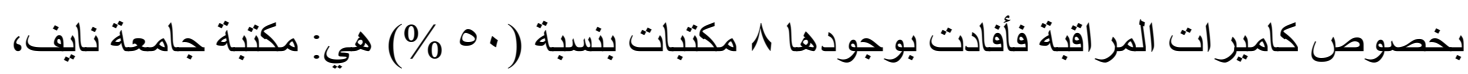
ومكتبة كلية الآداب جامعة الكويت، ومكتبة جامعة الأهر ام الكندية، و المكتبة المركزية لجامعة الهيتة القاهرة، ومكتبة الجامعة الأمريكية، ومكتبة كلية الفنون الجميلة بالجامعة اللبنانية، ومكتبة كلية

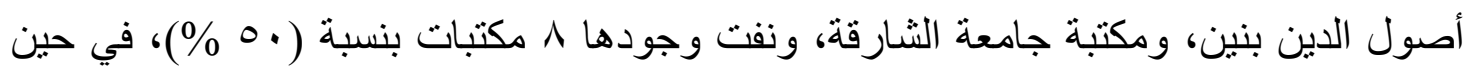
امتنعت عن الرد همكتبات بنسبة (اس \%) حول توفير مصادر معلومات ملائمة لذوي الاحتياجات الخاصة (بر ايل ومواد سمعية)، وهي: مكتبة كلية الهندسة جامعة القاهرة، وكلية

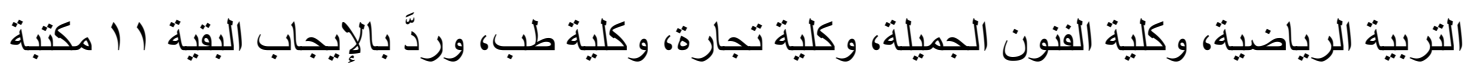

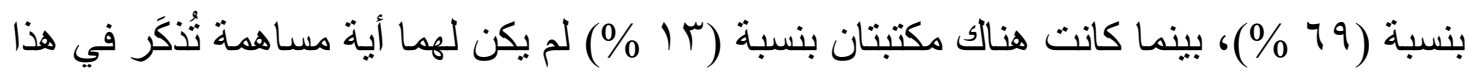
المحور وهما: مكتبة كلية الهندسة، ومكتبة كلية التربية الرياضية، وتوضح تلك النتائج الاهتمام الملحوظ من المكتبات بنوعيها بخصوص التأمين وتوفير سبل الر احة لذوي الاحتياجات الخاصة، ومن ثم توصي الدراسة بالاهنمام بثركيب كاميرات المر اقبة، إضافة إلى تركيب المصاعد في

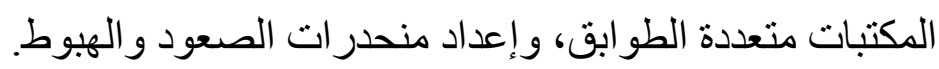


جدول ا ا توزيع جهود المكتبات في تعزيز المدن الثاملة والآمنة وفقًا للنوع

\begin{tabular}{|c|c|c|c|c|}
\hline 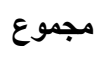 & 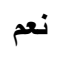 & $\gamma$ & 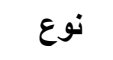 & 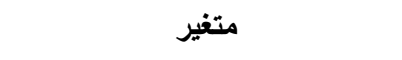 \\
\hline$\wedge$ & v & 1 & مركزية & منحدر ات لذوي الاحتياجات الخاصة \\
\hline$\wedge$ & $\varepsilon$ & $\varepsilon$ & كلية & \\
\hline 17 & 11 & 0 & & مجموع \\
\hline$\wedge$ & V & 1 & 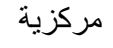 & \multirow{2}{*}{ مصعد } \\
\hline$\wedge$ & $\varepsilon$ & $\varepsilon$ & كلية & \\
\hline 17 & 11 & 0 & & مجموع \\
\hline$\Lambda$ & 0 & $r$ & مركزية & \multirow{2}{*}{ كامير ات مر اقبة } \\
\hline$\Lambda$ & $r$ & 0 & كلية & \\
\hline 17 & $\wedge$ & $\wedge$ & & مجموع \\
\hline$\Lambda$ & V & $T$ & مركزية & \multirow{2}{*}{ أفر اد امن } \\
\hline$\wedge$ & $r$ & 0 & كلية & \\
\hline 17 & 1. & 7 & & مجموع \\
\hline$\Lambda$ & $\varepsilon$ & $\varepsilon$ & مركزية & \multirow{2}{*}{ 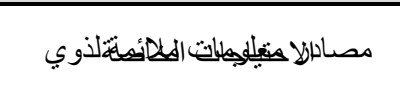 } \\
\hline$\Lambda$ & $T$ & $\bar{V}$ & كلية & \\
\hline 17 & 0 & 11 & & مجموع \\
\hline$\wedge$ & . & $\wedge$ & مركزية & \multirow{2}{*}{ لا شيء مما سبق } \\
\hline$\wedge$ & r & 7 & كلية & \\
\hline 17 & $r$ & $1 \varepsilon$ & & مجموع \\
\hline
\end{tabular}

ولم تذكر أي من المكتبات أية إضافات يقومون بهاحاليًا، وكذلك لم يضف أي منهم أية مقترحاتٍ بجهودٍ يمكن استحداثها بهذا الثأن. r ا ـ تحقيق أنماط استهلاك وأنماط إنتاج مستدامة: و فقًا للجدول التالي أفادت ثنلاثة من المكتبات بنسبة (9 19\%) بأنهم يعتمدون شر اء ورق معاد

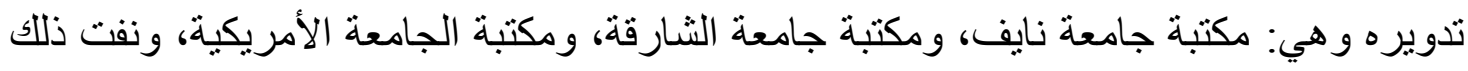
با مكتبة بنسبة (1 1 \%)، وحول إقامة ندوات أو حملات توعية بكيفية تقليل النفايات الغذائية 
أقرت بذلك مكتبتان هما: المكتبة المركزية لجامعة القاهرة، ومكتبة الجامعة الأمريكية، في حين نفت Y ا مكتبة بنسبة (0 V \%) تقديم ندواتٍ أو توعية لنشر ثقافة إعادة التدوير ، و أفادت بالإيجاب ع مكتبات (0 Y \%) هي: المكتبة المركزية لجامعة القاهرة، ومكتبة الجامعة الأمريكية، ومكتبة

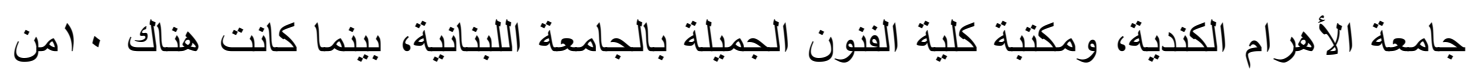

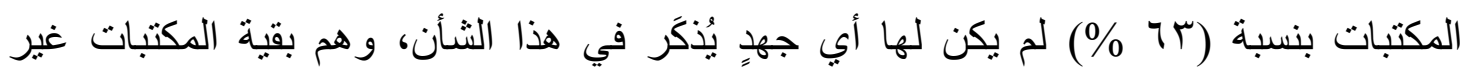
المذكورين بالفقرة الحالية، ويحتاج الأمر هنا إلى إعادة صياغة لفكر القائمين على إدارة المكتبات كما سبقت الإشارة لذللك، ومن ثم توصي الدر اسة المكتبات ـ محل الدر اسةــ ـ بيذل مزيدٍٍ من الجهـ في هذا الشأن.

جدول ؛ ا توزيع جهود المكتبات في تثجيع الابتكار والتصنيع وفقًا للنوع

\begin{tabular}{|c|c|c|c|c|}
\hline مجموع & نعم & ע & نوع & 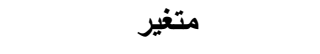 \\
\hline$\Lambda$ & $r$ & 7 & مركزية & توعية بتقليل النفايات الغذائية \\
\hline$\Lambda$ & $\cdot$ & $\wedge$ & كلية & \\
\hline 17 & $r$ & $1 \varepsilon$ & & مجموع \\
\hline$\Lambda$ & $r$ & 0 & مركزية & \multirow{2}{*}{ استخدام ورق معاد تدويره } \\
\hline$\Lambda$ & $\cdot$ & $\Lambda$ & كلية & \\
\hline 17 & $r$ & 14 & & مجموع \\
\hline$\wedge$ & $r$ & 0 & مركزية & \multirow{2}{*}{ نشر ثقافة تدوير المخلفات } \\
\hline$\wedge$ & 1 & $\checkmark$ & كلية & \\
\hline 17 & $\varepsilon$ & $\overline{I T}$ & & مجموع \\
\hline$\wedge$ & $r$ & 0 & مركزية & \multirow{2}{*}{ لا شيء مما سبق } \\
\hline$\Lambda$ & $\bar{V}$ & $T$ & كلية & \\
\hline 17 & 1. & 7 & & مجموع \\
\hline
\end{tabular}

وبخصوص الجهود التي تقوم بها المكتبات ولم تُذكَر في الأمثلة المعروضة عليهم، لم تذكر أي منهم أية إضافات يقو مون بهاحاليًا، ولم يضف أي منهم أية مقترحاتٍ بجهودٍ يمكن استحداثها بهذا الثأن. 


\section{ب ا ـ مكافحة التغير المناخي وآثاره:}

يعكس جدول 10 النتائج المتحصلة حول جهود مكافحة التغير المناخي، ومنه يمكن ملاحظة

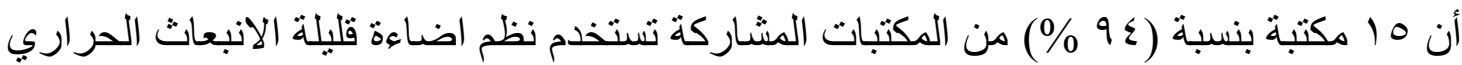
(تتر اوح ما بين ليد ونيون، وهى إن كانت تصدر انبعاثات حر ارية فهى أقل بالطبع من الانبعاثات الحرارية الناتجة عن نظم الإضاءة التي تستخدم التنجستين)، وواحدة فقط نفت ذلك هي مكتبة إنبات

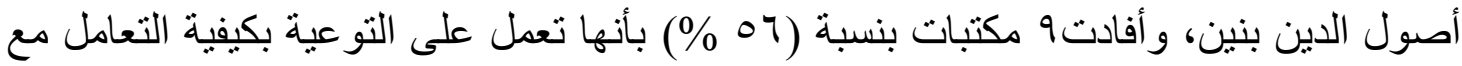

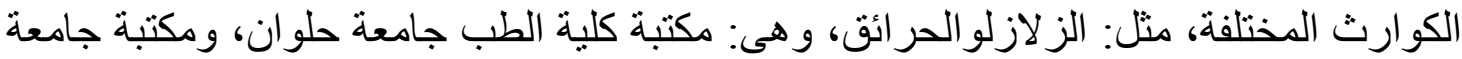

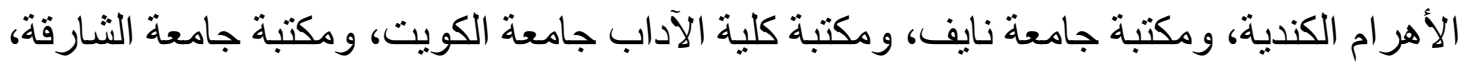

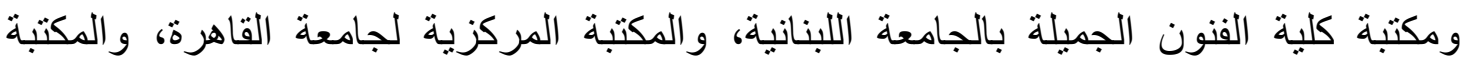

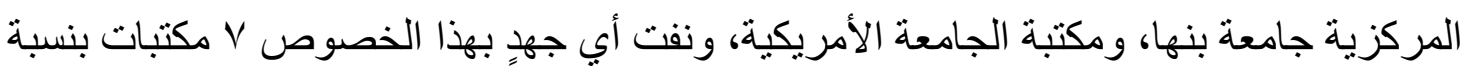

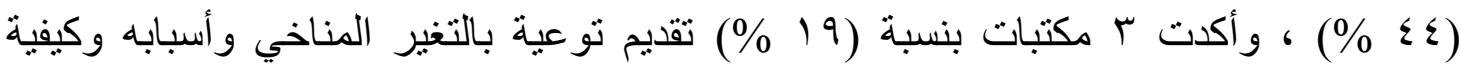

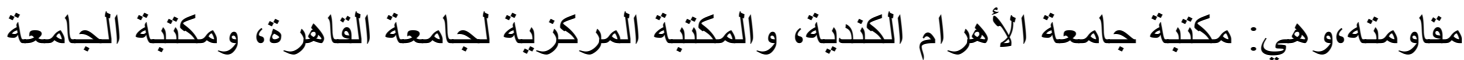

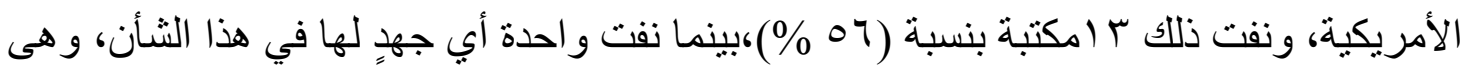

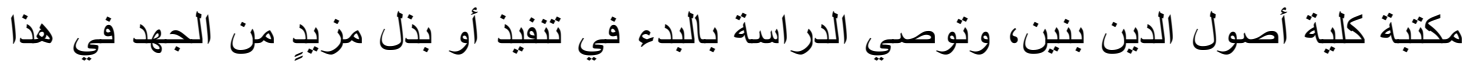

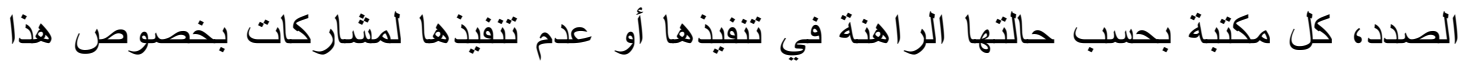
المحور من التنمية المستدامة. لحسن.

جدوله 1 توزيع جهود المكتبات في مكافحة التغير المناخي وفقًا للنوع

\begin{tabular}{|c|c|c|c|c|}
\hline مجموع & نعم & $\gamma$ & نوع & متغير \\
\hline$\Lambda$ & $\Lambda$ & $\cdot$ & مركزية & \multirow{2}{*}{ نظم اضاءة منخفضة الانبعاثات الحر ارية } \\
\hline$\Lambda$ & V & 1 & كلية & \\
\hline 17 & 10 & 1 & & مجموع \\
\hline$\Lambda$ & 7 & $T$ & مركزية & \multirow{2}{*}{ التو عية بكفية التعامل مع الكوارث } \\
\hline$\Lambda$ & $r$ & 0 & كلية & \\
\hline 17 & 9 & V & & مجموع \\
\hline$\Lambda$ & $r$ & 0 & 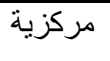 & \multirow{2}{*}{ التو عية بأسباب التغير المناخي ومكافحته } \\
\hline$\Lambda$ & . & $\Lambda$ & كلية & \\
\hline 17 & $r$ & $1 T$ & & مجموع \\
\hline$\Lambda$ & . & $\Lambda$ & مركزية & \multirow{2}{*}{ ل ل ا شيء مما سبق } \\
\hline$\Lambda$ & $T$ & $\bar{V}$ & كلية & \\
\hline 17 & $T$ & 10 & & مجموع \\
\hline
\end{tabular}


و أضافت المكتبة المركزية لجامعة القاهرة أن العاملين بحصلون على ورش عملٍ بشكلٍ دوري في الأمن الصناعي، ولم يضف أي منهم أية مقترحاتٍ بجهودٍ يمكن استحداثها بهذا الثأن.

\section{ـ ا ـ الحفاظ على النظام البيئي البحري:}

من خلال جدول 7 (، يمكن ملاحظة أن مكتبتين بنسبة (س 1 \%) أفادتا بقيامهما بالتوعية بأهمية البحار و الموارد البحرية وأهمية الحفاظ عليها، هما: مكتبة الجامعة الأمريكية، ومكتبة

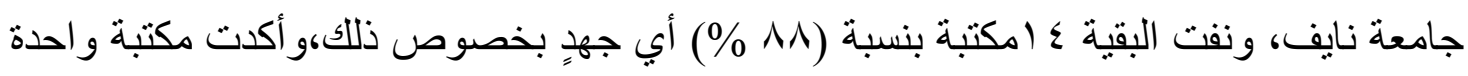
فقط بنسبة (7 \% \%) على التوعية بمكافحة الصبد البحري الجائر، وهي مكتبة جامعة نايف، ولم يكن لـ ه امكتبة بنسبة (ع 9 \%) منها أي جهدٍ يُذكرَ في هذا المحور من محاور التنمية المستدامة،

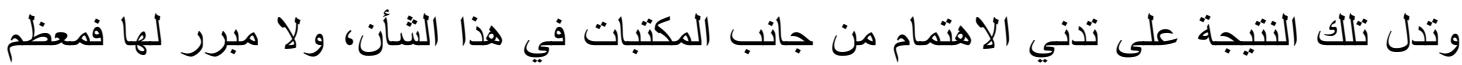

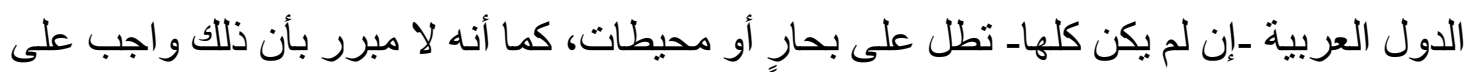
المكتبات التي تقع بالمدن الساحلية، فليس المطلوب من قاطني المدن الساحلية فقط الحفاظ على بلى دان الحياة البحرية؛ فكثيرٌ من سكان المدن غير الساحلية قد ينتقلون بشكلٍ مؤقت أو دائم للعيش في تلك

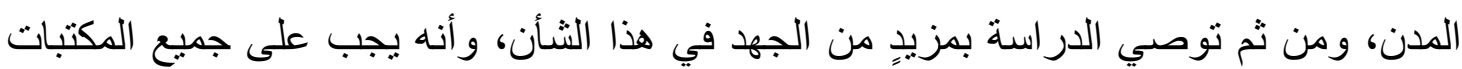
بصفة عامة التو عية بالحفاظ على الحياة البحرية، بغض النظر أكانت بمدينة ساحلية أم لا.

جدوله 1 توزيع جهود المكتبات في الحفاظ على النظام البيئي البحري وفقًا للنوع

\begin{tabular}{|c|c|c|c|c|}
\hline مجموع & 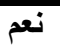 & $\bar{\gamma}$ & نوع & متغير \\
\hline$\Lambda$ & $T$ & 7 & مركزية & التو عية بأهمية البحار و الحفاظ عليها \\
\hline$\Lambda$ & $\cdot$ & $\lambda$ & كلية & \\
\hline 17 & $r$ & $1 \varepsilon$ & & 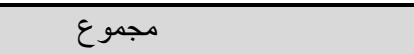 \\
\hline$\Lambda$ & 1 & $\mathrm{~V}$ & 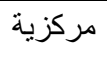 & \multirow{2}{*}{ التوعية بأضر ار الصبد البحري الجائر } \\
\hline$\Lambda$ & $\cdot$ & $\Lambda$ & كلية & \\
\hline 17 & 1 & 10 & & 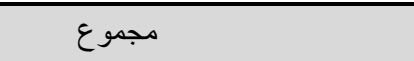 \\
\hline$\Lambda$ & 7 & $r$ & مركزية & \multirow{2}{*}{ لا شيء مما سبق } \\
\hline$\Lambda$ & $\Lambda$ & $\cdot$ & كلية & \\
\hline 17 & $1 \varepsilon$ & 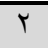 & & مجموع \\
\hline
\end{tabular}

ولم تذكر أي منها أية إضافات يقومون بهاحاليًا، وكذلك لم يضف أي منهم أية مقترحات بجهودٍ يمكن استحداثها بهذا الثأن. 


\section{ه - 1 - حماية النظام البيئي على الأرض:}

أفادت مكتبتان بنسبة (T I\%) - كما يتضح من جدول IV - بقيامهما بالتوعية بالإدارة المستدامة للأر اضي الزر اعية هما: مكتبة الجامعة الأمريكية، ومكتبة جامعة نايف، ونفت البقية

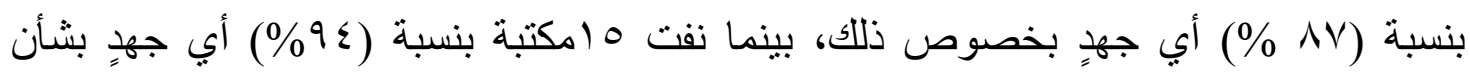

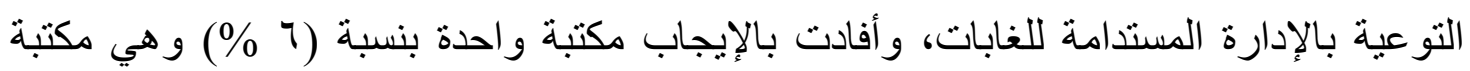
الجامعة الأمريكية، في حين أفادت مكتبتان بنسبة (س \% \%) بقيامهما بالتو عية بالإدارة المستدامة لموارد المياه العذبة وأهمية الحفاظ عليها هما: مكتبة الجامعة الأمريكية، ومكتبة جامعة نايف،

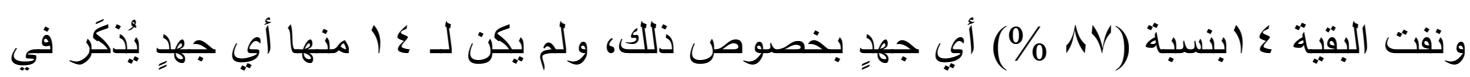
هذا المجال، وتعكس تلك النتيجة و اقعًا سلبيَّا و غير متوقع من دول معظمها يحتوي على مصنادر

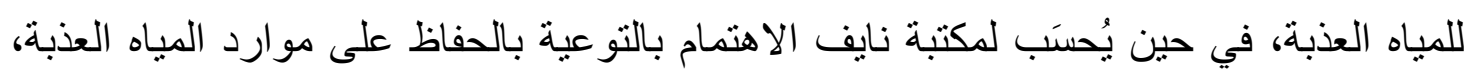

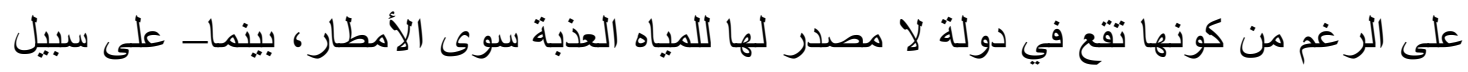
المثال ـ لم تسع أي من المكتبات في مصر صاحبة واحد من أكبر الأنهار في العالم لبذل أي جهٍ في هذا الثأن.

جدول V التوزيع جهود المكتبات في الحفاظ على النظام البيئي على الأرض وفقًا للنوع

\begin{tabular}{|c|c|c|c|c|}
\hline مجموع & نمع & $\bar{\gamma}$ & نوع & متغيز \\
\hline$\wedge$ & r & 7 & مركزية & توعية بالإدارة المستدامة للأر اضي \\
\hline$\Lambda$ & $\cdot$ & $\Lambda$ & كلية & \\
\hline 17 & r & $1 \leqslant$ & & مجموع \\
\hline$\lambda$ & $\begin{array}{r} \\
\end{array}$ & $T$ & مركزية & \multirow{2}{*}{ توعية بالإدارة المستدامة للغابات } \\
\hline$\lambda$ & $\Lambda$ & $\cdot$ & كلية & \\
\hline 17 & 10 & 1 & & مجموع \\
\hline$\wedge$ & $r$ & 7 & مركزية & \multirow{2}{*}{ تو عية بالإدارة المستدامة لمصادر المياه العذبة } \\
\hline$\wedge$ & . & $\wedge$ & كلية & \\
\hline 17 & r & $1 \leqslant$ & & مجموع \\
\hline$\Lambda$ & 7 & r & مركزية & \multirow{2}{*}{ لا شيء مما سبق } \\
\hline$\Lambda$ & $\Lambda$ & $\cdot$ & كلية & \\
\hline 17 & $1 \varepsilon$ & r & & مجموع \\
\hline
\end{tabular}

ولم تذكر أي منها أية إضافات يقومون بهاحاليًا، وكذلك لم يضف أي منها أية مقترحاتٍ بجهودٍ يمكن استحداثها بهذا الثأن. 


\section{1 ـ تعزيز المجتمعات السلمية والثاملة:}

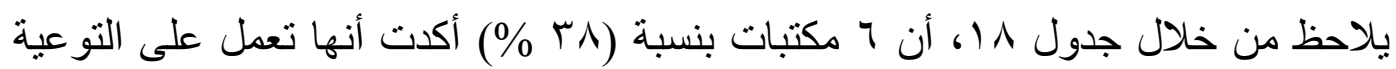
بأهمية الر أي و الرأي الآخر، وهي: مكتبة جامعة الأهر ام الكندية، ومكتبة جامعة نايف، ومكتبة كلية الفنون الجميلة بالجامعة اللبنانية، و المكتبة المركزية بجامعة القاهرة، والمكية والمكتبة المركزية

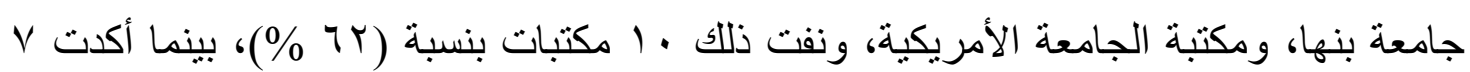

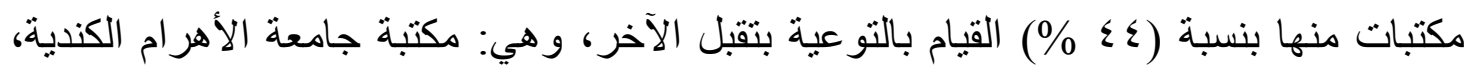

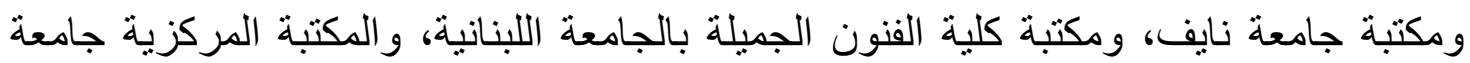

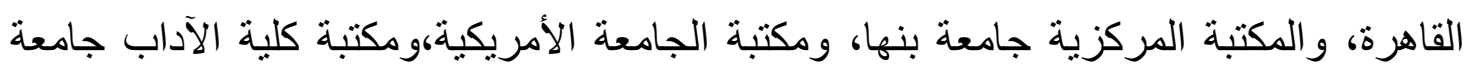

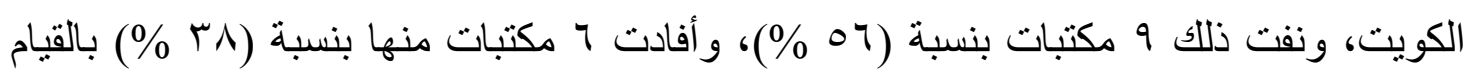

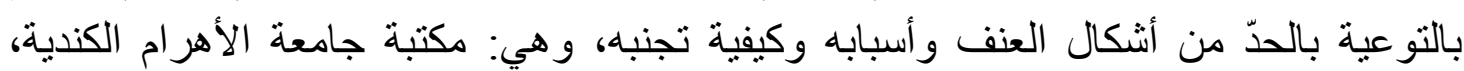

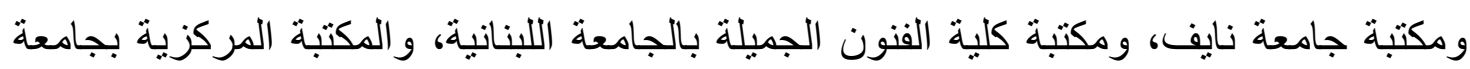

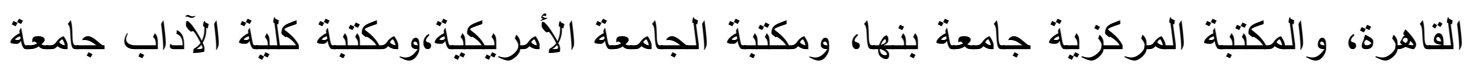
الكويت، و نفت ذلك • 1 (مكتبات بنسبة (r7 \%)، في حين أكدت ع مكتبات الاهتمام بالتوعية بثقافة السلامهو هي: مكتبة جامعة الأهر ام الكندية، ومكتبة جامعة نايف، ومكتبة كلية الفنون الجميلة

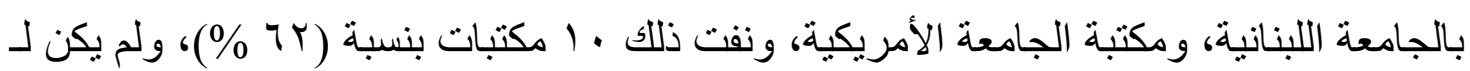

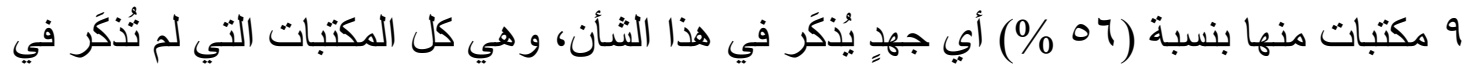
الجهود الفرعية السابقة بهذه الفقرة، وتحتاج المكتبات لتطوير الأداء في المحور إلى إعادة صياغة فئة للأنشطة و الخدمات التي تقدمها.

جدوله ا توزيع جهود المكتبات في تعزيز المجتمعات السلمية والثاملة وفقًا للنوع

\begin{tabular}{|c|c|c|c|c|}
\hline مجموع & ن ن نمم & $\bar{y}$ & نوع & متغير \\
\hline$\Lambda$ & 0 & $r$ & مركزية & التو عية بحرية الر أي \\
\hline$\Lambda$ & 1 & $\bar{V}$ & كلية & \\
\hline 17 & 7 & 1 . & & مجموع \\
\hline$\wedge$ & 0 & $r$ & 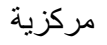 & \multirow{2}{*}{ التو عية بتقبل الاخر } \\
\hline$\Lambda$ & T & 7 & كلية & \\
\hline 17 & V & 9 & & مجموع \\
\hline$\lambda$ & $\varepsilon$ & $\varepsilon$ & مركزية & \multirow{2}{*}{ التو عية بنبذ العنف ومسبباته } \\
\hline$\Lambda$ & r & 7 & كلية & \\
\hline 17 & 7 & $1 \cdot$ & & مجموع \\
\hline$\Lambda$ & $r$ & 0 & 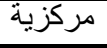 & \multirow{2}{*}{ التوعية ونشر ثقافة السلام } \\
\hline$\wedge$ & 1 & V & كلية & \\
\hline 17 & $\varepsilon$ & TT & & مجموع \\
\hline$\Lambda$ & $r$ & 0 & مركزية & \multirow{2}{*}{ لا شيء مما سبق } \\
\hline$\Lambda$ & 7 & T & كلية & \\
\hline 17 & 9 & $\bar{V}$ & & مجموع \\
\hline
\end{tabular}


ولم تذكر أي منها أية إضافات يقومون بها حاليًا، وكذللك لم يضف أي منهم أية مقترحاتٍ بجهودٍ يمكن استحداثها بهذا الثأن. V ا ـ تعزيز الشراكة العالمية:

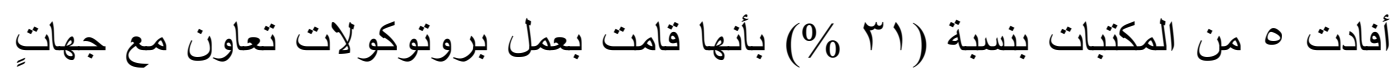

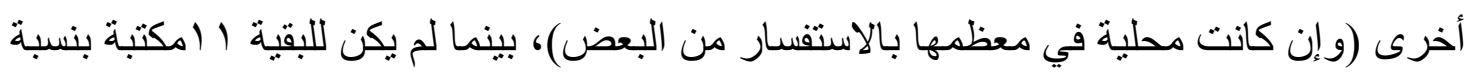

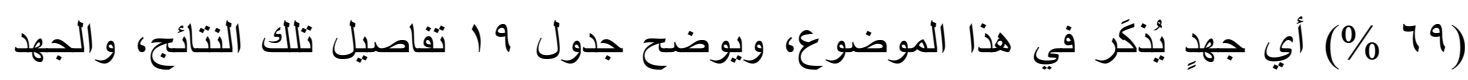

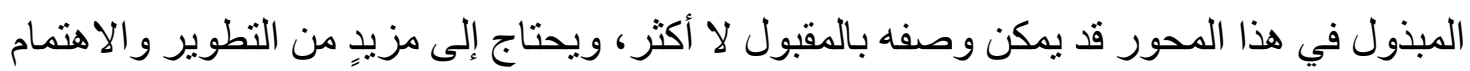
من جانب المكتبات، والانتقال من التركيز على عقد الاتفاقيات المحلية إلى عقد اتفاقيات دولية.

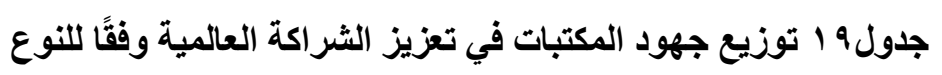

\begin{tabular}{|c|c|c|c|c|}
\hline مجموع & 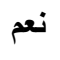 & ע & نوع & متغير \\
\hline$\Lambda$ & $\varepsilon$ & $\varepsilon$ & مركزية & اعداد اتفاقيات \\
\hline$\lambda$ & $T$ & V & كلية & \\
\hline 17 & 0 & 11 & \multicolumn{2}{|c|}{ مجموع } \\
\hline$\wedge$ & $\varepsilon$ & $\varepsilon$ & مركزية & \multirow{2}{*}{ لا شيء مما سبق } \\
\hline$\wedge$ & V & 1 & كلية & \\
\hline 17 & 11 & 0 & \multicolumn{2}{|c|}{ مجموع } \\
\hline
\end{tabular}

ولم تذكر أي منها أية إضافات يقومون بها حاليًا، وكذلك لم يضف أي منهم أية مقترحاتٍ بجهودٍ يمكن استحداثها بهذا الثأن.

وبناءً على ما سبق من جميع نتائج المحاور الـ V اللتنمية المستدامة في المكتبات الأكاديمية

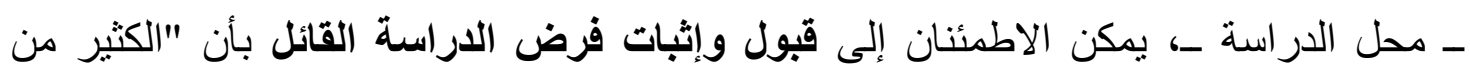

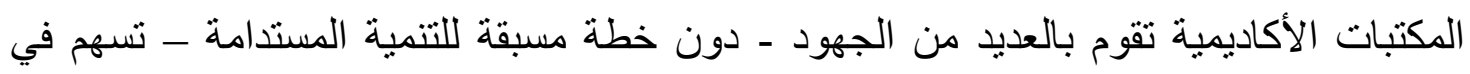

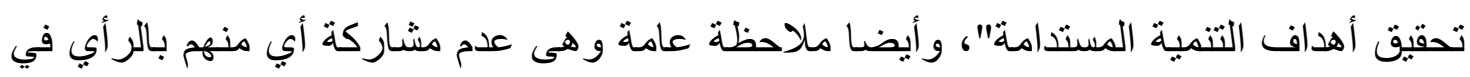
استحداث أي أنشطة على مدار جميع محاور التنمية المستدامة.

تقييم المكتبات وفقًال "مقياس جهود التنمية المستدامة في المكتبات

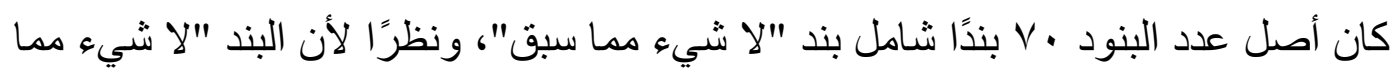

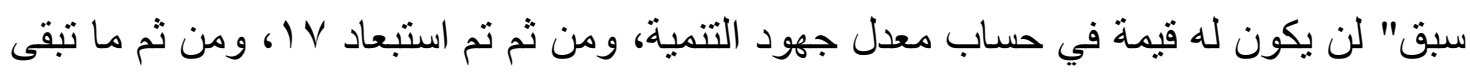


بعد ذلك هو به بنداً هيما تم استخدامها في المقياس، وقد تم تحويل الإجابات إلى قيم رقمية، بحيث تكون القيمة واحد تعني الإيجاب و القيمة صفر تعني النفي. ووفقًا للنتائج يمكن توزيع المكتبات على ثلاث فئات: مكتبات حصلت على درجات تتر اوح

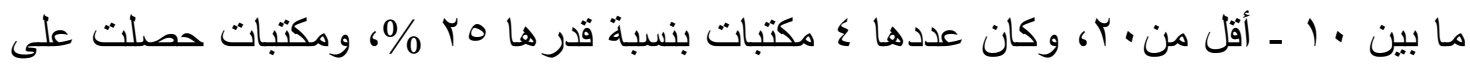

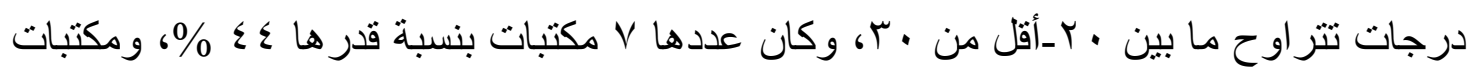

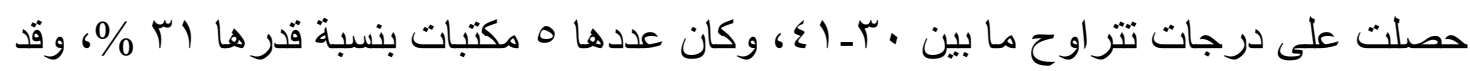

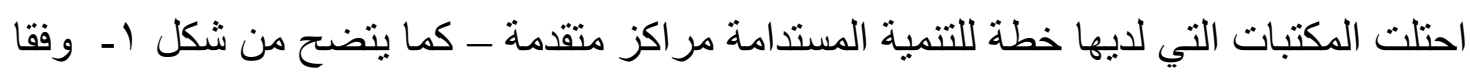
لمقياس جهود التنمية المستدامة، وكانت مكتبة الجامعة الأمريكية في المقدمة، واحتلت المكتبة المركزية لجامعة القاهرة المركز الثاني، وتذيلت القائمة مكتبة المعهد العالي للموسيقى العربية، و تشير تلك النتيجة إلى أنه على المكتبات التي حصلت على تقييمٍ متوسط وتقبيمٍٍ منخفض، تطوير أدائهم بما يتلائم مع دعم تحقيق أهداف التنمية المستدامة، و على الحاصلين على تقييمٍٍ مرتفع البناء على ما يقومون به حاليًا،تتويجه بإعداد خطة للتنمية المستدامة، و وعلى مَن لديهم خطة حاليا السعي

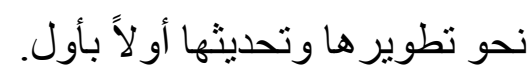

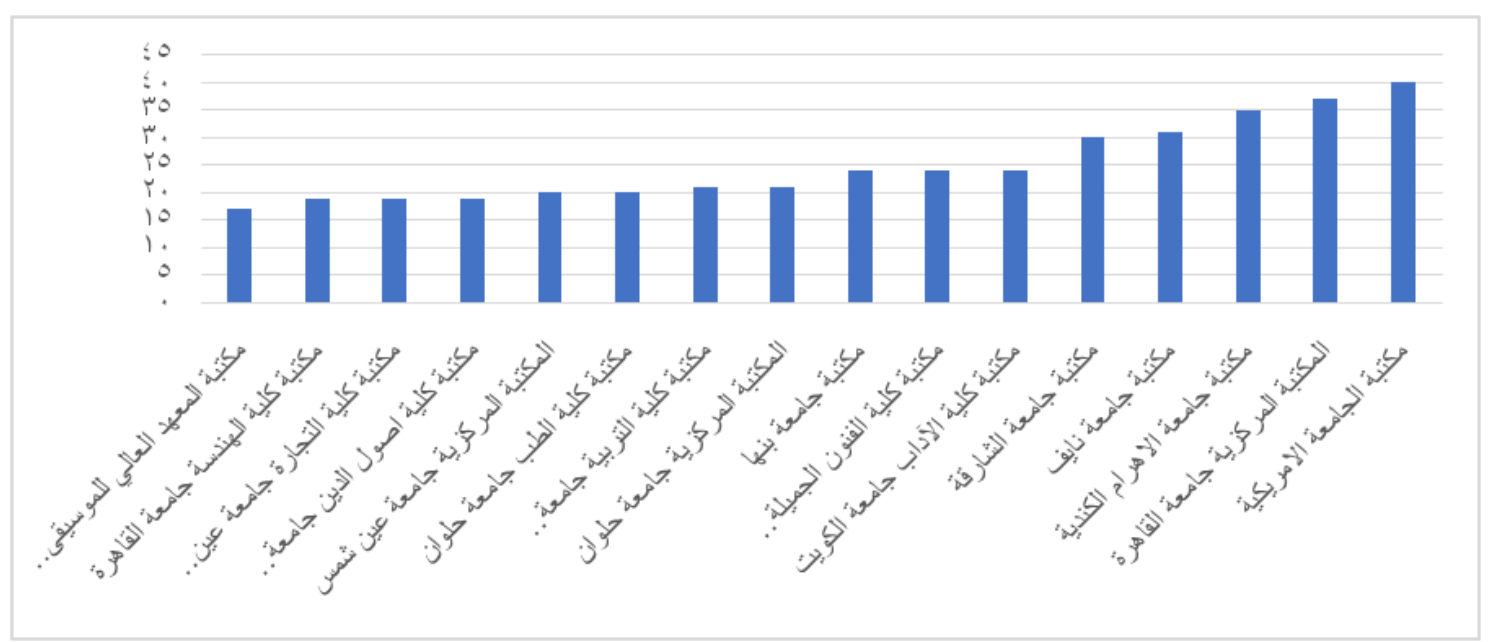

شكل ا ترتيب المكتبات الأكاديمية وفقاً لمقياس جهود التنمية المستدامة

وبناءً على ما سبق، فقد توزعت المكتبات ـ محل الدراسةـ ـ على فئات ثناث: مرتفعة، و متوسطة، وضعيفة الأداء، وفي حال رسمت إحصائيًا فإنها تعطي الرسم الجرسي الطبيعي الذي يقل فيه أصحاب الأداء المثالي، ويتوزع على جانبيه أصحاب الأداء المتوسط و الضعيف، ومنطقيَّا هذه النتيجة ليست بمستغربة، فمنطقيَّا يتوقع أن تكون المكتبات التي لديها خطة للتنمية المستدامة 
في المقدمة؛لأنها تفعل ما تفعله بوعي،فهى تعرف ماذا تقدم من خدماتٍ وأي أهداف تسعى لتحقيقها من خلال تللك الخدمات، أما ظهور مكتبة لم يكن لديها خطة للتنمية المستدامة في المر اكز المتقدمة (المكتبة المركزية لجامعة القاهرة)، فيمكن تفسير ذلك من خلال أن هذه المكتبة لها طبيعة خاصة، وهى أن مديريها المتعاقبين منذ إنشائها وحتى الآن يكون أستاذًا من قسم المكتبات جامعة فهنة القاهرة، وهم بطبيعة الحال باحثّون في المقام الأول،وهم أكثر الناس احتكاكًا بالمستجدات على الانى الساحة العلمية في التخصص من أبحاثٍ، وندواتٍ، مؤتمرات ... إلخ، وبالطبع بسعى أي منهم لتطوير أداء المكتبة وفقًالما يستجد من تطورات على الساحة - و وإن فات عليهم وضع خطة للتنمية المستدامةـ ومن ثم قامو ابتطوير أداء المكتبة لتقوم بأغلب ما يمكن أن بُطلَب من أي مكتبة لتحقيق التنمية المستدامة لمجتمع المستفيدين منها، وهو ما يؤكد قول أن الإرادة و الرغبة في التنفيذ قد تكون أقوى من القانون نفسه، بمعنى أنه قد يكون هنالك قانون و لا أحد ينفذه، وقد لا يكون هناك

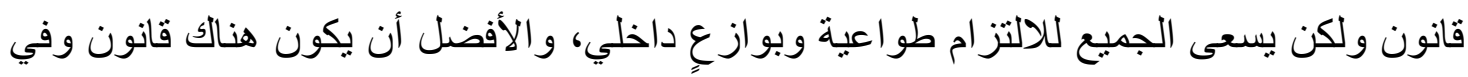
نفس الوقت يسعى الجميع للالتز ام طو اعية وبوازعٍ داخلي؛ لأن في الحالة الأخيرة سيقوم كل فردٍ بما عليه بوعي؛ فهو يعلم لماذا يقوم بهذا العمل، وماهو الهدف أو الأهداف المرجو تحقيقها من ون

ذلك.

و النتيجة السابقة تدفع نحو التحقق من فرض الاراسة القائل بأن "هناك علاقة بين نوع

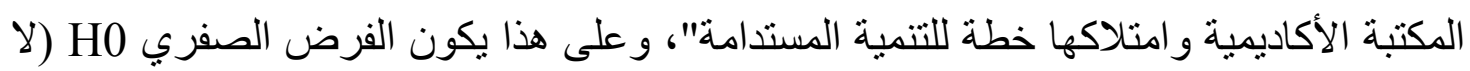

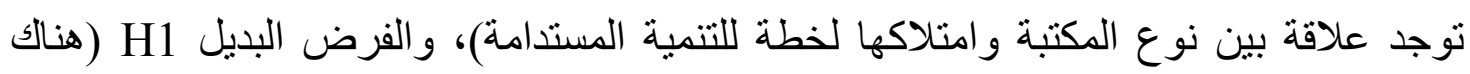

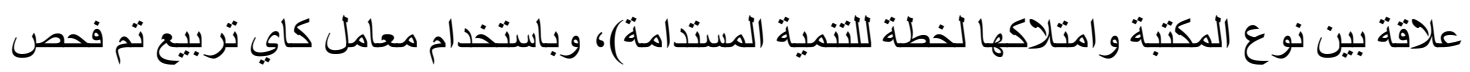
العلاقة بين متغير نوع المكتبة (مكتبة جامعة - مكتبة كلية) ومتغير وجود خطة للتنمية

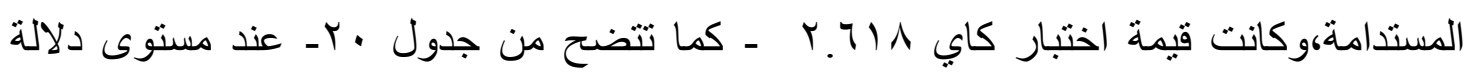

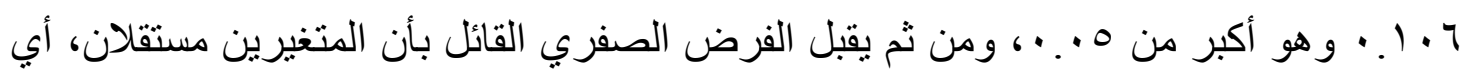
ليس بينهما علاقة، ويبر هن على تلك النتيجة حصول إحدى المكتبات التي ليس لديها خطة للتنمية المستدامة على مركزٍ متقدمٍ وفقا لمقياس جهود التنمية المستدامة في المكتبات.

جدول • r اختبار كاي لفحص العلاقة بين نوع المكتبة وامتلاكها لخطة تنمية مستدامة

\begin{tabular}{|c|c|c|c|}
\hline \multicolumn{4}{|c|}{ Chi-Square Test } \\
\hline & Value & Df & $\begin{array}{c}\text { Asymptotic Significance } \\
\text { (2-sided) }\end{array}$ \\
\hline Pearson Chi-Square & r.Tा^ & 1 & 1.7. \\
\hline
\end{tabular}


أولاً. توصي الدراسة المكتبات الأكاديميةــ محل الار استة بصفة خاصة، والمكتبات على اختلاف

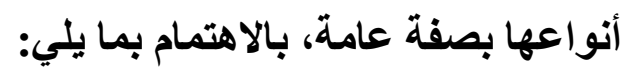

ا إعداد خطة للتمية المستدامة.

r. البدء في تتفيذ و /أو بذل مزيدٍٍ من الجهد التوعوي من فعالياتٍ وأنشطة بخصوص جميع محاور التنمية المستدامة السبعة عشر بصفة عامة؛ للوصول إلى مستوى أداء مرتفع جدًا و فقًا لـ "مقياس جهود التنمية المستدامة في المكتبات"، مع التركيز بصفة خاصة على ما

أ. توفير تدريبٍ حرفي ومهني لمجتمع المستفيدين من الطلاب كأداة لهم على اكتساب المال إلى جانب الثهادة العلمية. ب. توفير دار لر عاية الأطفال لمرتادي المكتبة. ج. نوفير وجبات مجانية للطلاب بالتعاون مع إدارة الجامعة.

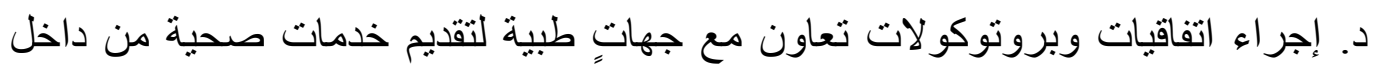
المكتبة، بجانب الاهتمام بالتو عية الصحية. هـ ـ التو عية بالمساو اة بين الجنسين.

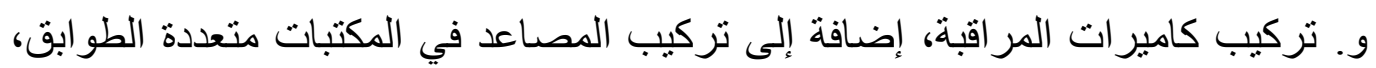
و إعداد منحدر ات الصعود و الهبوط. ز. الاهتمام بالتوعية بأهمية الحياة البحرية والحفاظ عليها، بغض النظر أكانت المكتبة في

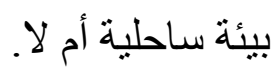

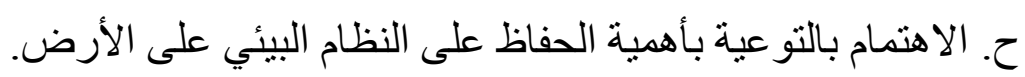
ط. تعزيز المجتمعات السلمية و الثاملة.

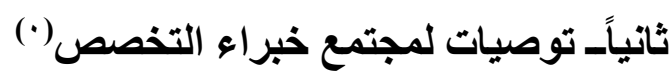
ا ـ تبني استخدام مصطلح - وفقًا للأدو ار و المهام الجديدة للمكتبة ـ "مركز للتنمية الثاملة" أو

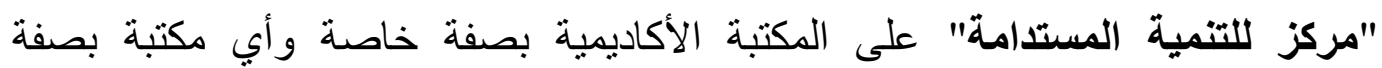
عامة،يساهم بشكلٍ فعَّالٍ في جميع محاور التنمية المستدامة، مع استمر ار اطلاق مصطلح "مكتبة" على المكتبات التي تقدم خدماتها التقليدية دون استهداف محاور التتمية المستدامة. ( •) اقسام المكتبات بالجامعات المختلفة_ مديرو مرافق المعلومات ـ المؤسسات المتخصصة على جميع المستويات... لخ 
ץ. تبني "مقياس جهود التنمية المستدامة في المكتبات خاصة وللمكتبات بصفة عامة؛ لاستخدامه من جانب الباحثين أو القائمين على إدارة المكتبات؛ لتقييم أدائها بشأن جهودها لتحقيق أهداف التتمية المستدامة أو لإرشاد القائمين

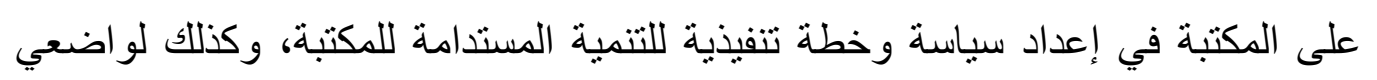
السياسات و الخطط التنفيذية للتنمية المستدامة بالمكتبات على مستوى الدولة.

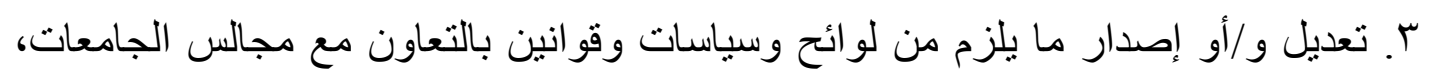

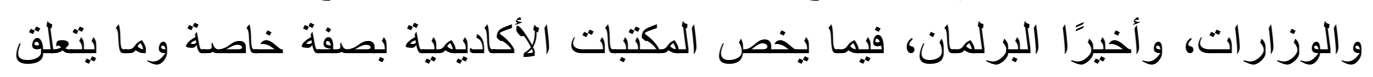
بالمكتبات بصفة عامة،بحسب ما يتتاسب مع كل حالة لتتلاءم مع الأدوار و المهام الجديدة لأي منها.

ع. ير اعى عند تصميم مباني المكتبات الأكاديمية بصفة خاصة، و المكتبات على اختلاف أنو اعها عامة، أن يكون هناك دورات مياه ومصادر مياه ماتهي صالحة للشرب داخل نفس مكان

$$
\text { قاعات الاطلاع. }
$$

ه. يجب إصدار تشريع بأن يتم تصميم وتنفيذ أي مبنى حكومي - بما فيها المكتبات ـ ك "مبنى

إن تحقيق أهداف التنمية المستدامة ليست مههة دولة ولا فرد بعينة، إنما هي مسئوليتنا جميعًا:دول ومنظمات و أفر اد على جميع المستويات، و عليه أصبح الجميع شركاء في المسئوليات

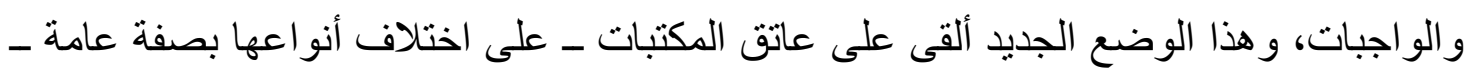

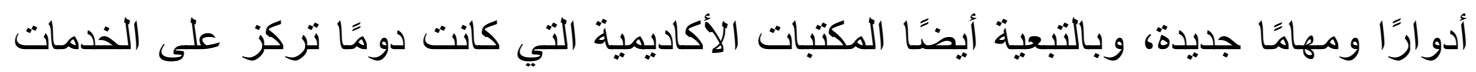

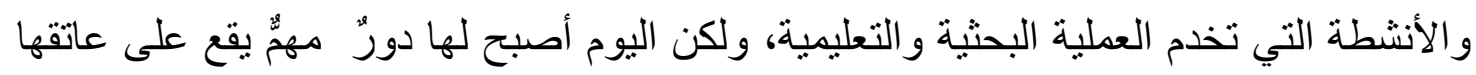

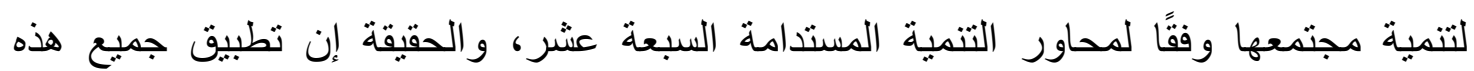
المحاور في المكتبات لبس بالصعب؛ فهنالك أدوات كثيرة يمكن من خلالها تنفيذ هذه الأنشطة

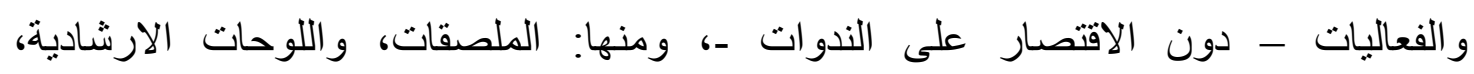

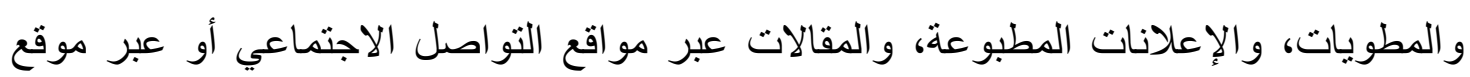
المكتبة... إلخ، فالمشكلة لا تكمن في الأدوات ولكن تكمن في طريقة التفكير و الإدارة، ومن خلال ولاتل هدف الدراسة، وهو رصد وتحليل دور المكتبات الجامعية بمصر في دعم أهداف التنمية

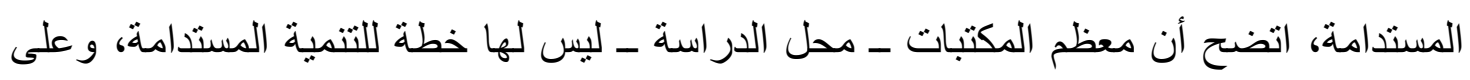
الرغم من ذلك فإنها تقوم بالعديد من الأنشطة التي تسهم في تحقيقها، و إن كانت تحتاج إلى أداء ذلك في ضوء خطة؛ حتى تتم هذه الأنشطة بشكلٍ أكثر فعالية، وحتى يمكنهم تطوير أدائهم أولًا بأول، من خلال تحديث تلك الخطة، وقد لوحظ مدى إيجابية المكتبات المركزية (مكتبات 
الجامعات) عن مكتبات الكليات، وربما هو منطقي بعض الثيء ويعكس الواقع؛ فعادة تكون ميز انية المكتبة المركزية أكبر، كما قد تكون هي مَن يتحكم أيضًا في توزيع ميزانيات ونيات مكتبات

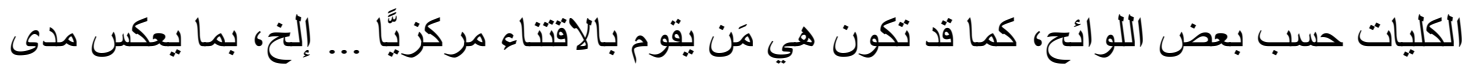

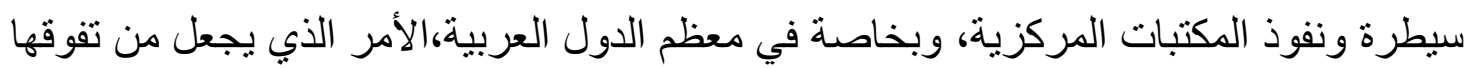
على مكتبات الكليات أمرًا طبيعيًا،وقد قدمت الدراسة الحالية صورة للحالة الردات اهنة بالمكتبات الأكاديمية بشأن جهودها في إطار التنمية المستدامة، إضافة إلى الأداة التطبيقية "مقياس جهود

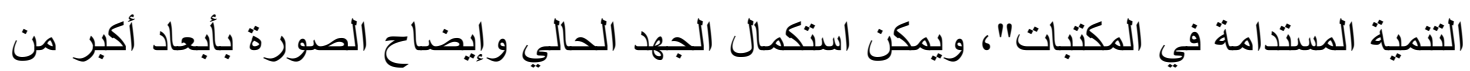

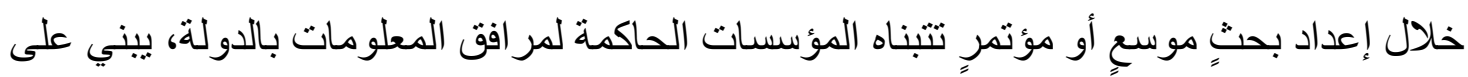
نتائج الدر اسة الحالية و أداتها التطبيقية المشار إليها لإعداد سياسة وطنية وخطط تنفيذية يمكن

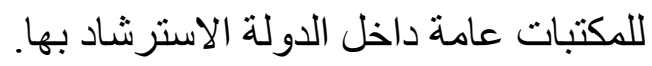

المصادر

Bawack, R. (2018). Academic Libraries in Cameroon: Achieving Agenda 2030 Goals. International Information \& Library Review, 50(1), 63-66.

Churchill, G. (1979). A paradigm for developing better measures of marketing constructs. journal of marketing Research, 16(2), 64-73.

Ezeani, C., Ukwoma, S., Gani, E., Igwe, P., \& Agunwamba, C. (2017). Towards Sustainable Development Goals: What Role for Academic Libraries in Nigeria in Assuring Inclusive Access to Information for Learners with Special Needs? IFLA WLIC 2017 - Libraries. Solidarity. Society. Wrocław, Poland: IFLA.

أحمد الرفاعي غنيم، و نصر محمود صبري. ( . . . ب). التحليل الإحصائي باستخدام برنامج Spss. القاهرة: دار

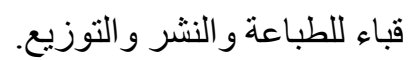
الأمم المتحدة. (ץ • ع .، 9 ( • ؟). الأهداف الإنمائية للألفية التابعة للأمم المتحدة. تم الاسترداد من موقع الأمح

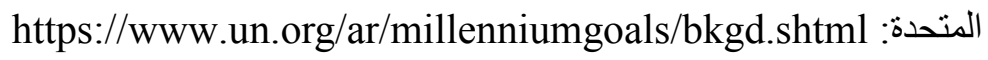

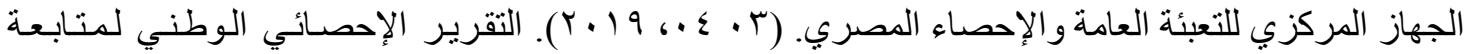

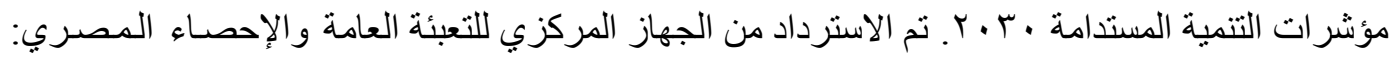
https://capmas.gov.eg/pdf/SDG.pdf

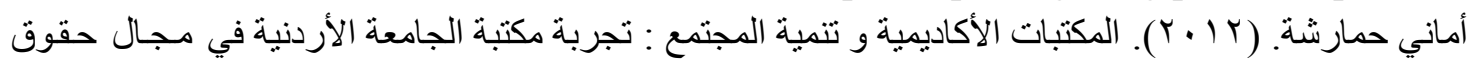

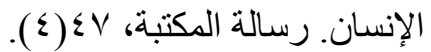

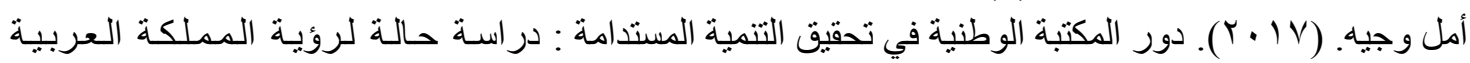

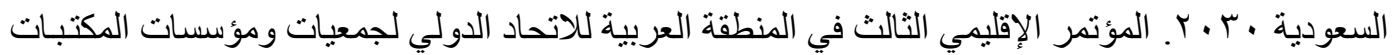

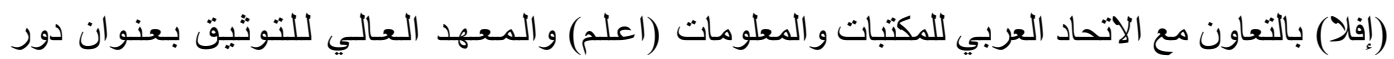

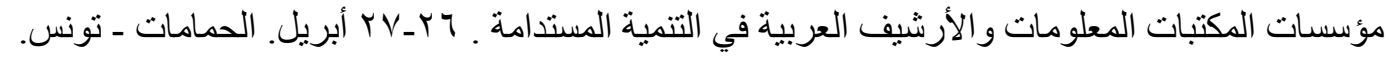

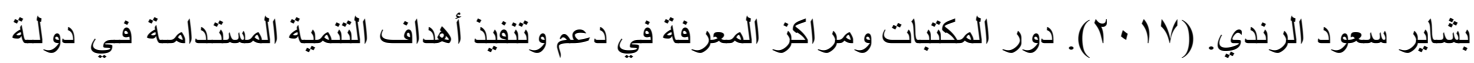


الكويت. المؤتمر الإقليمي الثالث في المنطقة العربية للاتحاد الدولي لجمعيات ومؤسسات المكتبات (إفلا)

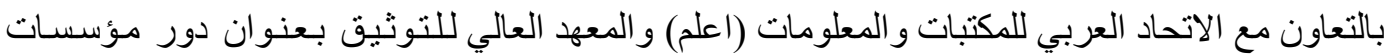

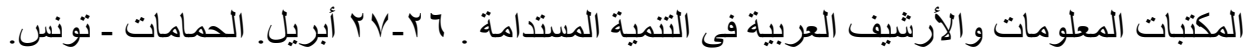

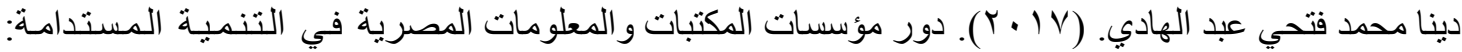

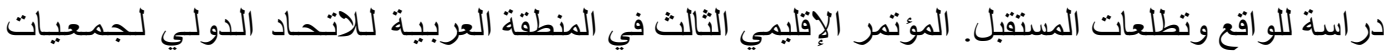

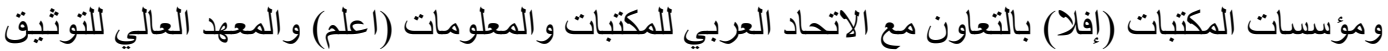

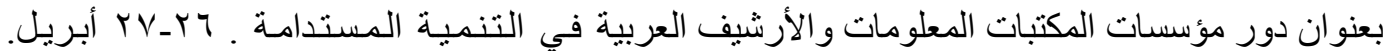
الحمامات - تونس.

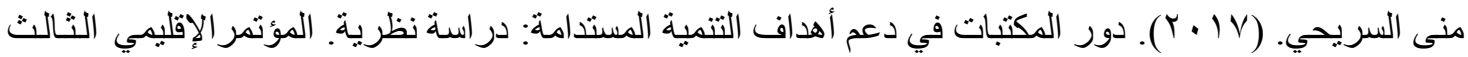

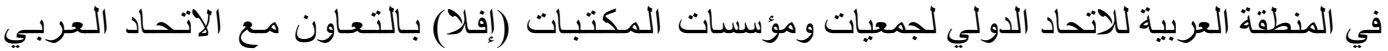

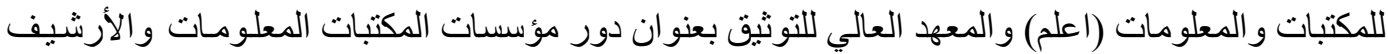

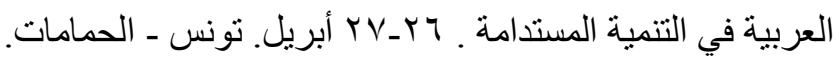

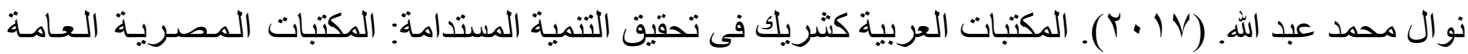

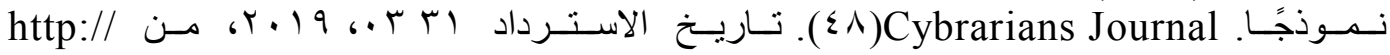
$\left.\mathrm{id}=\lambda r^{\prime}\right): \& v i e w=$ article \&journal.cybrarians.info/index.php?option=com_content Itemid $=9 r \&$ catid $=r 17$ :papers\&nawalabdullah 
مرفق (1)

\begin{tabular}{|c|c|c|c|}
\hline $\mathbf{v 3}$ & $\mathbf{v 2}$ & $\mathbf{v 1}$ & بنود الاستبيان/المقياس(·) \\
\hline & & & خطة للتنمية المستدامة \\
\hline & - & & إعداد خطة للتنمية المستدامة \\
\hline & & & القضاء على الفقر \\
\hline & & - & وصول مجاني لمصادر المعلومات \\
\hline & & - & وصول غير مجاني لمصادر المعلومات \\
\hline & & - & 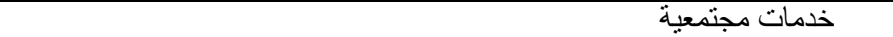 \\
\hline & & - & رعاية الأطفال (حضانة) \\
\hline & & • & تدريب مهني (المحاسبة - مندوب مبيعات - ... إلخ) \\
\hline & & - & تدريب حرفي (سباكة - نجارة - ... إلخ) \\
\hline & - & - & تدريب على مهار ات تكنولوجيا المعلومات \\
\hline - & & & الإسهام في جهود جمع التبر عات وجهود التوزيع على المستحقين \\
\hline - & & & التو عية بكيفية إعداد در اسات الجدوى لإقامة المشرو عات \\
\hline & & & 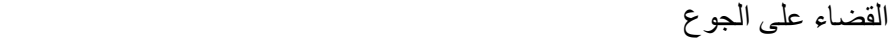 \\
\hline & & - & بشكل غير مباثر/أدلة بالأماكن التي تقدم طعامًا صحيًّا ورخيصًا \\
\hline & & - & بشكل مباشر/تقديم وجبات مجانية \\
\hline - & & & 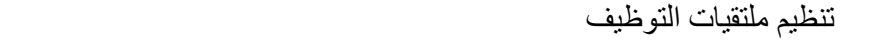 \\
\hline & & & الصحة الجيدة والرفاهية \\
\hline & & - & 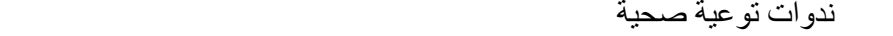 \\
\hline & & - & تقديم خدمات طبية بالتعاون مع الجهات المختلفة \\
\hline & & & 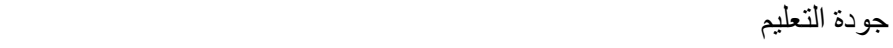 \\
\hline & & - & تقديم دور ات محو الامية \\
\hline
\end{tabular}

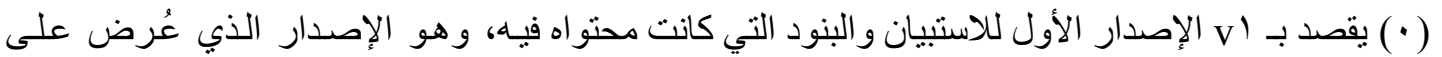

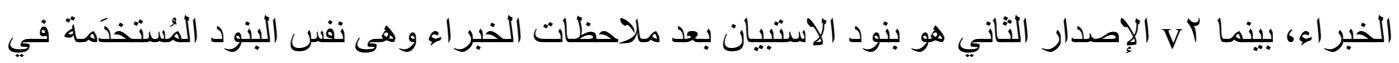

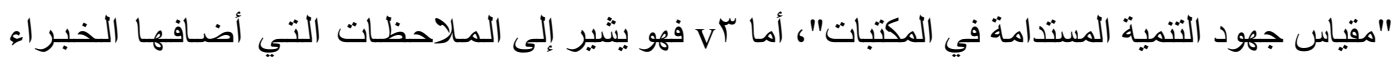

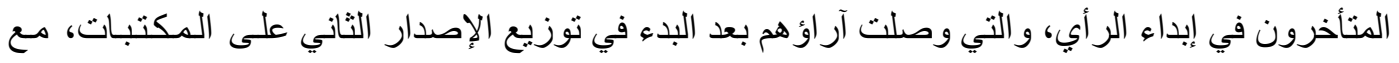

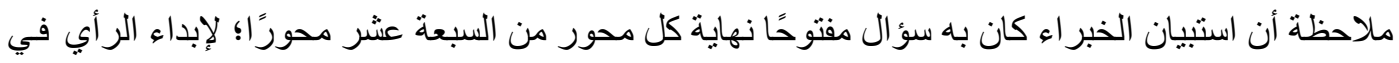

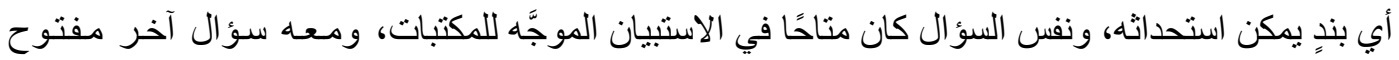

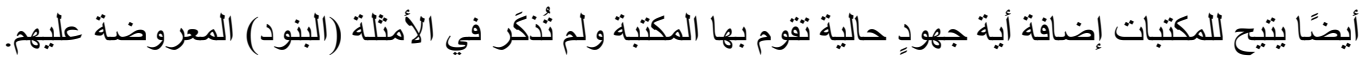




\begin{tabular}{|c|c|c|}
\hline & - & دروس تقوية لجميع المر احل التعليمية \\
\hline \multirow[t]{3}{*}{$\bullet$} & & عقد لقاءات ومحاضر ات تدعم بر امج التدريس بالجامعة \\
\hline & & المساو اة بين الجنسين: الجنين \\
\hline & $\bullet$ & تقدم الخدمات دون تمييز \\
\hline \multirow[t]{7}{*}{ - } & • & تقديم ندو ات حول المساو اة وعدم التمييز \\
\hline & & التو عية بالنماذج الر ائدة من النساء و الرجال في جميع المجالات \\
\hline & & الحصول على مياه نظيفة وصرف صحي \\
\hline & • & توفير دورات مياه صحية \\
\hline & $\bullet$ & توفير مصادر مياه للشرب \\
\hline & $\bullet$ & تو عية بأهمية المياه و عدم الاسر اف فيها \\
\hline & $\bullet$ & توعية بأهمية وجود صرف صحي بالمنزل \\
\hline \multirow[t]{6}{*}{$\bullet$} & & استخدام صنابير آلية تفتح وتغلق بناء على حساس إلكتروني \\
\hline & & طاقة نظيفة وبأسعار زهيدة \\
\hline & - & توفير مصدر طاقة مجانية لثحن أجهزتهم \\
\hline & - & تستخدم المكتبة لمبات نيون \\
\hline & $\bullet$ & تستخلم المكتبة لمبات ليد \\
\hline & $\bullet$ & التو عية بأهمية مصادر الطاقة و عدم الإسر اف في استخدامها \\
\hline$\bullet$ & & المبنى يعتمد بشكلٍ أساسي على الإضـاءة الطبيعية لأطول فترة ممكنة من اليوم \\
\hline \multirow[t]{6}{*}{ - } & & استخدام نظم إضـاءة تفتح وتغلق بشكلٍ آلي بناء على حساس إلكتروني بالأشخاص \\
\hline & & الحصول على عمل لائق ودعم النمو الاقتصادي \\
\hline & - & توفير إعلانات عن الوظائف الشاغرة \\
\hline & $\bullet$ & تدريب مهني \\
\hline & $\bullet$ & ت تدريب حرفي \\
\hline & $\bullet$ & تدريب على مهار ات تكنولوجيا المعلومات \\
\hline \multirow[t]{7}{*}{$\bullet$} & & تنظيم ملتقيات التوظيف \\
\hline & & ضمان تو افر بنية تحتية مرنة وتتجيع التصنيع الثامل و الابتكار \\
\hline & $\bullet$ & دعم وتشجيع أصحاب الابتكار ات \\
\hline & $\bullet$ & إقامة ندوات حول أهمية التصنيع والتعليم الصناعي \\
\hline & $\bullet$ & التو عية بأهمية التعليم الصناعي ودوره في تحقيق التنمية المستدامة \\
\hline & & ضمان تكافؤ الفرص \\
\hline & - & توعية حول نبذ السياسات و الممارسات التمييزية \\
\hline
\end{tabular}




\begin{tabular}{|c|c|c|c|}
\hline & & $\bullet$ & توعية حول الدمج الاجتماعي و الاقتصادي و السياسي لجميع فئات المجتمع و أهميته في تحقيق التتمية \\
\hline & & & جعل المدن و المجتمعات العمر انية شاملة وآمنة \\
\hline & & $\bullet$ & ممرات (منحدر ات) صعود و هبوط لذوي الاحتياجات الخاصة \\
\hline & & $\bullet$ & توفير مصعد داخل المبنى \\
\hline & & $\bullet$ & توفير كامير ات مر اقبة \\
\hline & & $\bullet$ & توفير أفر اد امن داخل المبنى \\
\hline & $\bullet$ & & توفير مصادر معلومات لذوي الاحتياجات الخاصة (بر ايل - مو اد سمعية بصرية) \\
\hline & & & ضمان أنماط استهلاك و إنتاج مستدامة \\
\hline & & $\bullet$ & توعية بتقليل النفايات الغذائية \\
\hline & & $\bullet$ & نشر ثقافة التعامل مع النفايات وتدوير ها \\
\hline & & $\bullet$ & استخدام ورق معاد تدويره \\
\hline & & & مكافحة التغير المناخي واثاره \\
\hline & & $\bullet$ & نشر الوعي بكيفية التعامل مع الكوارث الطبيعية \\
\hline & & $\bullet$ & التو عية بأسباب التغير المناخي و اثاره وكيفية المشاركة في مكافحته على المستوى الثخصي \\
\hline & & $\bullet$ & استخدام نظم إضـاءة ذات انبعاثات حرارية منخفضة \\
\hline & & & الحفاظ على المحيطات و البحار و الموارد البحرية واستخدامها \\
\hline & & $\bullet$ & نشر الوعي بأهمية البحار والمحيطات وكيفية الحفاظ عليها \\
\hline & & $\bullet$ & نشر الوعي باضر ار الصيد البحري الجائر \\
\hline & & & 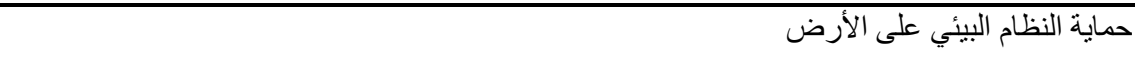 \\
\hline & & $\bullet$ & التو عية بالإدارة المستدامة لمو ارد المياه الطبيعية العذبة \\
\hline & & $\bullet$ & التو عية بالإدارة المستدامة للأر اضي الزر اعية \\
\hline & & $\bullet$ & التو عية بالإدارة المستدامة للغابات \\
\hline & & & تعزيز المجتمعات السلمية والثاملة \\
\hline & & $\bullet$ & نشر الوعي بحرية الر أي و الر أي الآخر \\
\hline & & • & نشر الوعي بثقافة تقبل الآخر \\
\hline & & $\bullet$ & نشر الوعي حول الحذّ من العنف ومسبباته \\
\hline & & $\bullet$ & نشر الوعي حول ثقافة السلام \\
\hline & & & تنشيط الثر اكة العالمية من أجل التنمية \\
\hline & & • & إعداد شر اكات و اتفاقيات إقليمية و عالمية لنقل الخبرات العالمية إلى المكتبة \\
\hline
\end{tabular}

